\title{
Biodiversity, the next challenge for financial institutions?
}

A scoping study to assess exposure of financial institutions to biodiversity business risks and identifying options for business opportunities Ivo Mulder

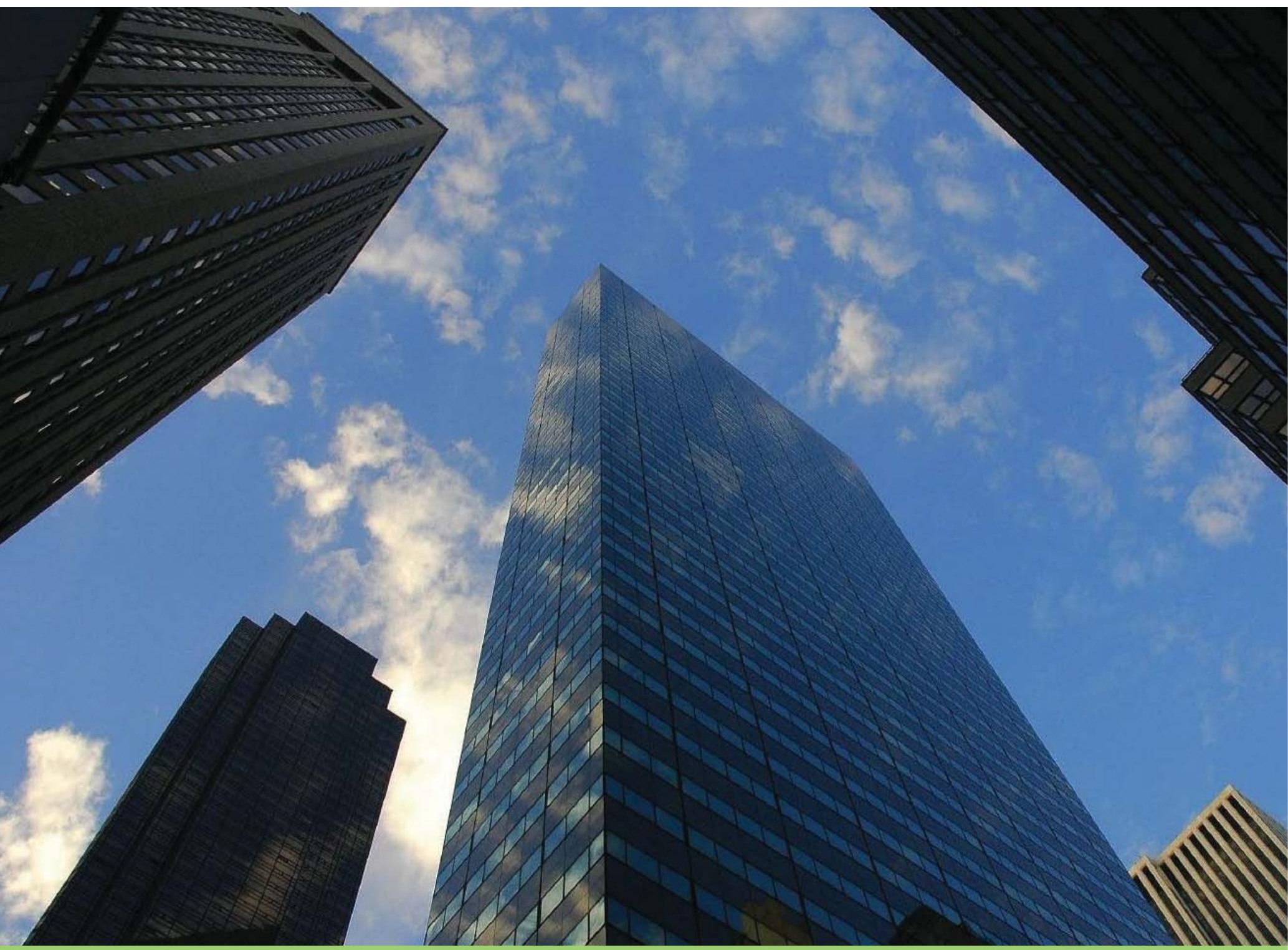




\section{IUCN The World Conservation Union}

Founded in 1948, The World Conservation Union brings together States, government agencies and a diverse range of non-governmental organizations in a unique world partnership: over 1000 members in all, spread across some 140 countries.

As a Union, IUCN seeks to influence, encourage and assist societies throughout the world to conserve the integrity and diversity of nature and to ensure that any use of natural resources is equitable and ecologically sustainable.A central Secretariat coordinates the IUCN Programme and serves the Union membership, representing their views on the world stage and providing them with the strategies, services, scientific knowledge and technical support they need to achieve their goals. Through its six Commissions, IUCN draws together over 10,000 expert volunteers in project teams and action groups, focusing in particular on species and biodiversity conservation and the management of habitats and natural resources. The Union has helped many countries to prepare National Conservation Strategies, and demonstrates the application of its knowledge through the field projects it supervises. Operations are increasingly decentralized and are carried forward by an expanding network of regional and country offices, located principally in developing countries.

The World Conservation Union builds on the strengths of its members, networks and partners to enhance their capacity and to support global alliances to safeguard natural resources at local, regional and global levels. 


\section{Biodiversity, the next challenge for financial institutions?}

A scoping study to assess exposure of financial institutions to biodiversity business risks and identifying options for business opportunities 



\section{Biodiversity, the next challenge for financial institutions?}

A scoping study to assess exposure of financial institutions to biodiversity business risks and identifying options for business opportunities Ivo Mulder 
The designation of geographical entities in this book, and the presentation of the material, do not imply the expression of any opinion whatsoever on the part of IUCN,Alterra, FSD and the Alcoa Foundation concerning the legal status of any country, territory, or area, or of its authorities, or concerning the delimitation of its frontiers or boundaries.

The views expressed in this publication do not necessarily reflect those of IUCN,Alterra, FSD or the Alcoa Foundation.

This publication has been made possible in part by funding from the Alcoa Foundation, Alterra and the IUCN.

Published by: The World Conservation Union (IUCN), Gland, Switzerland in collaboration with Alterra and FSD.

Copyright: @ $\quad 2007$ International Union for Conservation of Nature and Natural Resources

Reproduction of this publication for educational or other non-commercial purposes is authorized without prior written permission from the copyright holder provided the source is fully acknowledged.

Reproduction of this publication for resale or other commercial purposes is prohibited without prior written permission of the copyright holder.

Citation:

Mulder, I. (2007). Biodiversity, the Next Challenge for Financial Institutions? Gland, Switzerland: IUCN. xiv + 60pp.

ISBN-10:

978-2-8317-0994-9

Cover design by: L'IV Com Sàrl

Cover photo: $\quad$ Front $($ C Flickr.com; back $\odot$ stock.xchang

Layout by: L'IV Com Sàrl

Produced by: IUCN Publications Services

Available from: The World Conservation Union (IUCN)

Publications Services

Rue Mauverney 28

1196 Gland

Switzerland

Tel +41229990000

Fax +41229990010

books@iucn.org

www.iucn.org/publications 


\section{Table of contents}

Acronyms

Acknowledgements

Executive summary

1. Introduction

1.1 Why should financial institutions account for biodiversity?

1.2 Project objectives

1.3 Methodology

1.4 Audience

1.5 Key definitions

1.6 Structure of the report

2. Biodiversity loss: a growing relevance for the private sector

2.1 Direct drivers of biodiversity loss

2.2 Indirect drivers of biodiversity loss

2.3 Trends and estimates for future biodiversity loss

2.4 Translating biodiversity loss into business risks and opportunities

3.The business case for biodiversity for financial institutions from a risk perspective 9

3.1 The relationship between ecosystems and the financial sector 9

3.2 Types of biodiversity business risks that financial institutions can be exposed to 10

3.3 Evidence of biodiversity business risks for financial institutions 11

3.3.1 Liability risks 11

3.3.2 Legal and social license to operate 13

3.3.3 Reduced shareholder value 13

3.3.3.1 Evidence of positive performances

3.3.3.2 Evidence of negative performances 14

3.3.4 Reputational risk 14

3.4 How do these drivers for biodiversity risk add up?

4.Assessing biodiversity business risks for commercial banks, asset managers and insurers 19

4.1 Biodiversity risks can differ within the financial sector 19

4.2 Commercial and retail banking 19

4.2.1 Environmental risk management by commercial banks 19

4.2.2 How can commercial banks be exposed to biodiversity risks? 20

4.2.3 Has biodiversity appeared on the radar screen of the commercial banking sector? 21

4.3 Asset management

4.3.1 Environmental risk assessment by asset managers 27

4.3.2 How can asset managers be exposed to biodiversity risks? 29

30

4.4.1 Environmental risk assessment by (re)insurers 30

4.4.2 How can the (re)insurance sector be exposed to biodiversity risks? 30

5.A general procedure to account for biodiversity risks 33

5.1 Financial institution's ability to mitigate biodiversity business risks 33

5.1.1 The ability of commercial banks to mitigate biodiversity business risks 33

5.1.2 The ability of asset managers to mitigate biodiversity business risks 33

5.1.3 The ability of (re)insurance firms to mitigate biodiversity business risks. 33

5.2 A general procedure to account for biodiversity in risk management procedures 33

5.2.1 Identifying important biodiversity areas 34

5.2.2 Tools developed for the private sector that factor-in biodiversity 35

5.2.3 Industry standards and international conventions 35

5.3 Factors contributing to a successful integration of biodiversity into risk management procedures 35

6. Biodiversity business opportunities 41

7. Conclusions 45

8. Recommendations 47

Glossary 
Bibliography

\section{Figures}

Figure 1. Number and percentages of companies with CSR reports in 2002 and 2005

Figure 2. Annual net change in forest area by region 1990-2005 (million ha per year)

Figure 3. Cod landings in tons off the coast of Newfoundland

Figure 4. a.WWF's Living Planet Index (1970-2003) and b. IUCN's Red List Index for birds in different ecosystems (1988-2004)

Figure 5. Estimations of species loss for the past and future

Figure 6. Linking biodiversity loss to business relevance

Figure 7. The dual link between biodiversity and the financial sector:The corporate value chain (impacts on ecosystems) and influences on competitiveness (risks and opportunities)

Figure 8 . The business case for biodiversity from a financial institution's perspective information gathered during interview surveys

Figure 9. The extent to which these actions a source of reputational risk for companies

Figure 10. Average percentage score for engagement with and action on biodiversity

Figure 11. How the Equator Principles have been implemented by a number of corporations in the banking sectorfor the fiscal year 2005 (see also Box VIII)

Figure 12. SRI strategies as applied in Europe (December 31st, 2005; Billion $€$ ),

Figure 13. A general model to account for biodiversity risks in different segments of the financial sector

\section{Tables}

Table 1. Directives and treaties that affect corporate environmental and biodiversity liability risk

Table 2. High risk sectors listed on the FTSE indices according to biodiversity risk exposure

Table 3. Benchmarking of ECRA policies of 10 European banks

Table 4. How different services and products by commercial banks may be prone to biodiversity risks

Table 5. Banks that were covered in the pilot study

Table 6. Integration of biodiversity into the business operations of a number of major banks

Table 7. Trends in SRI in the USA (1995-2005)

Table 8. How different types of investment funds may be prone to biodiversity risks 29

Table 9. The insurability of the risk of biodiversity loss

Table 10. Tools developed for the private sector that focus on or factor-in biodiversity

Table 11. Sector-specific sustainability guidelines, benchmarks and industry bodies

Table 12. Summary of direct and indirect markets for ecosystem services and potential for growth

Table 13. Overview of benchmarks, indexes and other rating agencies and systems that address biodiversity issues within the financial sector 
ABP

ABS

AM

$\mathrm{BBO}$

BiTC

BMP

BBR

CBD

CCX

CDM

CEO

CI

CITES

CFO

CRA

CSE

CSR

DJSGI

EAI

EBI

EBRD

ECRA

EFI

EIA

EMAS

EP

EPFI

ESG

ETS

FAO

FI

FFI

FTSE

GHG

GRI

ICMM

IFC

INCR

IPCC

IPIECA

ISO

IUCN

JI

MA

MIGA

NGO

NTFP

OECD

OFR

PES

RMP

ROI

RSPO

SME

SRI

SRI

SSSI

UNEP FI

VBDO

WCPA

WWF
Associated British Ports

Asset Backed Securitisation

Asset Management

Biodiversity business opportunity (opposite - BBRs)

Business in the Community

Best Management Practice

Biodiversity business risk (opposite - BBOs)

Convention on Biological Diversity

Chicago Climate Exchange

Clean Development Mechanism

Chief Executive Officer

Conservation International

Convention on International Trade in Endangered Species

Chief Finance Officer

Credit Rating Agency

Centre for Science and Environment

Corporate Social Responsibility

Dow Jones Sustainability Group Index

Enhanced Analytics Initiative

Energy and Biodiversity Initiative

European Bank for Reconstruction and Development

Environmental Credit Risk Assessment

Extra Financial Issues

Environmental Impact Assessment

Eco-Management and Audit Scheme

Equator Principles

Equator Principle Financial Institution

Environmental, Social and Governance

EU's Emission Trading Scheme

UN Food and Agriculture Organization

Financial Institution

Fauna \& Flora International

London Stock Exchange (pronounced 'footsie')

Greenhouse gas emissions

Global Reporting Initiative

International Council on Mining and Metals

International Finance Corporation

Investor Network on Climate Risk

Intergovernmental Panel on Climate Change

International Petroleum Industry Environmental Conservation Association

International Organization for Standardization

World Conservation Union

Joint Implementation

Millennium Ecosystem Assessment

Multilateral Investment Guarantee Agency

Non-governmental Organization

Non-timber forest product

Organisation for Economic Co-operation and Development

Operating and Financial Review

Payment for Environmental Services

Risk Management Procedures

Return on Investment

Roundtable on Sustainable Palm Oil

Small and Medium-sized Enterprises

Socially Responsible Investing

Socially Responsible Investing

Sites of Special Scientific Interest (UK)

United Nations Environment Programme - Finance Initiative

Dutch Association of Investors for Sustainable Development

World Commission on Protected Areas

World Wildlife Fund 


\section{Acknowledgements}

Financial support for this work was generously provided by the Alcoa Foundation, through their Alcoa Practitioner Fellowship programme, and by Alterra, a research institute in the Netherlands and part of Wageningen University and Research Centre. The author is indebted to many people who have provided support throughout the project. Foremost, I would like to thank Dr Joshua Bishop, senior advisor Economics \& Environment at IUCN, for his generous and continuous support throughout the entire project. I would also like to thank Herbert Diemont and Gert-Jan Nabuurs for providing financial support for this project, as well as commenting on draft versions.

This report has greatly benefited from helpful comments on the final draft version by Annelisa Grigg of Fauna \& Flora International (FFI), Nicolas Bertrand of the Convention on Biological Diversity (CBD), Wijnand Broer of CREM, Barend van Bergen, KPMG/ WBCSD, and Heidi Mayhew, formerly with UNEP FI.Thank you very much!
Other people who have provided support to this work in various ways include: Mohammad Rafiq, Jeff McNeely, Andrea Athanas, Giulia Carbone, Bhim Adhikari, all IUCN;Assheton Carter, Conservation International; Kerry ten Kate, Forest Trends; Hans Biemans, Rabobank; Josh Knights, The Nature Conservancy; Deric Quaile, Shell; Edgar Rojas, consultant for INCAE; Julien Haarman, formerly with UNEP Finance Initiative; IJs van Leijen, de Vermogensmeesters;Arnold van Vliet and Dolf de Groot, Foundation for Sustainable Development (FSD); and Phillip Kauffmann, formerly with UNDP.

This publication has been made possible by IUCN.The author takes full responsibility of any errors in the text. 

Climate change is now recognized as an important business challenge for a wide range of private sectors. The business case for financial institutions (FIs) to focus on greenhouse gas emissions (GHG) is also getting stronger. FIs that do not understand the business rationale may be at risk when they have invested in, or provided loans, advisory services or insurance products to companies with significant carbon footprints. On the other hand, FIs that understand the issue can capture business opportunities, for example by increasing investments in clean energy technologies or by brokering deals through the European Emissions Trading (ETS) scheme or the voluntary Chicago Climate Exchange (CCX). As an example, Bank of America (BoA) announced on 6 March 2007 a US $\$ 20$ billion initiative to support the growth of environmentally sustainable business activity to address global climate change. And in January 2007 Goldman Sachs announced they have made investments in of US\$1.5 billion in alternative energy/clean technology.

Biodiversity bears characteristics that can lead to it becoming the next challenge for financial institutions (FIs). Global biological resources have decreased by about 30\% since 1970.This has set in motion a number of powerful drivers such as pressure and activism by NGOs, increased regulations such as laws, strengthened liability regimes, scrutiny of a company's supply chain practices and shifting consumer preferences that are leading to a growing relevance of biodiversity to businesses. Certain sectors are more exposed to biodiversity business risks (BBRs) than others. These include:

1. Companies having (high) impacts on ecosystems. These can be subdivided into companies with direct footprints on ecosystems, such as the oil \& gas, mining, and construction, as well as sectors that have significant impacts through their supply chains, such as the food retail sector.

2. Companies depending on ecosystem services. These include for example the tourism, fisheries, forestry and the agricultural sector.

FIs, such as retail and commercial banks, asset managers, private and institutional investors, and insurers that provide financial services to these types of companies can be exposed to BBRs, both directly and indirectly. FIs can be directly exposed to for example reputational risks, liability risk or regulatory scrutiny. As an example, the environment ministers of the G8 countries and the five major newly industrialising countries launched the "Potsdam Initiative - Biological Diversity 2010" on 17 March 2007. The ministers specifically state that they will "approach the financial sector to effectively integrate biodiversity into its decision making".

Indirectly, FIs can be exposed to BBRs for loans and investment portfolios in the above mentioned types of companies.As biodiversity will likely increase in relevance for these types of companies in the coming years, some of them may increasingly come under biodiversity-related scrutiny. Goldman Sachs outlined for example that oil \& gas companies will increasingly explore offshore oil and gas fields, which are more complex for exploration and production, very likely leading to increased BBRs. FIs that are not positioned to identify which companies are most at risk can be exposed to increased risk for default (credit activities), lower investment returns (investment portfolios) or an increase in insurance claims (insurance activities).

This scoping study assessed: 1) what types of BBRs financial institutions can be exposed to; 2) what evidence there is of the biodiversity business case from a financial sector's perspective; 3) what opportunities are available for FIs to address and mitigate BBRs; and 4) what biodiversity business opportunities (BBOs) can be captured by FIs. The key findings are provided below.

\section{Biodiversity business case from a risk perspective}

An interview survey among financial institutions, other private sectors and NGOs revealed that nineteen out of 26 respondents ${ }^{a}$ $(>70 \%)$ believed FIs are exposed to reputational risk. In addition, respondents from the financial sector indicated liability risk, social license to operate, credit risk and reduced shareholder value additional types of risk, although they were seen as less important (at present).

Although it is difficult at present to link BBRs to tangible financial metrics, such as market capitalization, asset value or credit risk, the report provides a wide range of case studies expressing evidence of the business case.This includes for example the case of Associated British Ports, which saw GBP155 million wiped off its market value (about $10 \%$ of its share price) after the UK government blocked the company's plans for a new container terminal at a site in the south of England in April 2004. The government admitted that one major factor in its decision was the potential environmental impact. Although the share price of the company has recovered since, it provides a clear case to investors that extra-financial issues (e.g., biodiversity) make business senses. Another case concerns upcoming liability regulation in the EU.The new EU directive (2004/35/EC) aims at preventing environmental damage to water resources, soil, fauna, flora and natural habitats and at making the polluters pay whenever damage cannot be avoided.This is something the insurance sector will need to respond to in the coming months.

\section{Biodiversity in the business operations of financial institutions at present}

Banking sector. Studies by Oxera and F\&C Asset Management revealed that on a sector-wide level, biodiversity is hardly recognized at present. However, an assessment of 11 commercial and investment banks that were chosen for their global reach and/or involvement in the development and adoption of the Equator Principles, revealed that a considerable number of these banks have already started to go beyond the Equator Principles for project finance to develop sector-specific guidelines. The banks apply these new guidelines to an increasing number of credit products and some investment products. Although these sectorguidelines often do not make reference of biodiversity directly, phrases are used such as tropical moist forest, critical natural habitat or depletion of natural resources, which capture the value of biodiversity to a certain extent.

- Rabobank appears to be the leader on biodiversity, as they are applying a CSR tool as of the 1st of February 2007 to all their lending activities. Three of the ten guiding principles of their CSR tool refer to biodiversity to some extent: 1) environmental pollution; 2) depletion of natural resources; 3) cruelty against animals. They have also developed five types of sectorguidelines and three more are in the pipeline.The bank's client relation managers and risk analysts, who will be the day-to-day users, are obliged to use this tool.

- HSBC and ABN AMRO have also developed multiple sectorspecific policies (e.g., for their forestry clients).

- Goldman Sachs, an investment bank, recently adopted the Biodiversity Benchmark (developed by Fauna \& Flora International and Insight Investment), which they use in their investment decision-making.

\footnotetext{
a Though HSBC did not take part in the interview survey, the company clearly states in their Environmental Risk standard (published in June 2003) what types of biodiversity/environmental risk it can be exposed to.
} 
With respect to identifying which types of credit products are most exposed to BBRs, there are a number of characteristics such as 1) timeline of the loan;2) non-recourse; and 3) loans to companies with high impacts on ecosystems and/or ecosystem dependent sectors, which can all contribute to a greater exposure of credit products to BBRs. This can be the case for project finance or other types of structure finance products, as well as for long term corporate loans. The ability of commercial banks to respond to BBRs would be by means of thorough due diligence work and environmental impact assessment (EIA) that include biodiversity components.Also, constructive dialogues with clients, engagement, are an important means to reduce exposure to BBRs, for example by pointing them to sector-specific best management practices (BMPs).

Asset management. Many fundamental or conventional investors have long considered environmental issues to be a topic simply for the Socially Responsible Investment (SRI) market.This, because SRI markets are associated with investors who are putting environmental and social issues at the forefront of investment decision making (in stead of financial ones) and they are therefore presumed to be satisfied with lower investment returns (ROI). Though prior investment results in the SRI area have been mixed, there is some evidence that incorporating environmental issues can lead to superior portfolio performances compared to similar fundamental funds. Just as for other environmental issues, asset managers can also be exposed to BBRs when companies, in which they hold shares or ownership, deliver poor financial results (partly) caused by biodiversity-related scrutiny.

With respect to identify which types of investment funds are most exposed to BBRs, there are a number of characteristics such as 1) timeline of the fund;2) investments in companies with high impacts on ecosystems and/or ecosystem service dependent companies; 3) climate change leading to less stable natural environments, which can all contribute to a greater exposure of investment portfolios to BBRs. Asset managers have the ability to respond to these risks by means of 1) positive and negative screening during fund initiation; and 2) voting power during shareholder meetings.

(Re)insurance. Traditional types of environmental liability claims included 1) property or liability loss on the basis of sudden or accidental pollution; 2) product liability loss; or 3) property loss during an operational breakdown. However, the (re)insurance sector is facing new types of environmental liability, specifically related to an increase in extreme weather events caused by climate change. Economic losses from crop failure and forest fires alone, for example, accounted for US\$ 14 billion. During 2002, major floods across Europe caused total damage of almost US\$ 16 billion and insured losses of just over US\$ 3 billion. Hurricane Katrina caused prices to rise up to $300-400 \%$ for oil companies in the Gulf of Mexico seeking insurance and insurers seeking reinsurance to protect against offshore losses.

The most noteworthy development for biodiversity for the insurance sector is new legislation in the EU as of 30 April 2007 to hold operators liable for damage to water resources, soil, fauna, flora and natural habitats and at making the polluters pay whenever damage cannot be avoided. Although biodiversity has characteristics that make it difficult to meet conditions for insurability, insurance and reinsurance firms need to respond to this.

\section{Integrating biodiversity in business operations of financial institutions}

For those FIs that understand the materiality of the issue and that want to identify how to integrate biodiversity into their risk management procedures (RMP), thereby mitigating any adverse BBRs, the report outlined a general procedure. The procedure provides an overview of existing tools to:
1) Identify biodiversity important areas. A number of NGOs have developed (spatial) tools that identify important biodiversity areas, although most areas are quite broad. Work is underway at present to develop a biodiversity tool for the private sector that identifies much more in detail where biodiversity hotspots are situated.

2) Identify what tools that have been developed for the private sector that factor-in biodiversity. These can be used by FIs, both in their own RMP or as indicators for their clients to assess their ability to address biodiversity.

3) Identify sector-specific industry guidelines and international conventions. Several FIs indicated during the interview survey that they would greatly benefit by knowing what the bestmanagement practices are sector-by-sector. By knowing this, they can inform their clients, as part of their conditions in issuing contracts or use it in developing sector guidelines.

A number of criteria were identified as well by FIs that would contribute to successfully integrating any biodiversity-related tools in their RMP.These include:

1) It should be easy to use by people working with it on a dayby-day basis, such as client relation managers, risk analysts and fund managers.

2) It needs to be implemented in existing business structures in order not to overburden the credit lending or investment process.

3) It needs to be sector-specific and identify sustainable industry standards (e.g., multilateral conventions, industry guidelines, benchmarks).

4) Ideally any type of tool should be adopted by a wide range of FI thereby creating a level-playing field.

\section{Biodiversity business opportunities}

Although BBRs are likely to be more significant in terms of market value, there are a number of biodiversity business opportunities (BBO) that FIs can capture, especially those that have already started to recognize the materiality of it. These include, but are not limited to:

1) Growing markets for certified sustainable produced commodities, such as for wild fish, aquaculture or agricultural products. Estimates suggest a potential market size of about US\$60 billion annually by 2010 . There are also market opportunities for biodiversity offsets, biocarbon, NTFPs, PES and biofuels among others. Estimates for potential market sizes range widely from US\$ 35 million - 10 billion annually by 2010 .

2) Due diligence or advisory services to clients that need assistance in biodiversity sensitive projects and transactions.

3) Biodiversity-related insurance cover. For example, around 65\% of the insurance premium of the shipping companies using the Panama Canal is environment-related, such as covering for too little water or delays because of regular dredging. Reforestation along the slopes of the canal will drastically cut insurers' exposure to BBRs.

4) Government-induced opportunities. The Dutch government for example triggered demand by private investors to invest in green funds. Total capital invested in 2005 amounted to $€ 1.5$ billion, of which $€ 282$ million has been allocated to the project category "nature, forests and landscapes".

5) Conservation land as a result of default or debt work-out. Should a bank acquire a significant amount of biodiversitysensitive land as a result of default or debt work-out situations, collaborations with NGOs, local conservation organizations, or the government might be helpful in finding suitable (conservation) purposes for the land. While the bank remains owner of the land, it could use the situation to bolster its reputation or for other marketing purposes. 


\section{Moving Ahead.....}

Despite the fact that there is undoubtedly greater interest in biodiversity issues in the financial sector, there is clearly a huge effort needed to continue to build the biodiversity business case and increase the awareness of biodiversity as a significant business factor within the financial sector. The following recommendations can contribute to this:

\section{Continue to build the biodiversity business case for Fls}

1) A Stern-like review $w^{b}$ of the economic costs of biodiversity loss and benefits of biodiversity conservation can lift the issue up the international political and business agenda. The need for such a study was also highlighted during the G8 meeting of environment ministers in Potsdam, March 2007. There is a big role to play here for government agencies, research institutes, as well as for the NGO community.

2) Greater focus on quantifying the business case from a risk perspective. Though this project provided a wide-range of case studies expressing evidence of the business case, it is important to link biodiversity business risks (BBRs) as much as possible to tangible financial metrics, such as default risk, shareholder value or market capitalization, in a systematic way.

3) With respect to biodiversity business opportunities (BBOs), a stronger effort should be undertaken from the NGO community (in collaboration with Fls that are recognizing potential business opportunities) towards identifying BB0s, as well as start pilot projects to assess their financial viability.

\section{Diversify communication \& raise awareness of the materiality of biodiversity to Fls}

4) Diversify the communication channels about the business case for biodiversity to Fls. Governments, multilateral institutions and NGOs as well as those Fls that have already started to address biodiversity are examples of stakeholders that can participate in such a process.

5) Building capacity within Fls to mitigate BBRs and identify BBOs. As this issue is rather new for the sector there is a need for Fls to build capacity to deal with this emerging issue. This can for example be achieved through training of staff, engaging in partnerships with NGOs and multilateral organizations or by hiring consultancies that possess the technical capacity. UNEP FI has already initiated a working stream on the issue.

\section{Develop tools that day-to-day users can use}

6) Biodiversity should be integrated in such a way that it becomes practical by people using such tools on a day-by-day basis. This includes, for example, client relation managers, credit analysts, and fund mangers.

\section{Focus on the entire financial sector}

7) Focus on other segments of the financial sector. This project focused on commercial banking, asset managers/investors and insurance. In an effort to increase awareness throughout the entire sector, there is a business rationale to include other segments of the financial sector as well.

- Though this study focused on (institutional) investors to a certain extent, there is a clear need to increase the focus on this segment of the financial sector. Due to the long term horizons of their investments, pension funds, insurance firms, and other institutional investors have a clear business rationale to incorporate biodiversity into their risk management procedures and investment decision-making.

- Similar efforts should be made to engage credit rating agencies in this process, by identifying possibilities to incorporate biodiversity into the "credit-worthiness" assessments for projects, companies, and countries.

- Since biodiversity is often still regarded as a public good, governments, which control huge amounts of public bonds and public pensions, even have a special obligation to assess possibilities to integrate biodiversity into their risk management procedures and investment decision-making. 


\section{Introduction}

On 17 March 2007 the environment ministers of the G8 countries and the five major newly industrializing countries launched the "Potsdam Initiative - Biological Diversity 2010". This initiative will set in motion a number of activities for the protection and sustainable use of biodiversity. The ministers specifically state that they will "approach the financial sector to effectively integrate biodiversity into its decision making". ${ }^{1}$

This is one example in a growing body of evidence that new regulations and legislation, shifting consumer preferences, activism by NGOs, increased dependency by companies on ecosystem services and scrutiny of supply chains ${ }^{2}$ are among the key drivers leading to increased business relevance of biodiversity for companies. Companies increasingly acknowledge that their business activities bear a significant impact on the environment and ecosystems and that they hold a social and environmental responsibility. Responsibility is not only reflected in moral obligations as "to do something good for the environment", it is increasingly reflected in business matters.

So far, attention has been mainly focused on those sectors that either have a direct high footprint on ecosystems (thus on biodiversity), such as the oil \& gas, the mining and utilities sectors, or sectors that are dependent on ecosystem services, such as the tourism, agribusiness, forestry and fisheries sectors. As a consequence, industry bodies have emerged, such as the International Council on Mining and Metals (ICMM) in $2001^{c}$ for the mining \& metals sector and the International Petroleum Industry Environmental

\section{Box I. The magnitude of the financial sector}

The financial sector, being one of the largest sectors in the world, grew considerably in the last four years, from about US\$ 37 trillion in 2001 to reaching US\$ 49 trillion in total assets by 2005 . The banking sector, being the largest sector in the financial services sector, represents about $24 \%$ of these total assets. Other sectors include: Securities, Insurance, Pensions and Government related.

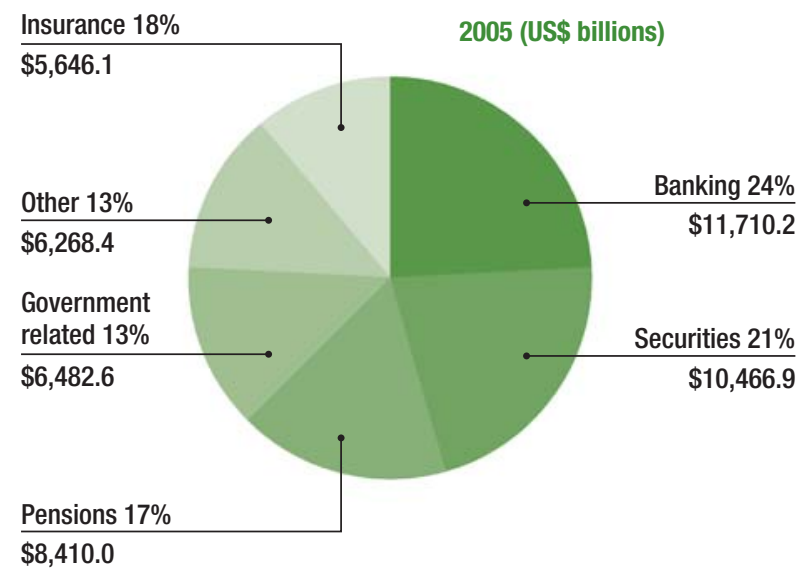

Source: US Board of Governors of the Federal Reserve (www.federalreserve.gov).
Conservation Association (IPIECA) ${ }^{\mathrm{d}}$ for the oil \& gas sector in 1970.The Energy and Biodiversity Initiative $(\mathrm{EBI})^{3}$, which was a joint initiative of a number of oil \& gas companies, i.e. BP, Shell, Statoil and ChevronTexaco, with a number of NGOs and research institutes, focused specifically on how biodiversity could be integrated into oil \& gas development. ${ }^{e}$ For agricultural commodities a roundtable has recently emerged for oil palm. ${ }^{\mathrm{f}}$

The financial sector has long remained absent on environmental issues. About 15 years ago the first European and US banks started to integrate environmental considerations in their credit lending activities. ${ }^{4}$ While a lot of banks are still struggling with how to integrate overall environmental risks into their lending activities, ${ }^{5}$ recent analysis indicates that more and more banks are integrating these considerations into their credit risk management procedures ${ }^{6,7}$ as well as into other types of financial services. ${ }^{8}$ As a result of increased concerns to address environmental issues in the financial sector, which is one of the largest sectors in the world (Box I), an increasing number of financial institutions (FIs) are also starting to voluntarily disclose information concerning the impact of their activities on the environment and the manner in which these impacts are managed within the firm. A report by KPMG ${ }^{9}$ indicated a huge increase in corporate sustainable reporting of 138\% between 2002 and 2005 in the G250" (Figure 1).

Figure 1. Number and percentages of companies in the G250 with CSR reports in 2002 and 2005

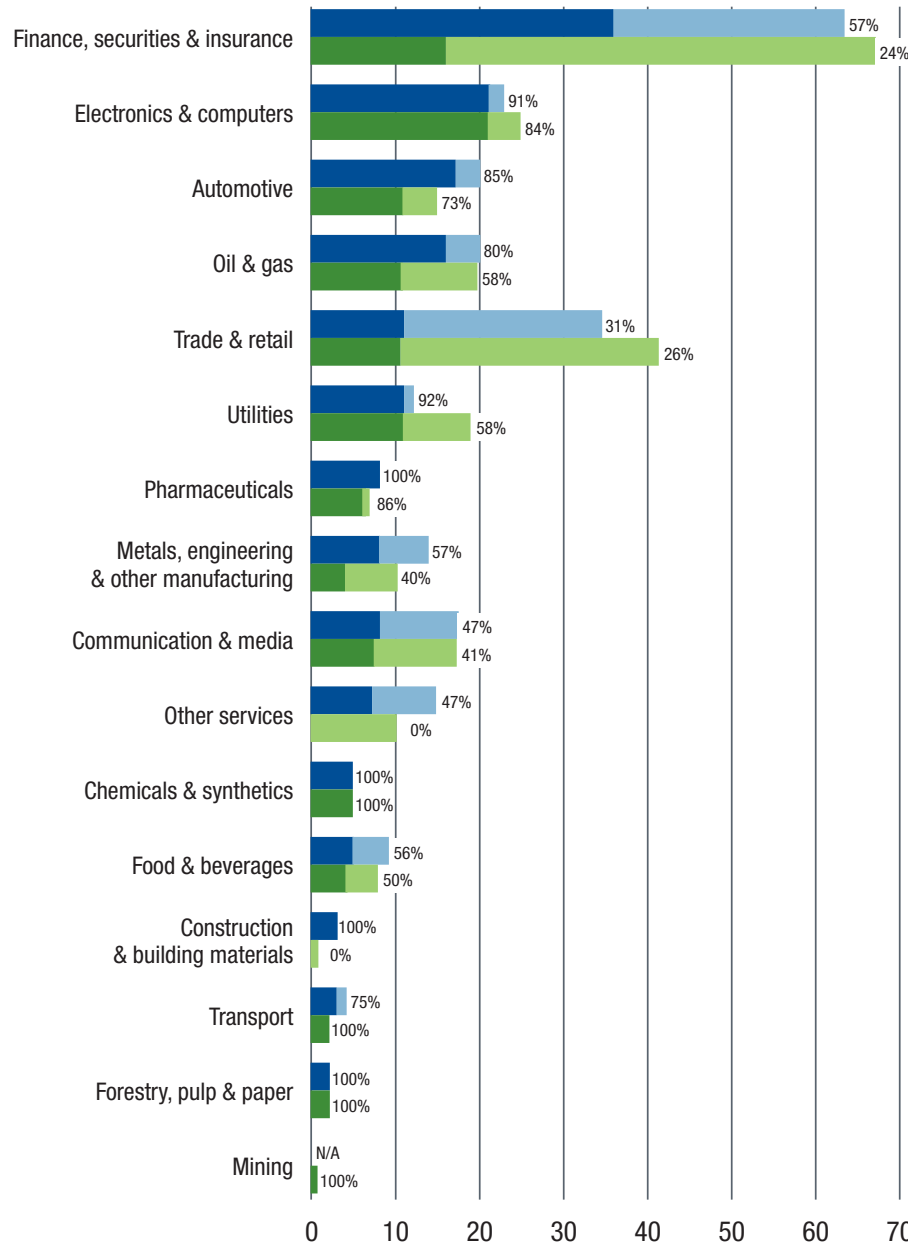


These days FIs such as the World Bank, ${ }^{\mathrm{h}}$ international commercial and investment banks and export credit agencies are beginning to develop environmental standards and conditions for lending to large infrastructure developments, such as oil \& gas projects. On biodiversity specifically, one of the leading companies is Insight Investment (the asset manager of the HBOS Group) which developed a biodiversity benchmark ${ }^{10}$ to assess biodiversity strategies, policies and management standards for a number of their clients in the mining \& metals, oil \& gas and utilities sectors. This benchmark has been endorsed by the Dutch and UK governments, Insight Investment, and recently also by Goldman Sachs. On a more global scale, the International Finance Corporation (IFC) in close collaboration with a number of large banks developed the Equator Principles ${ }^{11}$ for project finance. With respect to multilateral organizations, research institutes and NGOs, the most important organization is UNEP's Finance Initiative (UNEP FI). This organization encourages research on environmental, social and governance (ESG) issues and how these relate to financial institutions. In addition the organization provides a (convening) platform for its 160 members in the financial sector to learn more how extra-financial issues, such as ESG issues, touch upon their business and advocates adoption of policies and other means to integrate them in their operations.A couple of months UNEP FI officially launched its Biodiversity and Ecosystem Services work stream during its annual general meeting to guide their members on how to deal with emerging biodiversity issues. ${ }^{12}$ On a different note, there is Bank Track, a network of activist NGOs that aim to better integrate sustainable development issues, including biodiversity, in the financial sector. ${ }^{\mathrm{i}, 13}$

\subsection{Why should financial institutions account for biodiversity?}

So far, the focus of environmental risk assessments and internal screening by FIs has mainly focused on issues such as climate change, waste and energy use. Examples of available environmental instruments that guide financial institutions on these issues include for example: 1 ) the FORGE guidelines ${ }^{j}{ }^{j}$ ) the London Principles for financial institutions; ${ }^{14}$ 3) the OECD guidelines for Multinational Enterprises, ${ }^{15}$ and 4) the Dow Jones Sustainability Group Index (DJSGI). ${ }^{\mathrm{k}}$ Accounting for biodiversity has to a large extent remained nascent. At the same time, examples are building up that strengthen the point that biodiversity is increasingly becoming a business issue, either in the form of business risks or opportunities.

At the moment there are only a few tools available to guide FIs on how to integrate biodiversity into their risk management procedures and other business operations. Three noteworthy ones include:

- Biodiversity Benchmark. ${ }^{10}$ This tool has been developed by Fauna \& Flora International (FFI) and Insight Investment and focuses on assessing the biodiversity performance of UK extractive companies and utilities. Besides being endorsed by Insight Investment itself, Goldman Sachs uses it as well to guide their investment decision making.

- Equator Principles. ${ }^{11}$ This tool has been developed by the IFC in collaboration with ABN AMRO, Barclays, Mitsui and WestLB. It is intended to serve as a common baseline for the implementation by each endorsing FI (currently 41) of its own internal social and environmental policies, procedures and standards related to project financing activities specifically.

- Biodiversity Quickscan. ${ }^{16}$ This tool has been developed by CREM for the Dutch Association of Investors for Sustainable Development (VBDO). Although the tool has not been specifically developed for a type of private sector, the report outlines how it can be applied for the financial sector specifically.

A full overview of biodiversity tools is provided in Table 10.
These instruments are starting a process to encourage the financial sector to look at potential biodiversity risks and opportunities that may emerge from their indirect impacts on ecosystems (thus on biodiversity), as part of the wider spectrum of extra-financial issues. However, there is a need to build further on the business case for financial institutions and to effectively communicate it. This was highlighted by two UNEP FI meetings, ${ }^{17,18}$ where a number of FIs outlined key challenges/ barriers for financial institutions in the biodiversity/ecosystem services arena. These include:

1) Need to develop best practice case studies at the country and sector level to better inform financial institutions on risks and opportunities.

2) Difficulty in reconciling and communicating short-term private gains vs. long-term social (and private) impacts.

3) Need for disaggregating "ecosystem services" into more specific, "bite-sized" components or issues (e.g., fresh water, carbon, flood control); otherwise, the issue remains too big for an institution (e.g., bank) to tackle effectively.

4) Absence of relevant and effective regulatory frameworks and price signals.

5) Absence of consensus on ecosystem services valuation.

6) Need for developing capacity of consultants that work with banks on these issues.

In order for banks and other financial institutions to manage biodiversity risks that result from their investments, lending activities and insurance products, they need comparable, credible and reliable information on the size and nature of these impacts, how companies are dealing with them and how they affect their financial performance and/or shareholder value. ${ }^{19}$ This project aimed to contribute to the above mentioned challenges/barriers by focusing on 1) the biodiversity business case for FIs in terms of risks and opportunities; 2) how biodiversity-related business risks (BBRs) differ between financial institutions; and 3) how financial institutions can integrate biodiversity into their operations. By accounting for BBRs FIs are:

1) Better capable to understand their relation to biodiversity and how that affects their (financial) bottom line. While Goldman Sachs has stated that one-off (negative) environmental events have limited influence on a company's share price, ${ }^{20}$ banks and other FIs need to realize that when providing loans to or investments in high biodiversity impact sectors, such as the mining sector or oil \& gas sector, biodiversity issues are becoming more important from a risk perspective. This sector will be increasingly looking for remote offshore oil and gas fields, which are more complex for exploration and production. This will likely induce higher BBRs. FIs that understand the relation between companies and ecosystems are better positioned to identify how this relates to their own financial bottom-line.

2) Increase capacity to proactively respond to biodiversity business risks (BBRs) in the short and long term. By understanding how biodiversity and related ecosystem service are touching upon the financial bottom-line FIs can build capacity to identify and mitigate at an early stage what types of BBRs they are exposed to in the short term, such as reputational risks, and in the long term, such as reduced investment returns or increased risk for default.

3) Identify and capture biodiversity business opportunities (BBOs). In addition to hedging risks, FIs that have built capacity are better positioned to identify biodiversity business opportunities (BBOs), such as growing markets for biocarbon, certified sustainably produced commodities and advisory services to clients that need to be guided on biodiversity-sensitive projects or transactions.

h The World Bank Group has commissioned an independent review, the Extractive Industries Review (EIR), to discuss its future role in the oil, gas and mining sectors with concerned stakeholders and produce a set of recommendations that will guide their involvement in these sectors.

i See www.banktrack.org Association. http://www. ipieca.org i See http://www.abi.org.uk/forge/ForgeText.htm

${ }^{\mathrm{k}}$ See www.sustainability-index.com 
In terms of outreach, it is anticipated to feed the outcomes of this report into existing initiatives such as the Business and 2010 Biodiversity Challenge, ${ }^{21}$ UNEP FI's Biodiversity and Ecosystem Service work stream, and IUCN's Business and Biodiversity Programme.

\subsection{Project objectives}

This project focused on the following four objectives:

1. Identify the business case for biodiversity for financial institutions from a risk perspective

2. Assess how commercial banks, asset managers and insurance firms can be exposed to biodiversity risks;

3. Identify the tools that are available for financial institutions at present that enable them to integrate biodiversity into their risk management procedures;

4. Identify biodiversity business opportunities for financial institutions.

\subsection{Methodology}

The research for this project was conducted between September 2006 and January 2007. In general, information for this project was gathered through literature reviews and interviews with representatives from financial institutions, mainly in the banking sector, and other stakeholders (i.e. NGOs, multilateral institutions, consultancies and research institutes).

\subsection{Audience}

This report is primarily written for financial institutions to enable them to better understand the business risks and opportunities related to biodiversity. The information that is provided throughout the report is useful for a range of FIs, including retail and commercial banks, institutional and private investors, asset managers, and (re)insurance companies.

In addition, this report is also written for other stakeholders, most notably policy makers, NGOs, and multilateral organizations, that are interested in understanding the linkages between the financial world and ecosystems and what their role can be in increasing awareness of the business case for biodiversity and mainstreaming the issue throughout capital markets.

\subsection{Key definitions}

Biodiversity. The most widely used definition for biodiversity is the one used by the Convention on Biological Diversity (CBD), which defines it as "the variability among living organisms from all sources including, inter alia, terrestrial, marine and other aquatic ecosystems and the ecological complexes of which they are part. This includes the diversity within species, between species, and of ecosystems." 22 This report follows this definition and emphasizes that it forms the foundation of the vast array of ecosystem services that critically contribute to human wellbeing.

The financial sector. This is one of the largest (Box I) and most complex sectors in the world. It comprises institutions and companies. The sector includes banks, investors, asset managers, insurance and reinsurance, credit rating agencies and importexport agencies.

\subsection{Structure of the report}

Following the introduction, chapter 2 briefly explains the context of biodiversity loss: What are the direct and indirect drivers, what are future trends and how does this relate to the private sector. Since biodiversity business risks are likely more significant from a financial perspective, the larger part of this report focuses on the risk side. Chapter 3 starts by explaining the relationship between the financial sector and biodiversity. The core of this chapter focuses what types of BBRs financial institutions can become exposed to, and what evidence is available to strengthen (or weaken) the business case. Chapter 4 argues that biodiversity risks (and opportunities) may differ between different types of financial institutions. Through it is recognized that there are other (important) segments in the financial sector, the chapter focuses specifically on retail and commercial banks, asset managers/investors, and the insurance sector. Chapter 5 provides a general procedure for FIs to integrate biodiversity into their risk management process. Where the last three chapters focus on the business case from a risk perspective, chapter 6 outlines a number of biodiversity business opportunities that FIs can capture, including potential market sizes. Chapter 7 draws conclusions from the findings of the research project. Chapter 8 provides recommendations on how to work towards a more widespread integration of biodiversity throughout the risk management practices and other business operations within financial institutions. 


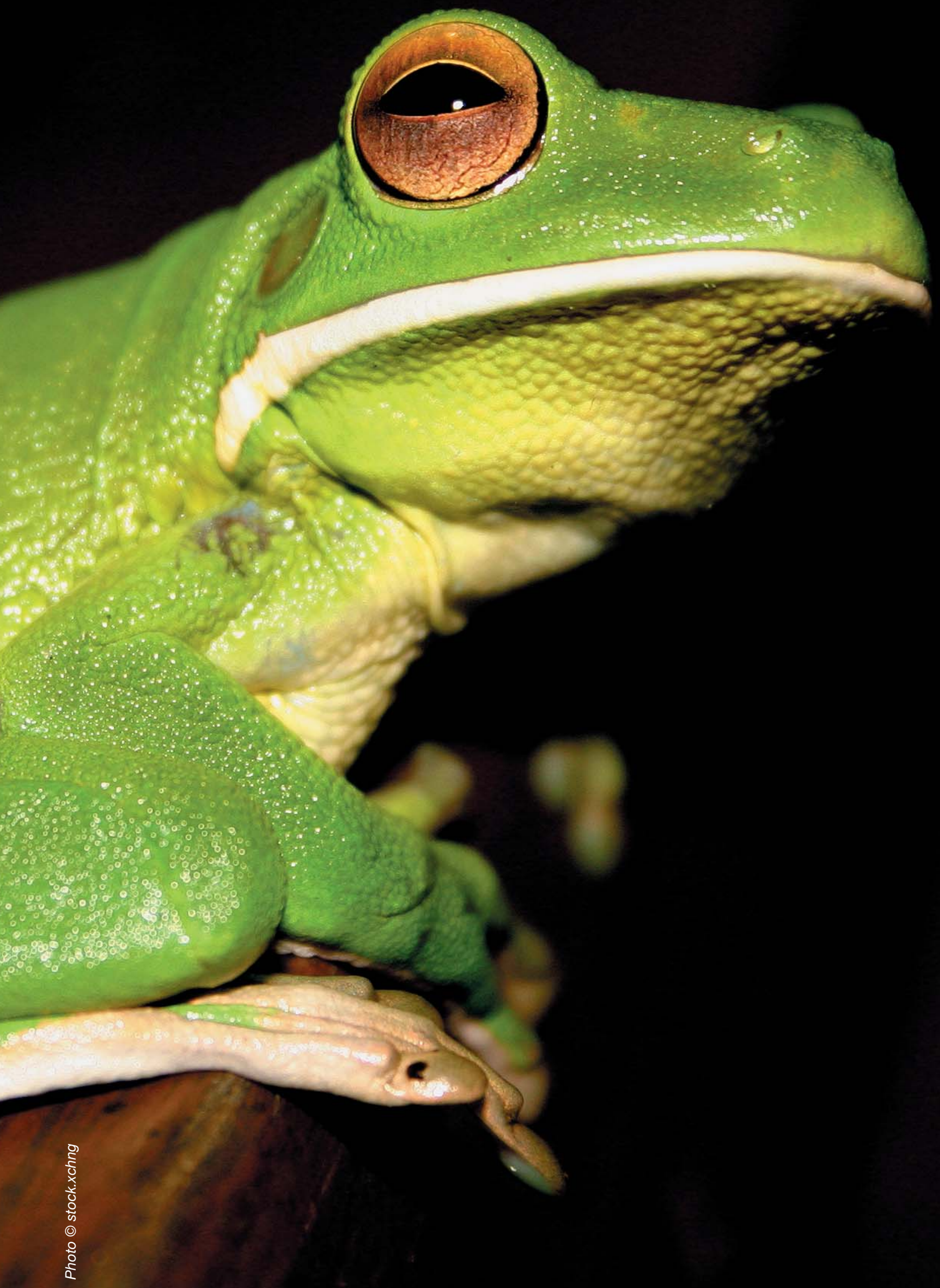




\section{Biodiversity loss: a growing relevance for the private sector}

The materiality of social, environmental and governance issues in investment decision-making has been highlighted by various reports. ${ }^{23,24}$ Climate change is a good example. This phenomenon rose up the international agenda when a growing body of scientific evidence showed that human-induced greenhouse-gas emissions had a direct impact on the atmosphere and would cause shifts in climates both globally and regionally. Although this phenomenon was hardly recognized by anybody 20 years ago, today as a result of international treaties, national legislation and the creation of carbon markets, climate change has become a real business issue for the private sector.The recent emergence of the European Emissions Trading Scheme (ETS) also means that the financial sector is becoming more and more active in this new market, as brokers, traders and types of other intermediary services. At the moment there is about $£ 5.8$ billion under management in 51 carbon funds. ${ }^{1}$

\section{|Ш||||||||||||||||||||||||||||||||||||||||||||||||||||||||||||||||||||||||||||||||||||||||||||||||||||||||||||||||||||||||||||||||||||||||||||||||||||||||||||||||||||||||||||Ш||| \\ IN A REPORT BY F\&C INVESTMENTS (2004) \\ TOM Massey, FROM RWE POWER, STATES THAT \\ "FifTEen years ago, COMPANIES WERE SAYING THAT Climate CHANGE WAS NOT RELEVANT TO BUSINESS. YOU COULD NOT MEASURE IT, COMPANIES HAD NO INDIVIDUAL RESPONSIBILITY FOR IT, AND THERE WERE NO GLOBAL REGULATIONS TO CONTROL \\ IT. MANY COMPANIES ARGUED IT WAS NOT HAPPENING AT all. SCientific EVIDENCE and government aCtion haVe FUNDAMENTALLY CHANGED THIS SCENARIO. I BELIEVE THAT THE ISSUE OF BIODIVERSITY COULD WELL TAKE THE SAME PATH.”}

Source: F\&C Investments, 2004. Is biodiversity a material risk for companies? An assessment of the exposure of FTSE sectors to biodiversity risk. London, United Kingdom.

The question of course is whether biodiversity will follow the same path as climate change.This depends on a number of factors, including whether a clear business case for FIs can be developed and effectively communicated, the ability to create and sustain biodiversity markets, and how trends in degradation and loss of biodiversity will emerge in the coming years and decades. The most authoritative and recent publication that contributed to answering this question is the Millennium Ecosystem Assessment (MA). ${ }^{25}$ The MA assessed the consequences of ecosystem change for human well-being and established the scientific basis for actions needed to enhance the conservation and sustainable use of ecosystems and their contributions to human well-being. It involved the work of more than 1360 experts worldwide.

This chapter therefore briefly highlights the direct and indirect drivers of biodiversity loss, current trends, and based on these findings predict a plausible range of how biodiversity loss will further develop in the coming decades and how this will affect business in general.

\subsection{Direct drivers of biodiversity loss}

The following direct drivers have been identified:

1. Habitat change. This has been the most important direct driver for changes in terrestrial ecosystems. Cultivated systems, as a result of agricultural activities, cover at present $24 \%$ of the Earth's surface.Agriculture causes a net loss in global forest cover of around 13 million hectares per year (Figure 2), of which Brazil accounts for $24 \% .{ }^{26}$ With respect to primary forests there is an annual reduction of $0.52 \%$. Especially in Latin America, some $70 \%$ of previously forested land in the Amazon is used as pasture, and feed crops cover a large part of the reminder. ${ }^{27}$
Figure 2. Annual net change in forest area by region 1990-2005 (million ha per year)

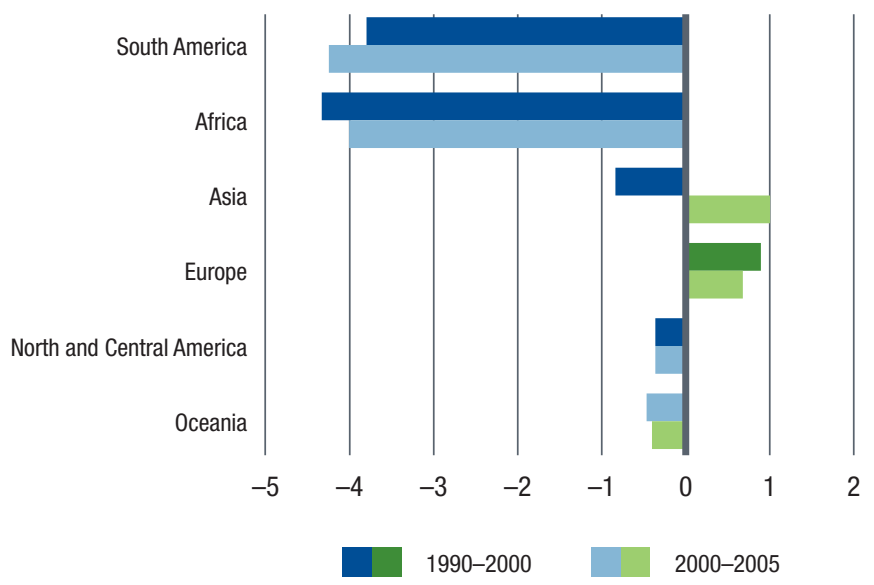

Source: FAO, 2005. ${ }^{26}$

2. Climate change. This driver has emerged over the last decades and is causing a rapid increase in impact across all ecosystems in the world. The new $4^{\text {th }}$ assessment by the Intergovernmental Panel on Climate Change (IPCC) ${ }^{28}$, released on 6 April 2007, indicates that evidence is growing that climate change has very significant impacts on natural and human environments and that the net effects tend to be negative for industry and society. A study by Thomas et al. (2004) 29 predicts that between $15-37 \%$ of species (which can be a proxy for biodiversity) in their sample of regions and taxa will be 'committed to extinction' by 2050 as a result of a mid-range climate-warming scenario. The study covered $20 \%$ of the Earth's terrestrial surface and used geographical range sizes of species to measure extinction risks. Since the Intergovernmental Panel on Climate Change predicts an increase in temperature of $2.0-6.4^{\circ}$ Celsius above preindustrial level in 2100 , climate change will probably become the key driver in global biodiversity loss by the end of the century.

3. Invasive species. The introduction of non-native species, especially in freshwater ecosystems and on islands, is among the most important drivers for species extinction (other then physical changes, modification of water regimes and pollution).

4. Overexploitation. Especially for marine ecosystems, the most important driver for loss of biodiversity has been over-fishing. A shocking example is the major over-fishing of cod off Newfoundland (Figure 3).

Figure 3. Cod landings in tons off the coast of Newfoundland

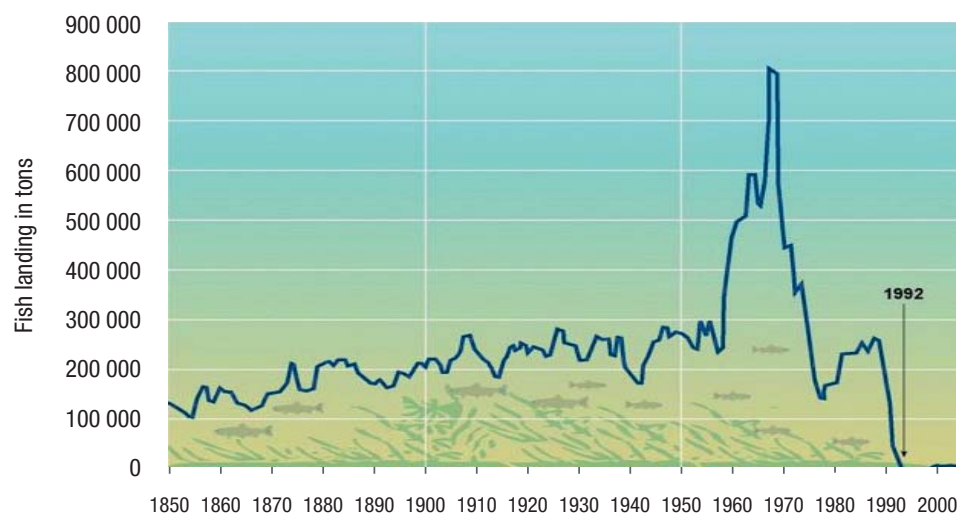

Source: Millennium Ecosystem Assessment. ${ }^{2}$ 
Overexploitation of bush meat (wild meat taken from the forests by local people) share similar concerns to those of fisheries, where sustainable levels of exploitation remain poorly understood. Reduction of quantities (and qualities) of specific commodities (types of meat and fish) can cause scrutiny in the supply chain and lead to extra costs for companies in the chain. This is turn can influence FIs when companies are unable to pay-back a loan (default), lower returns on investment (ROI) or reputational risk for financing companies with a bad reputation.

5. Pollution. This has been an important driver for change in terrestrial, freshwater and coastal ecosystems and mainly concerns synthetic nitrogen and phosphorus used as fertilizers. Especially the last two decades saw a sharp increase in the use of nitrogen and phosphorus and future scenarios predict a further increase, especially in developing countries.

\subsection{Indirect drivers of biodiversity loss}

The MA indicates that while biodiversity change is clearly a consequence of the above-mentioned direct drivers, these direct drivers are being fed by indirect drivers of biodiversity change. They are the root causes of changes in ecosystems. The following indirect drivers have been identified:

1. Changes in economic activity. Global economic output has increased almost sevenfold between 1950 and 2000 and is projected to grow a further three- to sixfold by 2050 .

2. Demographic changes. Global population doubled in the past 40 years, reaching 6 billion in 2000 , and is projected to grow to 8.1-9.6 billion by 2050. Furthermore, a major urbanization wave is occurring especially in developing countries (which will generally lead to an increase in demand for food and energy, thereby increasing pressures on ecosystems worldwide).

3. Socio-political factors. The past 50 years have witnessed significant changes in socio-political drivers, including a decline in centralized authoritarian governments and a rise in elected democracies, which allows for new forms of management, in particular adaptive management, of environmental resources. Examples in recent years include Ukraine and Kyrgyzstan.

4. Cultural and religious factors. This can influence people's perceptions of nature and consumer preferences.

5. Scientific and technological change. Looking at it from a biodiversity perspective, this can be regarded as a double-edged sword. On the one hand it can lead to increased efficiency in resource use and on the other hand it can provide the means to increase the exploitation of resources.

\subsection{Trends and estimates for future biodiversity loss}

There is a growing body of literature that provides trends on the decrease in populations and/or extinction of certain specific taxa of species, such as mammals, amphibians, birds, etc. A yearly global study, undertaken by WWF since 1998, is called the Living Planet Index. ${ }^{\mathrm{m}}$ This index is a measure of the state of the world's biodiversity based on trends from 1970 to 2003 in over 3600 populations of more than 1300 vertebrate species from around the world. It is calculated as the average of three separate indices that measure trends in populations of 695 terrestrial species, 274 marine species, and 344 freshwater species. The overall index in the 2006 report shows a $30 \%$ drop, compared to the baseline year $1970 .{ }^{30}$ Further evidence on biodiversity decline can be provided from IUCN's Red List Programme. ${ }^{\mathrm{n}}$ Its indices illustrate the relative rate at which a particular set of species changes in overall threat status (i.e. projected relative extinction-risk), based on population and range size and trends as quantified by Red List categories. The indices provide evidence of the decline in (critically) threatened and/or vulnerable species, which have declined on average about $8 \%$ in 16 years for threatened mammal, marine and freshwater bird species from its baseline year $1988^{31}$ (Figure 4).

With respect to trends of future losses, the direct drivers will likely increase their impact on biodiversity in the coming decades according to the Ecosystem Millennium Assessment (MA).The four scenarios that the MA used indicate a loss in habitat, calculated with the IMAGE model, between 13-20\% using 1970 as a baseline. Based on well-established species-area curves for vascular plant species the loss in habitat will lead to a loss in biodiversity between 10-15\%. This rate of extinction will further increase through overexploitation, invasive species and climate change. Based on data that the MA team had available they predicted a huge increase in loss of species of more than 100 times the current extinction rates (Figure 5).

\footnotetext{
${ }^{\mathrm{m}}$ http://www.panda.org/news_facts/publications/living_planet_ report/index.cfm
}

${ }^{n}$ http://www.iucnredlist.org/
4. a.

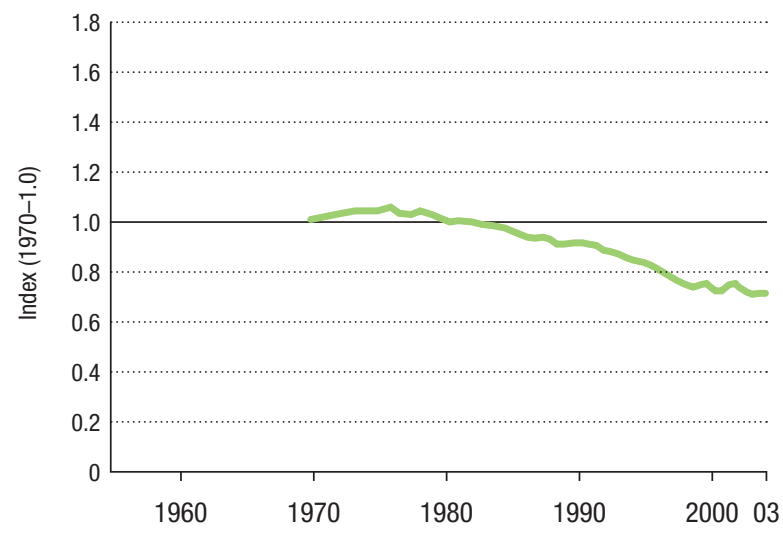

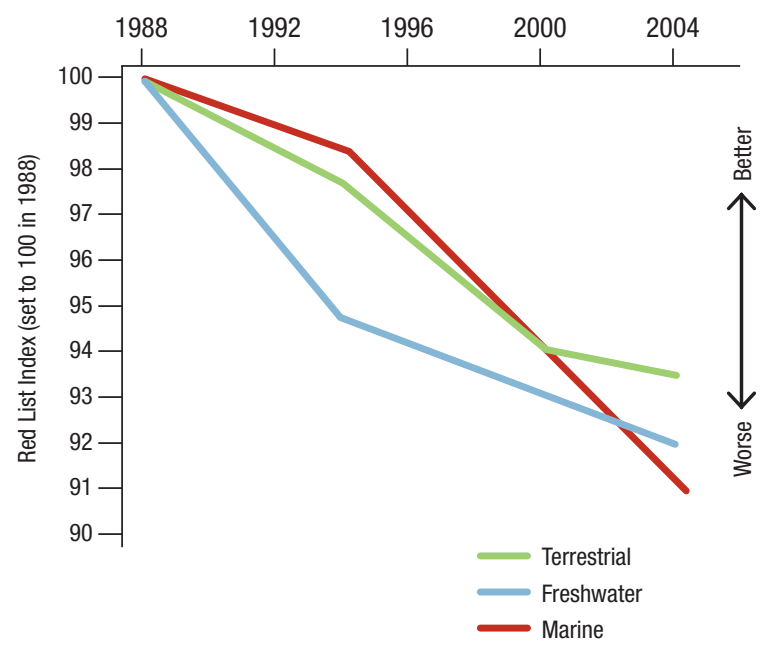


Other than opportunities, the risks and challenges that the private sector faces are arguably more substantial. Consider the case of Associated British Ports. This company saw a drop in its stock of almost $10 \%$ in a single day after the announcement by the Ministry of Transport to block a harbour development plan for Southampton by this company. One of the reasons was that the company had insufficiently taken account of the environmental and biodiversity risks (see Box VIII). The MA recognized the following challenges and risks for the private sector in general: ${ }^{2}$

- Increased regulatory constraints from governments;

- Risk to reputation and brand image;

- Substantial increase in costs of important inputs (e.g., water);

- Increased vulnerability of assets to floods or other natural disasters.

The example of Associated British Ports is one in a growing body of evidence that indicates that global decline in biological resources is slowly setting in motion a number of powerful drivers, such as concerns by governments and policy makers, shifting consumer preferences, scrutiny from pressure groups and investors who increasingly demand good company-husbandry. These drivers tend to interact and amplify each other, which is culminating in a growing relevance of biodiversity to the private sector (see Figure 6).

The question of course is to what extent do the above-mentioned risks apply to the financial sector? Is there a business case for biodiversity from a financial sector's perspective? This will be the scope of the following chapter.

Figure 6. Linking biodiversity loss to business relevance

\subsection{Translating biodiversity loss into business risks and opportunities}

From a business perspective it is important to understand how these trends and expectations translate into business risks and opportunities for the private sector. The $\mathrm{MA}^{2}$ recognized the following opportunities:

- New markets and product opportunities to address ecosystem service scarcity;

- Enhanced corporate image and reputations when reacting proactively;

- Cost and operational advantages from early recognition and action.

Compared to carbon, it can generally be said that biodiversity as a commodity is much harder to quantify, package and trade. However, in order to increase leverage for biodiversity conservation a noticeable development has emerged that attempts to internalize the value of biodiversity and other ecosystem services ${ }^{\circ}$ into tradable products. This is called "payments for environmental services" or "payments for ecosystem services", which can be seen as a means of broadening the types of financial mechanisms from purely public donations, governments' Overseas Development Assistance (ODA) and private donations, to market mechanisms. Two sizeable markets have already been established in the United States: wetland mitigation banking (offsetting damage done to wetlands) and conservation banking (offsetting of land containing endangered species). These markets have been similarly established as those for carbon, namely by placing a gap or floor.At present, these markets represent market volumes of US $\$ 290$ (wetland mitigation banking) and US $\$ 40$ million (conservation banking). ${ }^{\text {p Valuable }}$ and rewarding attempts have been made as well in Latin America (particularly Costa Rica), Europe,Asia and to a lesser extent in Africa ${ }^{32}$ although these often consist of one-off deals rather then fully grown markets.

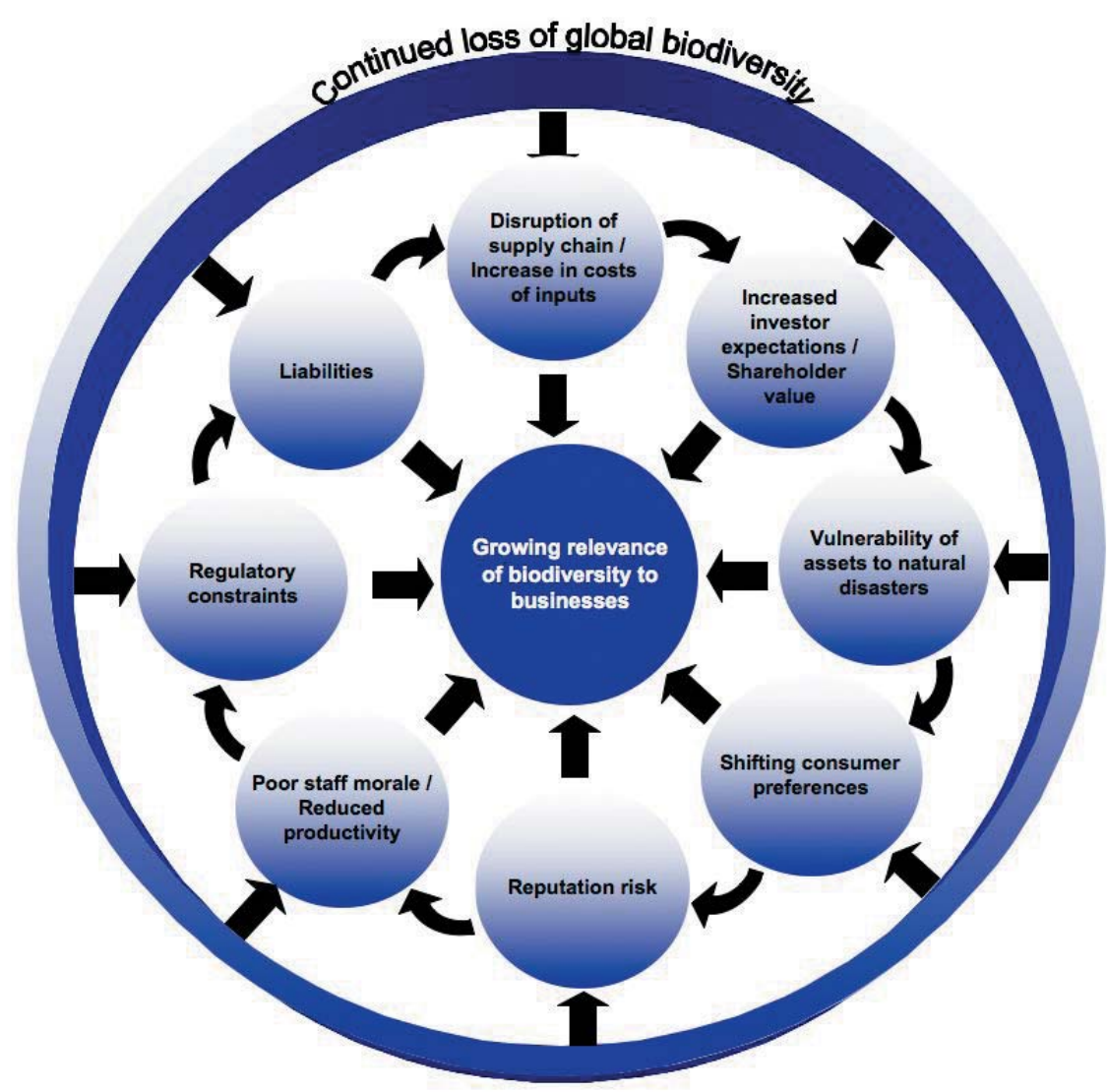

${ }^{0}$ These include: 1) Provisioning services (food, fiber, genetic resources); 2) Regulation services (e.g., climate regulation); 3) Cultural services (e.g., spiritual and religious values and recreation and tourism).

p See www.ecosystemmarketplace.com. The market volume for wetland mitigation banking has been measured between 1 January 2000 and 30 April 2005. The market volume for conservation banking has been measured between 1 January 1992 and 25 May 2005. 


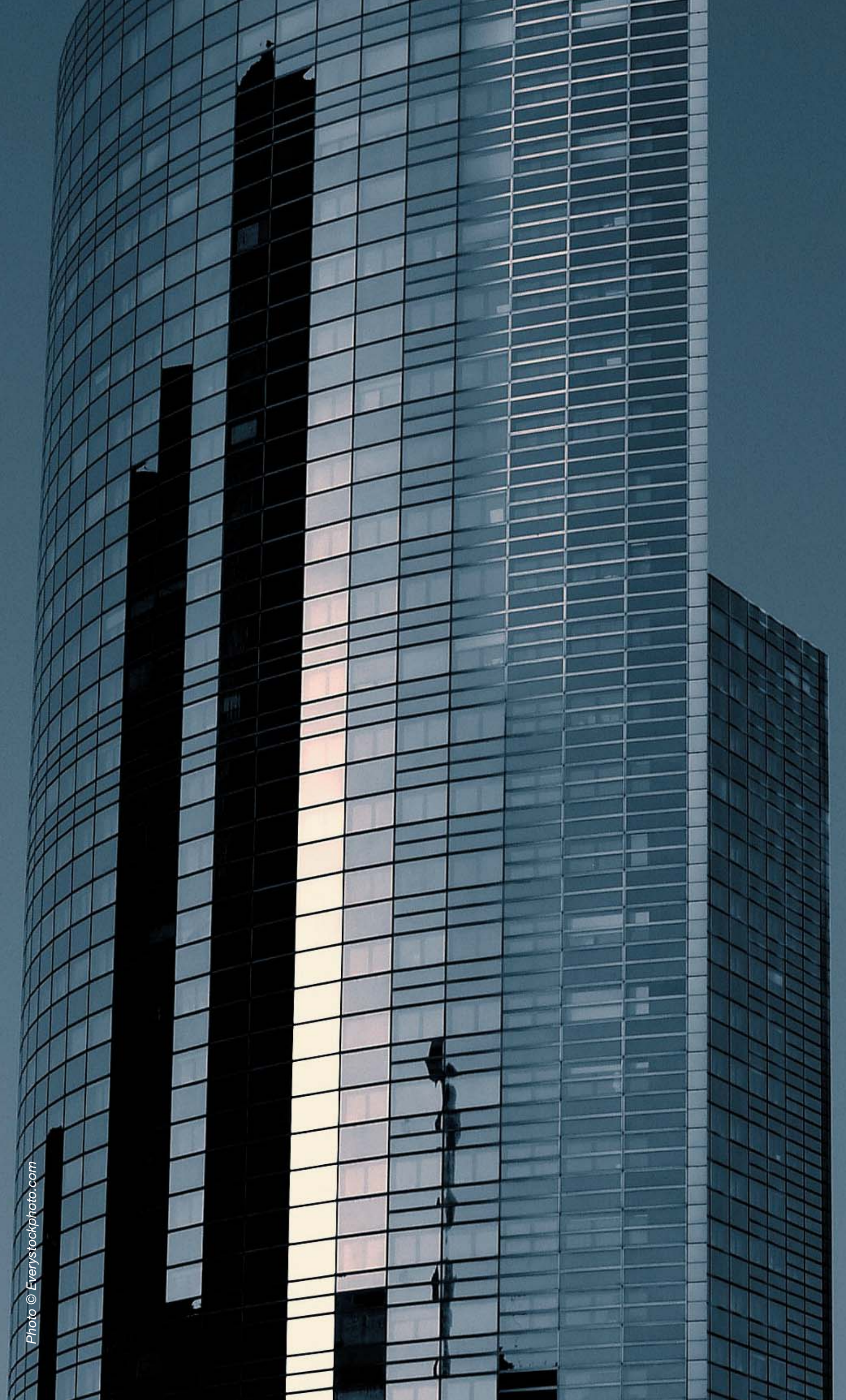




\section{The business case for biodiversity for financial institutions from a risk perspective}

While the rationale to account for biodiversity in a company's business operations has only been made clear for extractive industries (although it remains unquantified at present) the business case for biodiversity from a financial sector perspective is underdeveloped ${ }^{17}$.This chapter aims to contribute to a better understanding of it from a risk perspective ${ }^{\mathrm{q}}$. Section 3.1 draws attention to the relationship between financial institutions and ecosystems and how impacts relate to direct and indirect risks for financial institutions. Section 3.2 provides results of an interview survey that assess the business case for biodiversity from a financial sector's perspective. Section 3.3 assesses what evidence is available to back up the business case for biodiversity. Section 3.4 outlines how drivers for BBRs add up

\subsection{The relationship between ecosystems and the financial sector}

Porter and Kramer (2006) ${ }^{33}$ argue that sustainability issues are so disconnected from a company's business strategy and operations that they offer insufficient guidance for companies to start incorporating them into a company's business operations. Other than simply stating that there are moral and sustainability arguments for companies to start addressing for environmental and social issues, it is important to understand the interconnectivity or relationship between companies and society. This can be done by analyzing the corporate value chain, which are all the activities a company engages in while doing business, and by analyzing how society impacts on a company, in terms of the specialized inputs available to a company (e.g., natural resources) and the availability of highly qualified and enthusiastic employees among others.

Applying their concept to financial institutions and ecosystems, the question can be posed: How impacts on ecosystems relate to biodiversity business risks (BBRs) that financial institutions are exposed to? First, it should be understood that all businesses have an impact on biodiversity through their operations. However, there is a great difference between sectors in terms of their impact on biodiversity. Some sectors have a high impact on biodiversity, such as the oil \& gas sector or the mining \& metals sector, while other sectors have substantially less impact, such as the telecommunications sector. FIs have a twofold impact on biodiversity as part of their operations

- Direct impacts: These constitute primarily use of land (i.e. buildings), energy consumption, paper use and waste.

- Indirect impacts: By providing financial services (loans, bonds, equity, etc) to companies that have a direct or even an indirect (high) impact on biodiversity.

While the direct impacts of FIs are generally limited, the indirect impacts can be very considerable, depending on the type of financial institution, service and portfolios. A report by F\&C Investments (2004) ${ }^{34}$ revealed that $80 \%$ of the respondents during a workshop believed that banks, insurance and investment companies have a medium to high impact on biodiversity. These assumptions were based on 1) the proportion of companies likely exposed to biodiversity risk; and 2) the significance of risks faced by individual companies. For purposes of clarification, this project focuses primarily on the indirect impacts that FIs have on biodiversity. Although the direct impacts cannot always be neglected these have been put outside the scope of this project.

While business may have an impact on ecosystems, the same holds true vice versa. This impact can be positive, in the form of opportunities. For example when a company adequately recognizes and manages its impact on biodiversity it might circumvent future regulation, build capacity with key stakeholders and safeguard its reputation. On the other hand biodiversity can turn into a risk when biodiversity issues are at stake, but are not recognized and managed by a company. In this case, it might turn into a liability, damage a company's reputation or lead to regulatory constraints. Financial institutions can be indirectly affected by these ecosystem constraints, particularly from two types of client companies:

- Clients having (high) impacts on ecosystems. These include companies with direct footprints on ecosystems, such as the oil $\&$ gas sector and utilities, or sectors that have a significant impact through their supply chains, such as the food retail sector.

- Clients depending on ecosystem goods and services. These include for example the tourism sector, agriculture, forestry or the fisheries sector.

FIs that provide financial services to these types of sectors can be exposed to BBRs, both directly and indirectly (Figure 7). Directly, FIs can be exposed to liability risks or reputational risks when a project that comes under heavy biodiversity-related scrutiny attracts major NGO attention. Indirectly, FIs can be exposed to biodiversity risks for loans to and investment portfolios in the above-mentioned types of companies. As biodiversity will likely increase in relevance for these types of companies in the coming years, some of them may increasingly come under biodiversityrelated scrutiny. FIs that are not positioned to identify which companies are most at risk can be exposed to lower ROIs, increased risk for default or an increase in insurance claims.

q Chapter 6 subsequently focuses on biodiversity business opportunities.

Figure 7. The dual link between biodiversity and the financial sector: The corporate value chain (impacts on ecosystems) and influences on competitiveness (risks and opportunities)

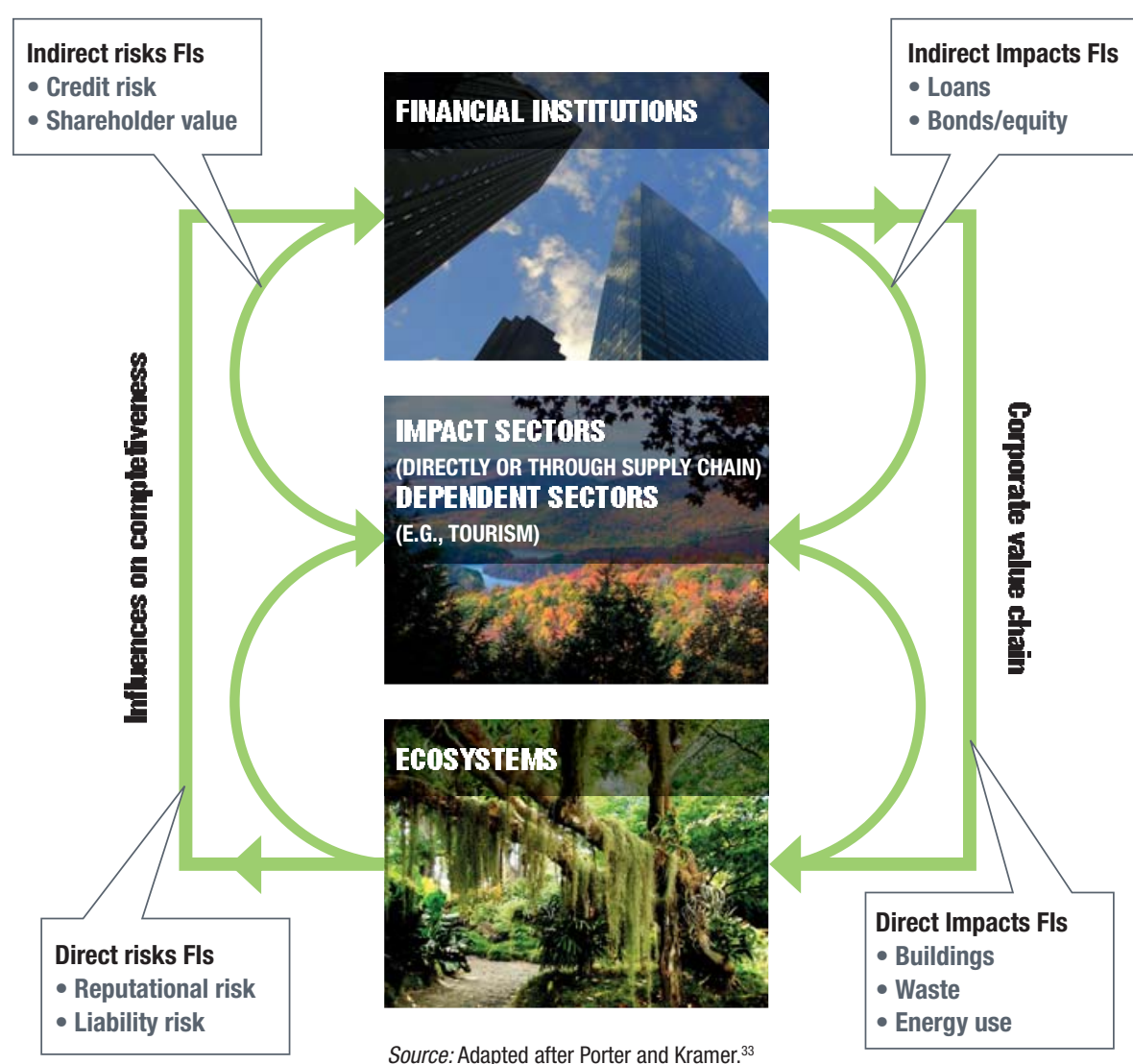




\subsection{Types of biodiversity business risks that financial institutions can be exposed to}

Although many businesses have been addressing environmental issues for decades, until recently, FIs had been indifferent to environmental issues ${ }^{19,35,36}$ because:

1. General confusion exists about the importance of environmental issues, together with uncertainty how their effects should be measured;

2. Difficulty in reconciling and communicating short-term private gains vs. long-term social (and private) impacts;

3. Prices of natural resources do not reflect possible future shortages or their unsustainable use;

4. The financial sector did not see environmental issues as a separate moral issue, but just as another pressure.

However, these attitudes are changing. ${ }^{19,37}$ The financial sector increasingly understands that environmental issues have an impact on business and therefore need to be properly addressed. Weber et al. (in press) ${ }^{4}$ outlined a number of environmental risks that banks for example face in their lending activities that may impact on credit risk: ${ }^{4,38,39}$

- Sites used as collateral that are contaminated. Contamination of a site affects the value of the collateral in a significant way, because remediation is costly.

- Regulatory driven investments. When a bank is obliged to invest in environmental-related activities (e.g., environmental technological development) and it does not have the capacity to assess this, it might run into costs.

- Market changes. Attitudes by consumers and investors can change.

- Reputation risk. When banks engage with companies that have bad environmental records, it can harm the reputation of the bank.

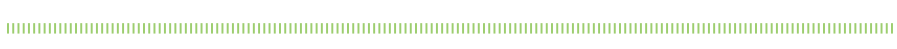

"ISSUES SUCH AS BIODIVERSITY ARE RELATIVELY NEW FOR THE FINANCIAL SECTOR. IT IS IN THEIR SELF-INTEREST TO SHAPE NEW POLICIES."

James GRIfFiths, WBCSD

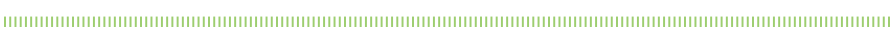

While concerns have so far mainly focused on a company's energy efficiency, the corporate $\mathrm{CO}_{2}$ footprint and use of waste, biodiversity is an issue that is just starting to be addressed by financial institutions. The literature that is available outlines drivers for the private sector in general to engage actively in reducing the impact on ecosystems by incorporating biodiversity into its business operations: $:^{2,5,10,19,40}$

- Disruption of the supply chain/increase in costs of inputs;

- Increased vulnerability of assets to floods and other natural disasters;

- Conflict and corruption in areas scarce in ecosystem services;

- Lower ratings in financial markets/shareholder value;

- Poor staff morale and reduced productivity;

- Reputational risk;

- Regulatory constraints/legal license to operate;

- Liabilities.
Since the business case for biodiversity has only to a minor extent been addressed for the financial sector specifically, an interview survey was conducted with 12 financial institutions, especially banks, and 13 NGOs and multilateral institutions. Due to the global significance of this issue a number of NGOs, multilateral organizations and other private sector companies, which were familiar with the issue, were consulted as well (see Annex I for an overview of the respondents, and Annex III for the questionnaire). The question that was posed to all respondents concerned: $D o$ you believe there is a business case for biodiversity from a financial sector's perspective? ${ }^{\text {r }}$ The results of this survey are shown in Figure 8. The percentages in Figure 8 indicate how many of the respondents in the group "financial sector" or "other stakeholders" found a certain motivation to be a convincing biodiversity business case for FIs.

As it turns out, the available body of literature, but even more the interview results clearly reveal that reputational risk is the most prominent type of biodiversity risk for the financial sector. Nineteen out of $26^{\mathrm{s}}$ (>70\%) of the respondents believe there is a business case for biodiversity because of reputational damage the financial sector can face. In addition respondents from the financial sector indicated liability risk, social license to operate, credit risk and reduced shareholder value as additional types of risk, although they were regarded as less important (at present). Regulatory constraints from policy makers and access to capital (for emerging market FIs) were only stated by 'other stakeholders'. Other types of risks, such as poor staff morale, were hardly regarded as being a risk issue for the financial sector.

Figure 8. The business case for biodiversity from a financial institution's perspective - information gathered during interview surveys ${ }^{t}$

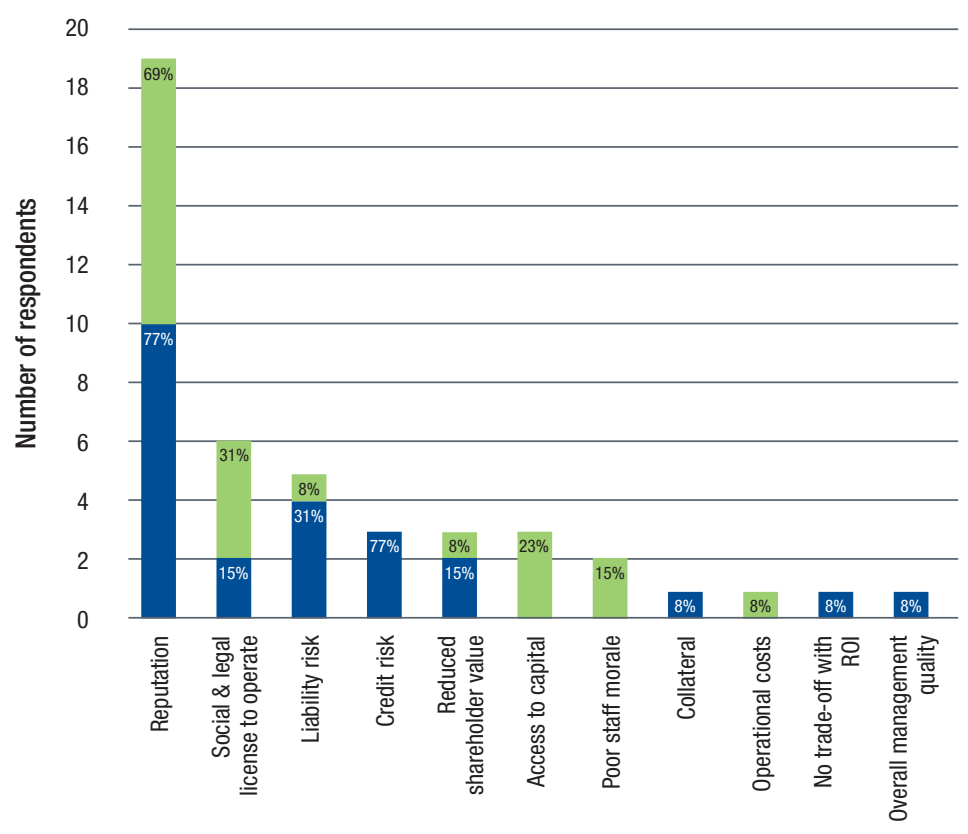

Other stakeholders -13 organizations and companies

Financial sector -13 companies (of which 12 by interview)

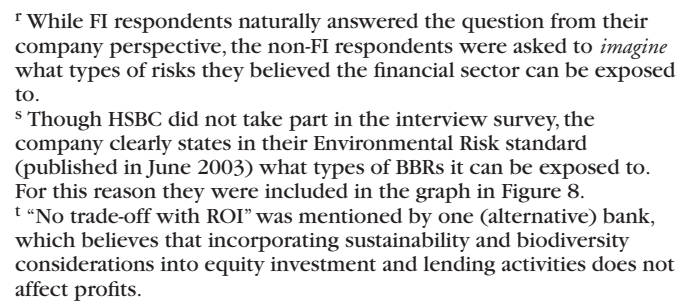

${ }^{\mathrm{r}}$ While FI respondents naturally answered the question from thei company perspective, the non-FI respondents were asked to imagine what types of risks they believed the financial sector can be exposed to.

${ }^{s}$ Though HSBC did not take part in the interview survey, the company clearly states in their Environmental Risk standard (published in June 2003) what types of BBRs it can be exposed to. For this reason they were included in the graph in Figure 8. t "No trade-off with ROI" was mentioned by one (alternative) bank, which believes that incorporating sustainability and biodiversity considerations into equity investment and lending activities does not affect profits. 


\subsection{Evidence of biodiversity business risks for financial institutions}

In order to understand if there is indeed a business case to address biodiversity from a financial sector's point of view, this section provides an overview of cases that sheds some light on how tangible the business case for FIs is.

Due to the indirect relation between the financial sector and biodiversity and due to data limitations it is difficult at present to measure the financial implications of BBRs in terms of market capitalization or asset values (standard financial metrics). "Evidence" has therefore been sought anecdotally, in terms of examples, case studies and trends. Some of the cases are directly targeted at FIs (i.e. direct BBRs), while in other cases the business case is expressed indirectly (i.e. indirect BBRs). This can for example be by providing evidence how insufficient accounting for biodiversity risks can lead to reduced shareholder value for construction companies or oil \& gas companies, which can directly impact on both private and institutional investors.

The information in this section has been gathered through literature reviews and consultations with experts.

\subsubsection{Liability risks}

The last years have seen a growing number of initiatives (especially in developed countries) to hold companies directly responsible for environmental damage. Investors and banks can be impacted twofold. Indirectly, they are impacted when a project they have invested in or provided a loan to is subject to unforeseen costs, such as liabilities resulting from failures to recognize and manage the impacts on the environment and biodiversity. This may eventually result in lower returns on investment or increased risk for default. Second, they are directly impacted when they are being held liable themselves for environmental damage from companies they have invested in or provided loans to. Other than for investors, liabilities are foremost connected to the insurance and re(insurance) business, as they have a sharp eye fixed on newly developing liability legislation. This is especially so in Europe where from April 2007 operators will be held legally liable for damage to the environment (Directive 2004/35/EC). ${ }^{41}$ Since the Fleet Factors case (see Box II) this is already the case for contaminated sites in the US for both operators and lenders of the capital (e.g., banks).

The directives and treaties that are listed in Table 1 provide an indication of the gradual increase in liability risk for companies although it should be stressed that this list is by no means complete. The fact that most of these developments emerged within the last few years shows that both operators of sensitive environmental sites as well as the insurance and (to a lesser extent) the banking sector have increasingly to take account of biodiversity-related liability issues.

Table 1. Directives and treaties that affect corporate environmental and biodiversity liability risk

\begin{tabular}{|c|c|c|c|}
\hline Name & Year & Application & Description \\
\hline CBD Article $14(2)^{42}$ & In progress & International & $\begin{array}{l}\text { The Conference of the Parties is examining, on the basis of studies to be carried } \\
\text { out, the issue of liability and redress, including restoration and compensation, } \\
\text { for damage to biological diversity, except where such liability is a purely internal } \\
\text { matter (in progress). }\end{array}$ \\
\hline Directive 2004/35/EC ${ }^{\mathrm{u}, 41}$ & 2004 & EU member states & $\begin{array}{l}\text { The directive aims at preventing environmental damage to water resources, } \\
\text { soil, fauna, flora and natural habitats and at making the polluters pay whenever } \\
\text { damage cannot be avoided. It introduces a liability scheme which will not only } \\
\text { compensate for damage to the environment, in accordance with the 'polluter } \\
\text { pays' principle, but also prevent such damage. When the directive will come into } \\
\text { force as of } 30 \text { April } 2007 \text { operators of risky or potentially risky activities could } \\
\text { be held liable for the costs of preventing or remedying environmental damage. } \\
\text { The future directive also requires Member States to promote the development of } \\
\text { financial security products and encourage operators to take out financial security } \\
\text { cover.v }\end{array}$ \\
\hline $\begin{array}{l}\text { Cartagena Protocol on } \\
\text { Biosafety }{ }^{43}\end{array}$ & 2003 & International & $\begin{array}{l}\text { The objective of this Protocol is to contribute to ensuring an adequate level of } \\
\text { protection in the field of the safe transfer, handling and use of living modified } \\
\text { organisms resulting from modern biotechnology that may have adverse effects } \\
\text { on the conservation and sustainable use of biological diversity, also taking into } \\
\text { account risks to human health, and specifically focusing on transboundary } \\
\text { movements. }\end{array}$ \\
\hline $\begin{array}{l}\text { Protocol on transboundary } \\
\text { environmental liabilityw, } 44\end{array}$ & 2003 & International & $\begin{array}{l}\text { Although attempts to develop an international convention on transboundary } \\
\text { environmental liability did not prove to be successful, a protocol was established } \\
\text { and signed by } 22 \text { countries that will hold companies liable for accidents at } \\
\text { industrial installations, including tailing dams, as well as during transport via } \\
\text { pipelines. The Protocol will give individuals affected by the transboundary } \\
\text { impact of industrial accidents on international watercourses (e.g., fishermen or } \\
\text { operators of downstream waterworks) a legal claim for adequate and prompt } \\
\text { compensation. Physical damage, damage to property, loss of income, the } \\
\text { cost of reinstatement and response measures will be covered by the Protocol. } \\
\text { The Protocol is implemented in the Convention on the Protection and Use of } \\
\text { Transboundary Watercourses and International Lakes. }\end{array}$ \\
\hline
\end{tabular}




\begin{tabular}{|c|c|c|c|}
\hline $\begin{array}{l}\text { OECD Global Forum on } \\
\text { International Investment }{ }^{45}\end{array}$ & 2000 & International & $\begin{array}{l}\text { As a result of four major mining accidents (two in Romania and two in Spain) } \\
\text { between } 1998 \text { and } 2000 \text { recommendations were suggested both for mining } \\
\text { companies as well as public and private financial institutions. A suggestion was } \\
\text { made to develop an international convention on environmental liability which } \\
\text { made not just the operator liable for compensation for damage caused, but also } \\
\text { the provider of the capital. This would imply: } \\
\text { - Compensation for a weak regulatory regime; } \\
\text { - Persuade Fls to insist that the operator (e.g., of the mine) applies the } \\
\text { environmental regulations in its country of origin; } \\
\text { - Persuade Fls to undertake an independent Environmental Impact Assessment } \\
\text { at the outset; } \\
\text { - Attach any other conditions which might be hard for a host country to do; } \\
\text { - Facilitate the postings of bonds to pay for closure and after care; } \\
\text { - Remove pressures to cut "corners" (e.g., in terms of health cover for } \\
\text { employees, environmental safety standards) in favour of jobs. } \\
\text { Note: Though a convention around this theme has not been pursued, it outlines } \\
\text { that major organizations think about extending liability claims also to the } \\
\text { providers of capital. }\end{array}$ \\
\hline Pensions Act ${ }^{46}$ & 1995 & UK & $\begin{array}{l}\text { This legislation, which came into effect in July } 2000 \text {, has proved very powerful } \\
\text { in focusing minds in the financial sector and among companies on the growing } \\
\text { importance of ethical investment. It requires pension funds to } 1 \text { ) disclose the } \\
\text { extent to which they take social, environmental and ethical issues into account } \\
\text { when investing money; and 2) their policy (if any) in relation to the exercising of } \\
\text { rights (including voting rights) attached to investments. It has been regarded a } \\
\text { good example of 'light touch' legislation internationally, with similar approaches } \\
\text { being adopted elsewhere in Europe. }\end{array}$ \\
\hline Fleet Factors Case & 1990 & USA & $\begin{array}{l}\text { In the Fleet Factors Corporation case, the court decided that "a secured lender } \\
\text { could be considered liable for the environmental damage on a borrower's } \\
\text { property if the lender as much as held the capacity to influence the borrower's } \\
\text { waste management decisions, even if it actually did not do so". It was the first } \\
\text { case, in a series of cases, also to hold banks liable for environmental damage } \\
\text { (see Box II). }\end{array}$ \\
\hline $\begin{array}{l}\text { Wildlife and Countryside } \\
\text { Act (amended by the } \\
\text { CROW act, 2000) }\end{array}$ & 1981 & UK & $\begin{array}{l}\text { Owners/occupiers of "Sites of Special Scientific Interest" (SSSIs) convicted of } \\
\text { damaging sites via specified operations, and third parties convicted of reckless } \\
\text { or intentional damage, can be ordered by Court to restore to the former condition } \\
\text { where this is possible. }\end{array}$ \\
\hline Superfund & 1980 & USA & $\begin{array}{l}\text { The Comprehensive Environmental Response Compensation and Liability Act } \\
\text { (CERCLA) also known as "Superfund" reinforced the Environmental Protection } \\
\text { Agency (EPA) in the United States in their effort to clean up contaminated sites. } \\
\text { The act made owners of contaminated sites liable for the clean-ups. Although } \\
\text { lenders (i.e. Fls) were exempted, due to the complexity of the issue, some banks } \\
\text { were forced to enter into the court procedure (see Box II). }\end{array}$ \\
\hline $\begin{array}{l}\text { Clean Water Act and } \\
\text { Endangered Species Act }{ }^{47}\end{array}$ & 1970s & USA & $\begin{array}{l}\text { In order to control water quality and protect endangered species throughout } \\
\text { the United States, two acts were developed: the Clean Water Act }{ }^{\dagger} \text { and } \\
\text { the Endangered Species } A c t^{2} \text {. These acts, however, can hinder economic } \\
\text { development, such as road building or other constructional activities. Certain } \\
\text { US states, most notably California, therefore proposed a more market-based } \\
\text { approach whereby companies are allowed to encroach on wetlands and land, } \\
\text { containing species listed on the Endangered Species List, if the damage this has } \\
\text { caused is being offset. The two types of markets that were created in this way, } \\
\text { and really took off in the last couple of years are Wetland Mitigation Banking and } \\
\text { Conservation Bankingaa. Currently, these markets comprise a market volume of } \\
\$ 290 \text { million and } \$ 40 \text { million. }\end{array}$ \\
\hline
\end{tabular}

u See http://europa.eu/bulletin/en/200403/p104056.htm (consulted October 2006).

$\mathrm{v}$ This directive was approved by the European Parliament and Council on 31 March 2004. Information can be found here: http://europa.eu/bulletin/en/200403/p104056.htm

${ }^{\mathrm{w}}$ It concerns a protocol to the Convention on the Protection and Use of Transboundary Watercourses and International Lakes and the Convention on the Transboundary Effects of Industrial Accidents.

${ }^{\mathrm{x}}$ From the overview of existing environmental liability schemes in the UK: http://www.defra.gov.uk/environment/liability/ index.htm

$\mathrm{y}$ The Wetland Mitigation Banking phenomenon was made possible because of the Clean Water Act 1972 Chapter 404(b)(1), giving it a legal basis and the US Army Corps of Engineers regulations (33 CFR 320.4(r).

${ }^{\mathrm{z}}$ Conservation banking could be developed because of the Endangered Species Act 1973. Furthermore, see the Guidance on Establishment, Use and Operations of Conservation Banks (http://endangered.fws.gov/policies/conservationbanking.pdf). aa Other legal requirements include: Habitats and Birds Directives in the EU, 1992; offsets in Brazil under the Forest Regulation and National System of Conservation Units, 2000; Federal law for the protection of nature and landscape in Switzerland; offsets in Australia; no net loss of fisheries habitat in Canada under the Fisheries Act, 1986. 


\section{Box II. The Fleet Factors Corporation case}

A court decision in the 1990 Fleet Factors Corporation case that "a secured lender could be considered liable for the environmental damage on a borrower's property if the lender as much as held the capacity to influence the borrower's waste management decisions, even if it actually did not do so", was the first case that eroded the security that was given to Fls under the Superfund in 1980 ("to exempt lenders from holding them liable for environmental damage").

Following the Fleet Factors decision, a survey conducted by the American Bankers' Association found that $63 \%$ of US commercial banks rejected loan applications because of possible environmental lender liability. Subsequently $46 \%$ of banks in this group have discontinued financing sectors considered to be environmentally risky, such as chemical facilities or service stations.

Source: Business and Sustainable Development: A Global Guide (www.bsdglobal.com).

\subsubsection{Legal and social license to operate}

As biological diversity is continuing to decrease around the world, governments are putting ever stricter regulations such as laws and limitations on the use, trade and conservation of biodiversity. This may affect the financial sector in two ways. Indirectly, it may affect financial institutions when companies in which they hold shares or which have debt face stricter regulations. This may consequently lead to increased costs or even lower investment returns. Directly, it may affect FIs when they are forced themselves to screen, manage and report on biodiversity-related issues.

The recently launched "Potsdam Initiative - Biological Diversity $2010 " 1$ is such an example of legal license to opeate. The environment ministers of the G8 countries and the five major newly industrializing countries outline in this initiative that they will "approach the financial sector to effectively integrate biodiversity into its decision making". Also, Portugal, which will hold the next EU presidency (second half of 2007), indicated their appetite for management systems to mainstream biodiversity in the private sector. $^{48}$

On another note, an article on the Forbes website 3 May $2007^{49}$ announced that Credit Suisse has been urged by indigenous groups from Guyana, Cambodia, Malaysia, and Papua New Guinea to pay them US $\$ 10$ million in compensation, because of their link to the Malaysian timber company Samling. This company retained Credit Suisse as an adviser during its stock market flotation in February, along with HSBC and Australian bank Macquarie. The indigenous peoples claim that Samling's operations have damaged their communities by cutting down forests and in some cases, polluting sources of drinking water.This highlights the importance for FIs such as banks to also take into account their social license when doing business.

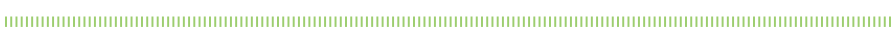

"COMPANIES JUST CANNOT IGNORE SHAREHOLDERS WHEN THEY SHOW THEIR CONCERNS. MEDIA ARE VERY IMPORTANT IN THis ReSPeCt (E.g. SEE THE RAINFOREST ACtion Network CAmpaigning that led to the Equator Principles).” Chris Fox, CERES

\subsubsection{Reduced shareholder value}

Without identifying a clear link between environmental improvement and the financial bottom line, the financial sector itself will remain sceptical and reluctant to encourage companies to improve their environmental performance. Over the last few years this link, however, is becoming clearer and is increasingly recognized by key players in the financial sector. Nowadays, the shareholder value of a company is also determined by extrafinancial issues, such as governance and environmental issues.

An increasing number of institutional investors are becoming interested in approaches to asset management that explicitly include environmental criteria.Although clearly not always the case this means that reputational risk, liabilities, concerns by policy makers, etc. may have an effect on how shareholders value a company and therefore have an effect on a company's stock. Since share prices in financial markets are core to any major business that is present at a stock exchange, lower ratings may therefore very well be the most direct and significant risk investors face with respect to environmental and biodiversity issues. Vice versa, better stock ratings provide clear evidence that proper accounting of environmental issues by a company can also impact shareholder value for the better.

A few cases and trends are shown below to highlight how they can lead to positive or negative performances by a company's shareholder value. It uses the hypothesis that attention for sustainability issues lead to better performance. However, when turning around that hypothesis one could say that companies that outperform are more professional companies, which automatically pay more attention to sustainability issues including environmental and biodiversity considerations.

Note: The cases that are presented below are divided in "positive performance" and "negative performance" and do not always link specifically to a company's biodiversity performance. Rather, words like "environment" (which includes biodiversity), "CSR" or "sustainability" (of which environment and biodiversity are part) are used.

\subsubsection{Evidence of positive performances}

- On an aggregated scale, the Dow Jones Sustainability Group Index shows that proper accounting of sustainability issues does not necessarily mean less financial performance as it has out-competed its elder brother, the Dow Jones Group Index, in the past few years (see Box III).

- A study by Innovest focused on the performance history of over 300 "Fortune 500" companies and found similar evidence. This study showed that highest-rated companies outperformed their competitors by as much as $5 \%$ and often in the range of $2-3 \%$. This, Innovest claims, is because there is a strong correlation between environmental management and overall performance: A company that pays attention to the former is more likely to be well-managed overall..$^{50}$

- Another study by UK's Environmental Agency, together with Innovest, tried to find evidence on the link between environmental governance and financial performance of companies. ${ }^{51} \mathrm{~A}$ detailed literature review of 60 studies (from business, academia, NGOs and government) revealed a positive correlation between environmental governance and financial performance in $85 \%$ of the studies. The sectors reviewed comprised: oil \& gas, EU and US electric utilities, paper \& forest products and water products.

- In line with this, a World Bank study Capital market responses to environmental performance in developing countries, focusing on Argentina, Chile, Mexico and the Philippines, assessed whether stock markets in these countries react to the announcement of firm-specific environmental news. They found that stock markets react positively (increase share prices) to the announcement of rewards and explicit recognition of superior 
environmental performance. However, the authors also show that capital markets react negatively (lower share prices) to citizens' complaints. ${ }^{52}$

\subsubsection{Evidence of negative performances}

The cases shown below are all related to non-FI companies. They are nevertheless interesting for investors and asset managers:

- Associated British Ports was immediately penalized by its shareholders for not appropriately taking into account biodiversity issues in its management plans to develop a new port in Dibden Bay, near Southampton (see Box IV).

- A study by WRI investigated how constraints on two major environmental issues for the oil \& gas sector have impacted on their respective sales, operating costs, asset values and shareholder value. The two environmental issues concern 1) climate change; and 2) restricted access to oil \& gas reserves. A previous study by the WRI stated that "three quarters of active mines and exploratory sites overlap with areas of high conservation value and areas of high watershed stress". ${ }^{53}$ The likely loss in shareholder value that 16 major oil \& gas companies face because of presence in pristine or protected areas lies in the range of $2-6 \% .^{54}$

- Gupta and Goldar (2005) ${ }^{55}$ found evidence from India where capital markets generally penalize environmentally unfriendly behaviour in that announcement of weak environmental performance by firms leads to negative abnormal returns. 17 pulp and paper companies, 15 companies in the automotive sector and 18 companies in the chlor-alkali sector were given a green rating by India's leading NGO, the Delhi-based Centre for Science and Environment (CSE). This rating was consequently announced after which the impact of this announcement on the company shareholder was measured at the popular Bombay Stock Exchange. Although not all companies received the same rating in this study, it can generally be concluded that companies that received a bad "green" rating (i.e. negative environmental performance) encountered negative abnormal returns in the pulp \& paper sector of up to $30 \%$ and in the chlor-alkali sector of up to $11 \%$. No relation was found for companies in the automotive sector.

\subsubsection{Reputational risk}

Reputation is one of the most highly prized assets of a company. It is also an intangible asset, difficult to capture and quantify.A survey by the Economist Intelligence Unit ${ }^{56}$ among 269 senior executives (CEOs, CFOs and chief risk officers) revealed that reputational risks was regarded as the most important type of risk (even more important than regulatory risk, human capital risk, market risk or credit risk). $37 \%$ of the companies in the survey were financial institutions.

Non-compliance with regulatory obligations was seen as the biggest source of reputational risk that a company faces. However, "poor crises management" (e.g., as a result of NGO campaigning), "exposure to unethical practices", "failure to address matters of

\section{Box III. Sustainability can pay off as shown by evidence from the Dow Jones Sustainability World Index}

The Dow Jones Sustainability World Indexes (DJSI World) cover the top $10 \%$ of the biggest 2,500 companies in the Dow Jones World Index in terms of economic, environmental and social criteria. Three criteria are included that focus specifically on the environmental sustainability of companies: environmental performance (eco-efficiency), environmental reporting, and industryspecific criteria.

The 2006 review featured 318 companies and 58 DJSI. 46 companies were added to the index, while 36 companies were removed. With respect to financial services, Westpac Banking Corporation was appointed as a Global Sector leader in the banking sector, while Investa Property Group was appointed sector leader in (other) financial services.

The two charts present an interesting finding. While chart 1 shows that there is a (logical) out-performance of DJSI members compared to non-members on a number of sustainability criteria that have been included, chart 2 shows that companies, on an aggregated scale, that take sustainability seriously (which is something that can be assumed when a company is included in the DJSI) have received higher ratings compared to companies listed on the DJ World Index.

Chart 1 also shows that for the criterion "sustainability and project finance", mainly subject to banks, DJSI members score significantly better than non-members. Similarly, for the criterion "protection of biodiversity", especially subject to the oil \& gas sector, DJSI members score significantly better than non-members.

Source: Sustainable Asset Management (SAM), 2006; DJSI website (www.sustainability-indexes.com) consulted October 2006.
Chart 1. Average sustainability scores for selected criteria: DJSI members and non-members

Average sustainability scores for selected criteria DJSI members and non-members

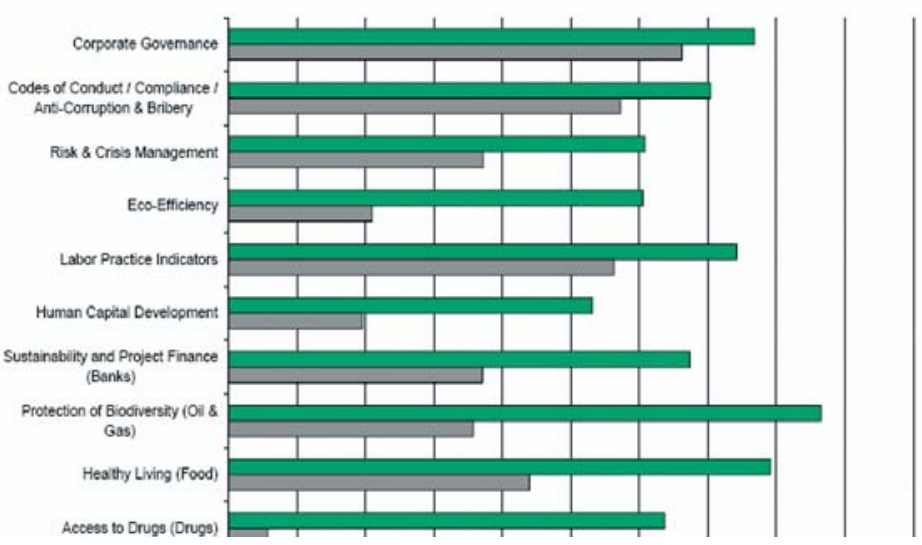

Chart 2. DJ Sustainability Index vs DJ World Index

DJ Sustainability World Index

DJ World Index

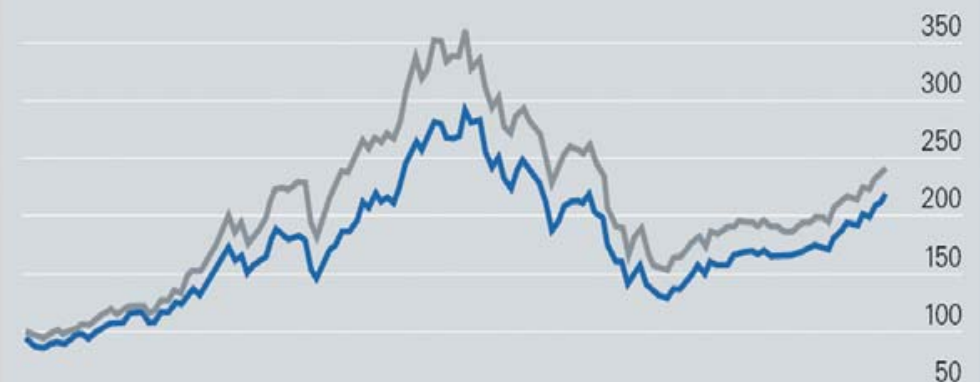


public concern" (e.g., climate change or biodiversity conservation), and "environmental breaches" (i.e. liability) can all be attributed to environmental concerns depending on the subject.These were regarded important as well (Figure 9).

Although this survey did not specifically focus on biodiversity, it does provide an indication that environmental issues (or actions that have an environmental cause) are being recognized by the senior management.

Though difficult to quantify the reputational risk for FIs these following cases provide evidence that outside influences may have an effect on FIs:

- In April 2005, for example, demonstrations held in front of the offices of JPMorgan Chase, the second largest bank in the US, led to the introduction of policies promoting sustainable forestry and indigenous people's rights, as well as the allocation of funding to fight illegal logging. The protests related to the bank's underwriting of forestry practices in Indonesia and alleged human-rights abuses tied to a JPMorgan Chase-funded mining operation in Peru.

- One of the reasons why Citigroup backtracked on funding for an oil pipeline planned to go through old-growth forests in Ecuador may be the fact that an NGO ran an advertisement in the International Herald Tribune labelling the CEO of Citigroup an 'environmental villain'.

- ING Group has withdrawn support from an investment project by the Finnish company Botnia to build pulp mills in Uruguay. The project has been under scrutiny, among others from local communities. Although it remains speculation, a lack of social license to operate and potential reputational scrutiny could have contributed to ING's decision to withdraw from this project (Box V).

- Barclays, one of the banks that participated in the initial development of the Equator Principles, came under scrutiny in the end of 2003 for providing a $\$ 400$ million loan to the $\$ 1$ billion project to build a series of dams in the east of Iceland. ${ }^{57,58,59}$

In addition, evidence from the oil \& gas sector suggests that insufficient accounting for environmental and biodiversity issues by companies and its investors can lead to reputational damage and impacts on financial return for investors and commercial banks (Box VI).
Figure 9. The extent to which these actions a source of reputational risk for companies

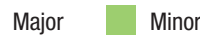

Non-compliance with regulation/legal obligations

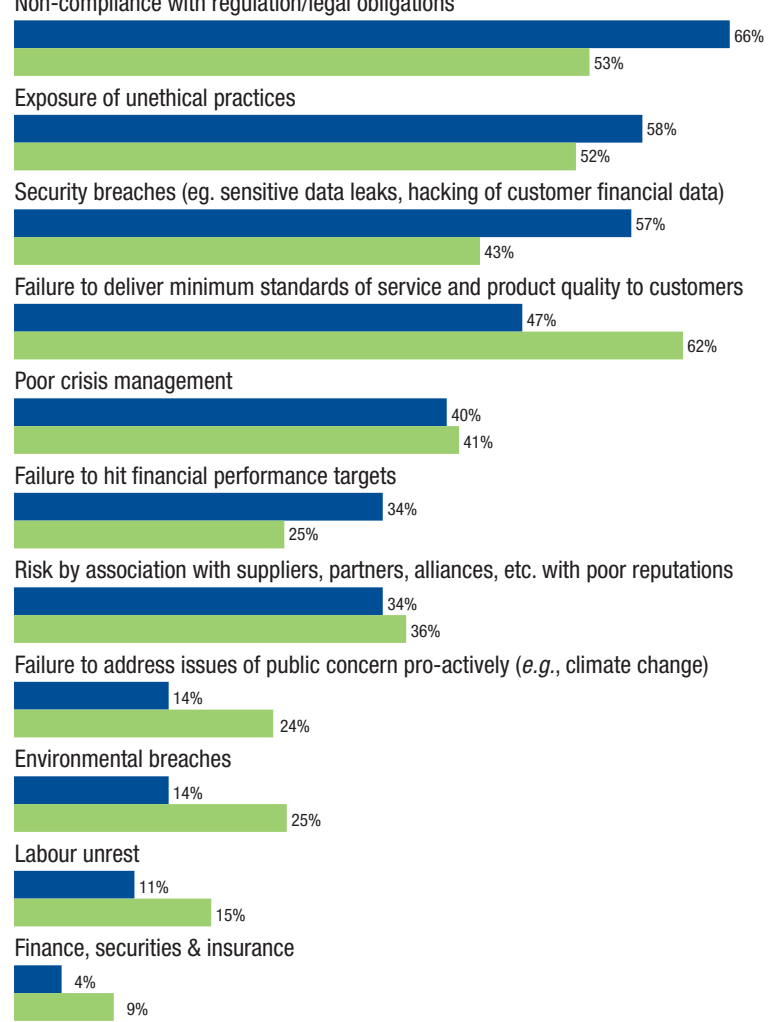

Source: Economist Intelligence Unit. ${ }^{56}$

\section{Box IV. The case of Associated British Ports}

Associated British Ports (ABP), Britain's largest port operator, saw GBP155 million wiped off its market value after the UK government blocked the company's plans for a new container terminal at a site in the south of England in April 2004.

Shares in the company fell by 47 pence following the announcement, a fall of almost $10 \%$ in a single day. The company's plans were for a deep water terminal at Dibden Bay, near Southampton. These were rejected after opposition from campaigners, who claimed it would wreck important wildlife locations. The government admitted that one major factor in its decision was the potential environmental impact of the company's plan for the terminal. Although the share price of ABP has recovered since, such a case demonstrates clearly that environmental issues are often inextricably linked to business strategies.

Source: UK Environmental Agency, 2004. Corporate Environmental Governance. A study into the influence of Environmental Performance and Financial Performance. Environment Agency, Bristol, United Kingdom; Innovest, Cleveland, USA.

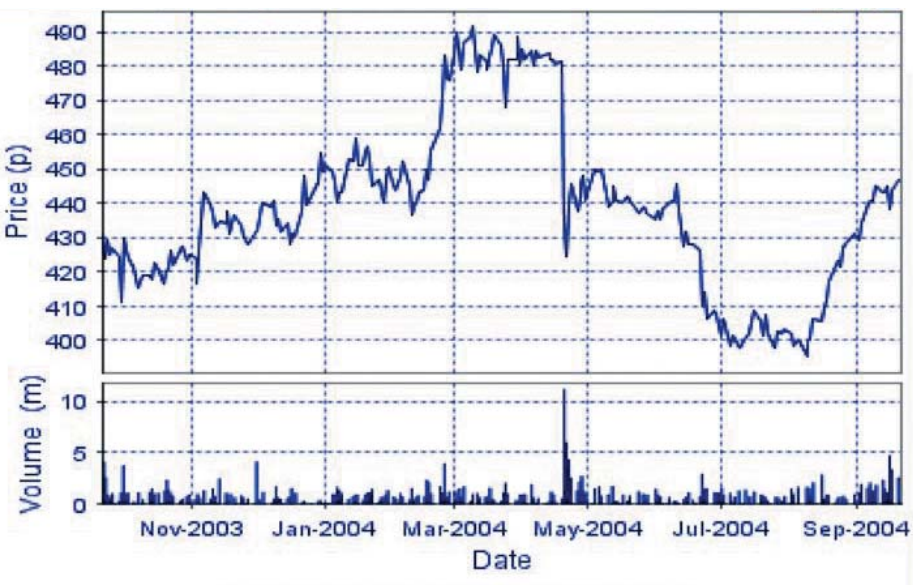

Associated British Ports Holdings PLC 


\subsection{How do these drivers for biodiversity risk add up?}

It is difficult to estimate, let alone calculate, the aggregated risks related to biodiversity that financial institutions are exposed to, based on the anecdotes, scientific papers, trends and other examples stated in this chapter.

However, the cases and trends provided in this chapter point out that biodiversity cannot be ignored either. Given the fact that global biodiversity resources are expected to decline further in the near future, increased pressure for tighter regulations from governments, consumers (especially in industrialized countries) and NGOs can be expected towards companies impacting on ecosystems.

In addition an interview survey among 25 FIs and other stakeholders also attempted to understand the FI's willingness to be better equipped to identify, address and mitigate biodiversity risks through their risk management procedures or other business operations. Though a few FIs appeared neutral, most of them clearly expressed their interest in having a tool developed that would enable them to take better account of biodiversity considerations within their business operations. However, such an instrument should carry broad consensus, be easy to implement in existing (environmental) risk structures, be quick to use (a client's presumed biodiversity impact should be quickly assessable) and the information, used as input for the instrument, should be readily available.

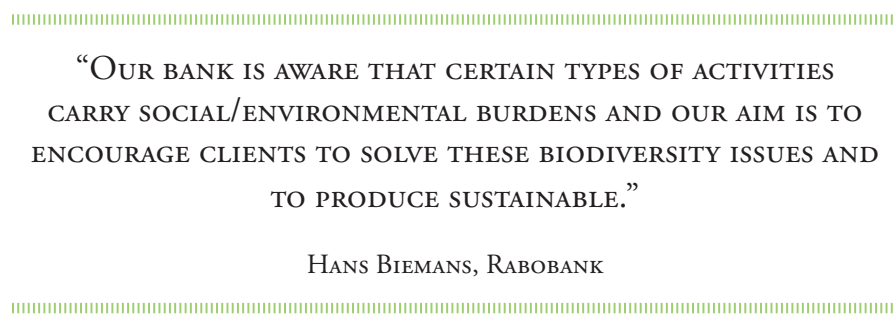

\section{Box V. Reputational risk, a motivation for a financial institution to pull out of paper mill projects in Latin America? The case of ING Bank and Botnia in Uruguay}

\section{The dispute}

The Finnish company Botnia wants to build pulp mills across the banks of the Uruguay River in Fray Bentos, making it the single largest direct foreign investment in Uruguay ever. The project is financed by a syndicate comprising the Dutch bank ING Group and the World Bank's private arm IFC, amongst others.

The project has come under scrutiny because of strong feelings that environmental pollution from the factories will damage agriculture and local (naturebased) tourism in Argentina. ING Group, which coordinated about $40 \%$ of the loan, in this $\$ 1.2$ billion project has pulled out of the project. This may have been caused by pressure from outside environmental organizations as well as the Argentinian government, which strongly opposed this project saying the "...mills posed a serious threat to the ecosystem of the River Uruguay". Along this line, BBVA, a Spanish bank, has also come under pressure to withdraw its support from plans by Ence, a Spanish company that wants to build another mill in the same town.

Although difficult to verify, the most likely reason for ING pulling out was the importance of its image as a responsible investor (ING Group has signed the Equator Principles) as well as risks generated by the conflict between the governments of Argentina and Uruguay.

\section{At present}

ING's role has been taken over by the French investment bank Calyon, who stresses that it will only remain involved if the IFC concludes that the pulp mills comply with international environmental standards. However, on November 23 the IFC acknowledged that Botnia, the owner of the Orion paper mill, will receive a US\$170 million loan. In addition, it will receive a US\$350 million loan guarantee from the World Bank's Multilateral Investment Guarantee Agency (MIGA). Notwithstanding, local communities continue to oppose the paper mill, which indicates that there is no social license to operate the paper mill making it more difficult to have it operating in a favourable economic environment. The Argentinian government, meanwhile, requested the International Court of Justice in The Hague for the indication of provisional measures (23 January 2007) referring specifically to "to the effects of such activities on the quality of the waters of the River Uruguay and on the areas affected by the river".

Pending the court's final judgment, Uruguay is requested to suspend and withhold all work on the two pulp mills and cooperate with Argentina to protect and preserve the aquatic environment and to prevent its pollution.

Source: Financial Times, 9 and 26 June 2006 ('Green' dispute means trouble for investors at Uruguay mills; Planting forests of opportunity); Environmental Finance, 23 November 2006; International Court of Justice (http://www.icj-cij.org). 


\section{The Sakhalin-2 pipeline in Russia's far Southeast}

Sakhalin, a South-eastern Russian island, is home to the world's biggest liquefied natural gas development and could eventually pump up to 140,000 equivalent barrels of oil per day. Sakhalin-2, as the project is called, is a US\$20 billion project involving Royal Dutch/Shell together with the Japanese project partners Mitsui and Mitsubishi and led by Russia's state oil company Gazprom.

In 2005 Shell gave a warning that the project costs would double from about US $\$ 12$ billion to about US $\$ 20$ billion because of the rising cost of raw materials, a shortage of contractors, Russian inflation and currency exchange rate fluctuations. In addition to this, Shell was forced to re-route a key pipeline in phase II of the project, because it threatened the western grey whale population of which only 120 individuals are thought to remain in existence. Re-routing of the offshore pipeline is estimated to have cost more than US $\$ 300$ million. Due to allegations of damage to Sakhalin's rivers and forests, the environmental permit that was issued in 2003 was reinvestigated in September 2006.

As a result, the project has been criticized by Russian state auditors because of cost overruns thought to be worth at least US\$8 billion. Such a move would affect Russia's profit from the venture, since Sakhalin-2 has been developed under a production-sharing agreement making any cost increase delay the moment when Russia starts profiting from the project.

Gazprom, the state-controlled gas monopoly, agreed to take a shareholding in the project in 2005. As it appears, the Kremlin is using environmental concerns to gain control over the Sakahlin-2 project, as the project started without any Russian participation. It was apparent that inadequate recognition, accounting and management of the environmental and biodiversity impacts of the Sakhalin-2 phase II project by the Shell-led consortium might have led to major implications on estimated project revenue for both Shell, its partners as well as for the investors (e.g., the European Bank for Reconstruction and Development (EBRD)).

Source: Financial Times, March 31, December 15, 2005; September 26, 29, 2006; Quaile, personal communication.

\section{The OCP pipeline in Ecuador}

The construction of the OCP Pipeline in Ecuador, which was completed in 2003, is no doubt the most heavily criticised project financed by WestLB. The 480 $\mathrm{km}$ (300 mile) pipeline leads from the rain forest in the east of Ecuador to the Pacific coast.

According to various environmental and north-south organizations (e.g., Urgewald E.V.) the route chosen for the pipeline is a hazard to numerous protected areas, among other things because it leads through the cloud forest of the Mindo-Nambillo reserve, which ecologists consider to be the most important bird reserve in South America. Moreover, they claim that indigenous peoples in the Amazon have been deprived of their land and their resources and exposed to serious health hazards.

WestLB agrees with the NGOs that this was a high-risk project. In accordance with its currently applicable internal procedures, much greater attention would be paid to upstream and downstream activities such as the exploration of oil. The bank nevertheless points out that various environmental protection measures were already taken during the implementation of the project, which were exclusively attributable to the voluntary commitment of OCP and the initiative taken by WestLB. Nonetheless, the case points out that banks increasingly need to be aware what type of projects and companies they are financing in order not to harm their corporate reputation. 
$\operatorname{sic}|>|>|>|$ 1. S Jos

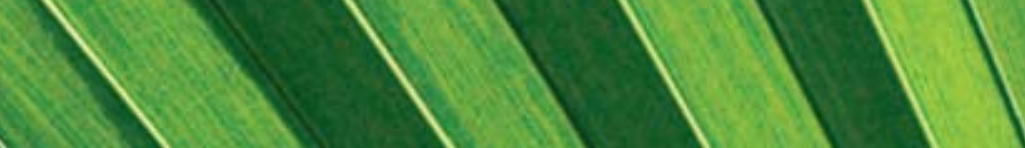
1050 S.
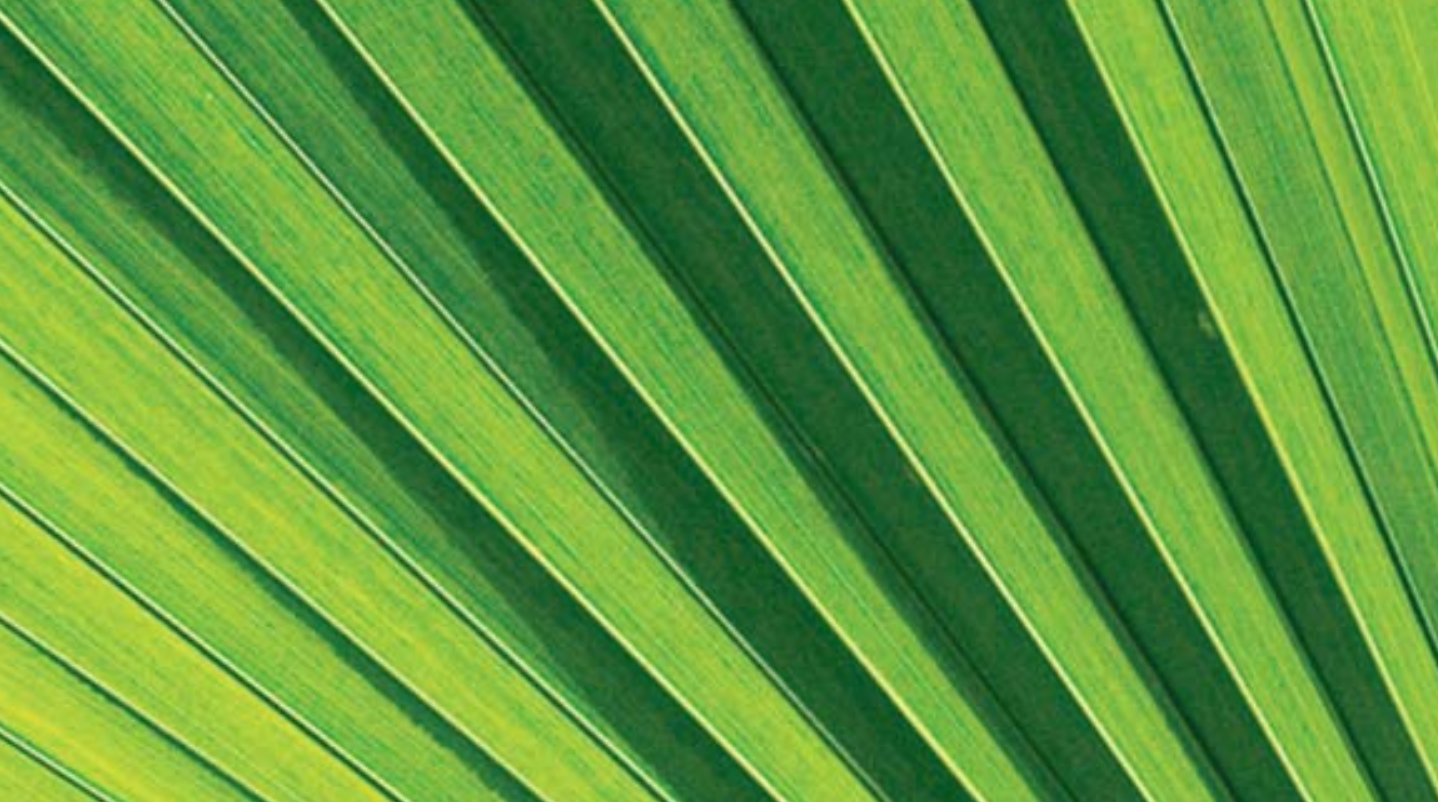


\section{Assessing biodiversity business risks for commercial banks, asset managers and insurers}

Where the previous chapter focused on what types of BBRs the financial sector is facing and what evidence is available to back this, this chapter will go into more detail to see how retail and commercial banks, asset management, and (re)-insurance firms can be exposed to BBRs. This way of dividing the financial sector is for example also used by the Global Reporting Initiative ${ }^{60}$, though it is recognized that these segments do not cover the full financial sector. However, both this chapter as well as the previous one are also useful for other types of financial institutions, most notably private and institutional investors. Section 4.1 outlines a number of factors that can contribute to differences in risk exposure for different types of financial institutions. Sections 4.2-4.4 provide further details of what this means for each type of FI.

\subsection{Biodiversity risks can differ within the financial sector}

Not all financial institutions face the same level of biodiversity risks (and opportunities). There are a number of factors that determine to what extent a financial institution is prone to biodiversity-related risks. These may include:

- Core activities. Not one FI is the same. When looking, for example, specifically within the retail and commercial banking sector it might depend whether a bank is prone to potential biodiversity liabilities, or whether it is focusing its activities on retail or commercial clients. Certain financial services are more closely linked to clients and projects that could result in biodiversity risk than others. A bank with a major project finance department for example has different clients, a different control over a loan and therefore a different level of risk exposure compared to banks that are involved in retail banking. This can be similar to asset managers and (re)insurance companies.

- Type of clients. A FI increases its level of exposure when it becomes more directly involved in businesses that face considerable risk. FIs that invest in, provide loans for or (re)insurance products to high impact sectors, such as companies in the forestry \& paper sector, are logically at greater risk than FIs that have invested in or provided loans to low impact sectors such as IT. F\&C ${ }^{34}$ has outlined which are high risk sectors, based on the proportion of companies likely to be exposed to BBRs and the significance of risks faced by individual companies in the sector (see Table 2).

Table 2. High risk sectors listed on the FTSE indices according to biodiversity risk exposure

\begin{tabular}{|l|}
\hline Red zone: High-risk sectors \\
\hline Construction \& Building materials \\
\hline Electricity \\
\hline Food \& Drug retailers \\
\hline Food Producers \& Processors \\
\hline Forestry \& Paper \\
\hline Leisure \& Hotels \\
\hline Mining \\
\hline Oil \& Gas \\
\hline Utilities \\
\hline
\end{tabular}

- Client recognition of biodiversity-related risks. Other than the issue of financing high impact sectors, there are also great differences in how companies within a given sector address and manage biodiversity.A mining company such as Rio Tinto for example, which has stated that its business activities need to have "a net positive effect on biodiversity" ${ }^{47}$ can be recognized as "best-in-class" example within its sector.Therefore its creditor or insurer is logically less likely to be prone to biodiversity risks than clients that fail to do so.

- Visibility. Visibility and a company's reputation are highly related. FIs, such as banks, that are more visible to the general public, policy makers and other stakeholders are more likely to be at risk than companies that are less publicly visible (e.g., export credit agencies).

The following sections will briefly focus on how biodiversity risks can emerge for retail and commercial banks, asset management, and (re)insurance. Please note that a considerable number of large financial institutions cover all of the above mentioned segments, so-called universal banks. ${ }^{\text {bb }}$

\subsection{Commercial and retail banking}

Retail banking involves the provision of commercial and private banking services to individuals, such as offering loans, making investments and transmissions. Commercial banking involves all transactions with organizations and business counterparts of all sizes. The types of services that are offered include, but are not limited to: Corporate banking, project and other types of structured finance, transactions with small and medium-sized enterprises (SMEs) and the provision of financial services to governments. It also includes corporate advisory services, mergers and acquisitions, equity/debt capital markets, and leveraged finance (i.e. lending money for transactions).

Note: The focus on this report has been put on commercial/corporate banks, as BBRs can foremost be expected from a bank's activities with commercial corporations, rather than with its retail clients.

The only true rationale for banks to factor-in environmental considerations, other than regulatory obligations, is when 1) environmental issues have an impact on a client's ability to pay back a loan - default risk; 2) security of an asset used as collateral; or 3) when it is directly held liable for environmental pollution (direct liability risk). Other than that, impacts on a bank's reputation and shareholder value (e.g., investors demanding good environmental practices by the bank in which it invests) are also factors that enhance the interest of commercial banks in ecosystems from a risk perspective.

\subsubsection{Environmental risk management by commercial banks} About 15 years ago the first European and US banks started to integrate environmental considerations into their credit-lending activities. ${ }^{4}$ While a lot of banks are struggling to integrate overall environmental risks into their lending activities ${ }^{5}$, recent analysis indicates that more and more banks integrate these considerations into their credit risk management procedures. ${ }^{6,7}$ Typically, environmental considerations are considered in the early risk identification phase of the credit risk management process. ${ }^{8}$ Banks factor-in environmental risks to a different degree, ranging from merely acknowledging environmental risks on the sideline to fully integrating environmental risks in the whole credit risk management process. 
ISIS Asset Management evaluated the Environmental Credit Risk Assessment (ECRA) policies of 10 banks in its Pan-European portfolio in 2002. The purpose of the study was to benchmark those 10 companies and enable ISIS to evaluate the potential impact of such practices on profitability and ultimately shareholder value ${ }^{40}$ (Table 3 ). Banks that participated were judged on both their written policy on ECRA and the degree to which such policies have been operationalized.

The differences in ECRA policies between the 10 banks are justified by the fact that the "starting grid" banks have just recognized the relevance of ECRA, while the "chasing pack" banks have established internal ECRA policies and have started to apply these policies in operating procedures in selected products. "Race leaders" can point to relatively mature and detailed review policies, training systems and communications.

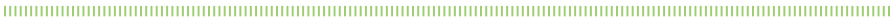

"BESIDES PROJECT FINANCE, LONG-TERM EXPORT FINANCE / COMMODITY FINANCE WOULD BE ANOTHER TYPE OF SERVICE WHERE IT IS POSSIBLE TO ACCOUNT FOR BIODIVERSITY RISKS.”

$$
\text { Foster Deibert, WestLB AG }
$$

Most large banks apply due diligence to loans, these days, when there is reason to believe that impacts on the environmental may be significant. The Swiss bank UBS for example applies due diligence to identify (environmental) risks at an early stage. When it appears that no significant negative impacts on the environment are expected the analysis is finalized. When the environmental risks cannot be ruled out a more detailed environmental assessment will be carried out. Such an assessment can use international standards (e.g., the environmental policies developed and applied by the World Bank and the IFC). Should there remain reason for concern, UBS outlines that it may either 1) adapt the terms of the loan contract;2) engage in a dialogue with its client; or 3) decline the transaction altogether. ${ }^{61}$ The European Bank for Reconstruction and Development (EBRD), which can be regarded as a bank under public law, does the same, but explicitly states that it uses national and international best practice in the areas of ecology, worker protection and local communities in all their loan activities. In addition the EBRD uses an "exclusion list" to refrain from financing certain activities or engage in certain sectors. ${ }^{62}$ Other banks have adopted the bank's extensive environmental guidelines as well.

\subsubsection{How can commercial banks be exposed to biodiversity risks?}

Generally speaking biodiversity is no different from other environmental (or social) issues. It only becomes truly material to banks when it impacts on a bank's reputation, credit risk, collateral, liability risk or when new regulations are imposed by a government. Taking into account these types of risks, it is worthwhile assessing what factors contribute to a certain type of financial product or service to be exposed to BBRs and what factors contribute to a bank's ability to respond to it. Factors that contribute to the exposure of BBRs include (but may not be limited to):

- Timeline of the loan. Loans with larger timelines have to take account of more extra-financial issues compared to loans or other financial services that operate on shorter timelines.

- Non-recourse. When the pay-back of a certain loan is fully determined by the revenue generated by a specific activity/ project (i.e. non-recourse ${ }^{c c}$ ) there is a greater need to look beyond conventional types of risks and also take into account biodiversity considerations when the impacts on ecosystems are thought to be substantial.

- Link to environment/ecosystems. Banks that provide loans to companies that operate in sensitive ecosystems and that have profound impacts on these systems naturally face greater risks than those who finance companies in the IT sector. Project finance is often related to high impacts on ecosystems as they typically concern infrastructural or energy projects.

Table 4 provides a preliminary overview of how these factors may influence the extent to which different types of loans and other financial services are exposed to biodiversity risks.

cc This is a lending arrangement, where the lender or creditor is not permitted to request repayment from the parent company (i.e. debtor)

if the borrower (its subsidiary) fails to meet their payment obligation.
Table 3. Benchmarking of ECRA policies of 10 European banks ${ }^{40}$

\begin{tabular}{|l|}
\hline Race leaders \\
\hline $\begin{array}{l}\text { Barclays } \\
\text { Credit Suisse Group } \\
\text { Lloyds TSB }\end{array}$ \\
\hline Chasing pack \\
\hline $\begin{array}{l}\text { HSBC } \\
\text { ING Group } \\
\text { Royal Bank of Scotland } \\
\text { Standard Chartered }\end{array}$ \\
\hline Starting grid \\
\hline $\begin{array}{l}\text { Santander Central Hispano } \\
\text { Société Générale } \\
\text { UnoCredito Italiano }\end{array}$ \\
\hline
\end{tabular}

Table 4. How different services and products by commercial banks may be prone to biodiversity risks

\begin{tabular}{|c|c|c|}
\hline Type of service & Characteristics & Type of risk \\
\hline Corporate finance & $\begin{array}{l}\text { Banks with large portfolios of } \\
\text { companies that have a profound } \\
\text { impact on ecosystems might be } \\
\text { at risk, especially when the loan } \\
\text { contract extends over a considerable } \\
\text { period. }\end{array}$ & $\begin{array}{l}\text { - Credit risk/non-performing loans } \\
\text { - Reputational risk }\end{array}$ \\
\hline $\begin{array}{l}\text { Specialized/structured } \\
\text { finance }(e . g .) \text { : } \\
\text { - Project finance } \\
\text { - Export credit }\end{array}$ & $\begin{array}{l}\text { In case of recourse projects, for } \\
\text { example project finance, a bank has a } \\
\text { sound reason to back-up all possible } \\
\text { risks including the biodiversity-related } \\
\text { ones. But also for other types of } \\
\text { specialized finance, such as export } \\
\text { credit, biodiversity considerations can } \\
\text { be factored-in. }\end{array}$ & $\begin{array}{l}\text { - Reputational risk } \\
\text { - Regulatory constraints } \\
\text { - Credit risk }\end{array}$ \\
\hline
\end{tabular}




\subsubsection{Has biodiversity appeared on the radar screen of the commercial banking sector?}

A report by Oxera $^{63}$ in 2000 identified the extent to which a number of private sectors, including the banking sector, were engaged with performance measurements of biodiversity. It shows that at the time the report was released the banking sector scored worst out of four sectors; below 5\% (Figure 10).

A report by F\&C Asset Management in $2004^{34}$ provided an indication of how the issue has rooted in the financial sector in the UK. The study used the Environment Index (previously named the Business in the Environment Index - BiTC $\left.{ }^{\mathrm{dd}}\right)^{64}$ as an indicator to assess whether companies in these sectors are addressing biodiversity. Companies that identified biodiversity as one of their most "significant impact areas" could fill out the biodiversity section of the questionnaire. It turned out that of the 96 financial institutions that are listed on the FTSE350 Index, 34 decided to complete the Environment Index questionnaire and of these 34 companies, about $12 \%$ completed the biodiversity question in the questionnaire. This means that on a national scale the issue has hardly appeared on the radar screen of banks and other FIs. ${ }^{\text {ee }}$

It is known, however, that next to alternative banks (which consider a positive influence on the environment as part of their strategy and business operations such as the Dutch-based ASN Bank) the issue is starting to be recognized by a number of large international banks as well. To get a feeling for how biodiversity has been addressed by these companies at present an assessment has been conducted of 11 commercial and investment banks (Table 6). These banks were chosen for their global reach and/or involvement in the development and adoption of the Equator Principles. Furthermore these banks represent about $17 \%$ of total assets in the commercial banking sector worldwide (Table 5), ${ }^{65}$ which provides a potentially huge influence of any biodiversity-related policies on their corporate clients (please note that Goldman Sachs, which is an investment bank, has been included as well).

The following information sources were part of this process: 1) expert consultations; 2 ) company websites (specifically the sections on environment and sustainability);3) annual CSR/ Sustainability reports; and 4) other publicly available reports or guidelines.

The review provides information on the following indicators, which are elucidated in Table 6:

- Annual sustainability (CSR) reports;

- Environmental risk standard or environmental policy;

- The Equator Principles (EPs) and how they are implemented by these companies - Figure 11 (and Box VIII). The EPs follow the IFC performance standards, which includes Performance Standard 6 on Biodiversity Conservation and Sustainable Natural Resource Management, to which the banks must adhere themselves.

- Sector-specific guidelines that have been developed and adopted by the institution itself to factor-in social and environmental guidelines in certain sector-specific loan and investment activities.
Figure 10. Average percentage score for engagement with and action on biodiversity ${ }^{63}$

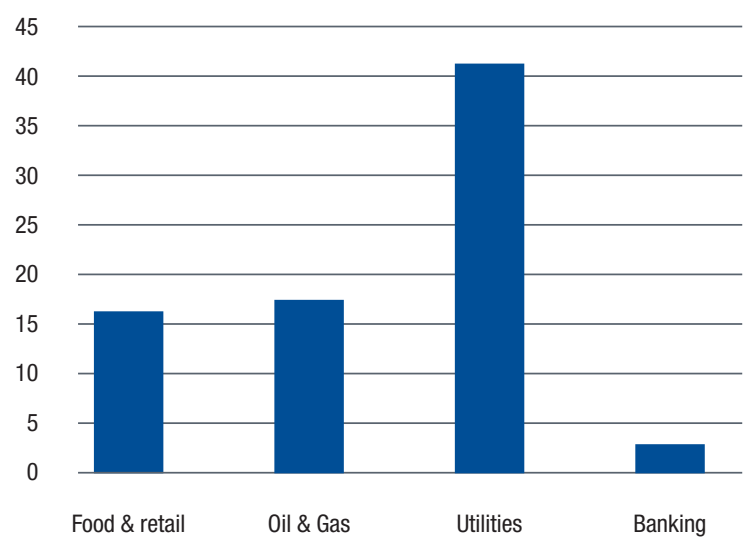

Table 5. Banks that are covered in the assessmentf

\begin{tabular}{|l|r|}
\hline Bank & Total assets (US\$ million) Dec. 2006 \\
\hline ABN Amro & $1,038,970$ \\
Barclays & $1,586,881$ \\
Citigroup & $1,494,037$ \\
Deutsche Bank & $1,170,323$ \\
Goldman Sachs & 706,804 \\
HSBC Holdings & $1,501,970$ \\
JPMorgan Chase & $1,198,942$ \\
Radobank Group & 597,138 \\
Royal Bank of Canada & 398,051 \\
Westpac & 198,358 \\
WestLB Group & 312,532 \\
\hline Total assets & $10,204,006$ \\
\hline Total assets banking sector & $60,500,000$ \\
\% of total within sector & $17 \%$ \\
\hline
\end{tabular}

Box VII provides an example of a leader in integrating biodiversity in credit lending - Rabobank. This bank is using a CSR policy for all its credit-lending activities as of the $1^{\text {st }}$ of February 2007 where 3 out of 10 guiding principles touch upon biodiversity, which risk analysts and client relation managers are obliged to use.

Although most of these banks also have extensive programs in place that support various social and environmental initiatives, including biodiversity-related ones, this is regarded as philanthropy and is therefore left outside the scope of this assessment.

dd The Environment Index is a product of Business in the

Community (BiTC). It is a business-led, voluntary and self-assessed

corporate environmental benchmark. See http://www2.bitc.org.uk

ee This may also be due to an increasing phenomenon, namely

"survey fatigue".

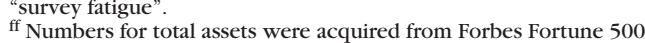

(as of December 2006) 


\begin{tabular}{|c|c|c|c|c|c|c|c|c|c|c|c|c|c|c|c|}
\hline \multirow[t]{2}{*}{ Name } & \multicolumn{3}{|c|}{ 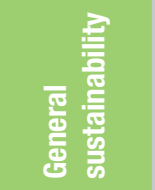 } & \multicolumn{10}{|c|}{ Sector guidelines } & \multirow[t]{2}{*}{$\begin{array}{l}\text { Implemented in company } \\
\text { operations }\end{array}$} & \multirow[t]{2}{*}{ Biodiversity relevance } \\
\hline & 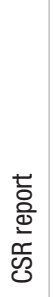 & 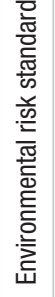 & 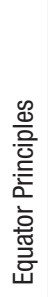 & 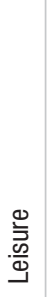 & 莺 & 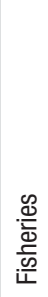 & $\begin{array}{l}\text { 일 } \\
\frac{\bar{z}}{\overline{3}} \\
\text { 产 }\end{array}$ & $\begin{array}{l}\mathscr{g} \\
ٌ \\
\infty \\
\bar{\sigma}\end{array}$ & केषे⿺ & 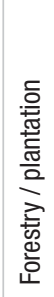 & 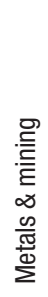 & 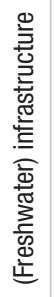 & $\begin{array}{l}\frac{\infty}{\mathbb{N}} \\
. \frac{0}{E} \\
\frac{0}{0}\end{array}$ & & \\
\hline ABN AMRO & $\checkmark$ & $\checkmark$ & $\checkmark$ & & & & & $\checkmark$ & & $\checkmark$ & $\checkmark$ & $\checkmark$ & & $\begin{array}{l}\text { Forestry } \\
\text { - All clients } \\
\text { Metals and Mining } \\
\text { - All clients } \\
\text { Dams } \\
\text { - Project finance \& } \\
\text { advisory } \\
\text { - Cross-border structured } \\
\text { finance } \\
\text { - Corporate lending and } \\
\text { financial support } \\
\text { Oil and Gas } \\
\text { - All clients }\end{array}$ & $\begin{array}{l}\text { Forestry } \\
\text { - No financing of projects or operations, } \\
\text { which will result in resource extraction } \\
\text { from, or the clearing of, either primary or } \\
\text { high conservation value forests; } \\
\text { - No financing of previously cleared forest } \\
\text { land before five years have passed } \\
\text { and only if no direct link to the original } \\
\text { deforestation can be demonstrated; } \\
\text { - No financing of companies that are } \\
\text { involved with illegal logging operations. } \\
\text { Metals and mining } \\
\text { - For projects designated as protected by } \\
\text { the World Heritage or IUCN IProtected Area } \\
\text { Categories I-IV, companies require an ESIA } \\
\text { and Biodiversity Action Plan to be done by } \\
\text { an independent third party; } \\
\text { - No finance of project engagements } \\
\text { located in World Heritage Sites; } \\
\text { - In principle, no consideration of } \\
\text { engagements where tailings are disposed } \\
\text { directly into a riverine environment. } \\
\text { Dams } \\
\text { - The policy is informed by the guidelines of } \\
\text { the International Hydropower Association } \\
\text { and World Commission on Dams, and } \\
\text { aims to be consistent with ABN AMRO's } \\
\text { commitment to the Equator Principles. } \\
\text { Oil and gas } \\
\text { - Use of a Client Diagnostic Tool (CDT), } \\
\text { where biodiversity is a factor that } \\
\text { enables the bank to screen a client on its } \\
\text { sustainability profiles; } \\
\text { Heritage Sites. }\end{array}$ \\
\hline Barclays & $\checkmark$ & $\checkmark$ & $\checkmark$ & & & & & & & & & & & & $\begin{array}{l}\text { While Barclays does not have external sector } \\
\text { guidelines, it does use } 32 \text { internal sector- } \\
\text { specific guidelines for their clients that } \\
\text { operate in sensitive industries and sectors } \\
\text { and additionally topic-specific screening } \\
\text { for certain projects. This information is } \\
\text { consequently made available to the account } \\
\text { manager. }\end{array}$ \\
\hline Citigroup & $\checkmark$ & $\checkmark$ & $\checkmark$ & & & & & & & $\checkmark$ & & & & $\begin{array}{l}\text { Forestry } \\
\text { - Project finance } \\
\text { - Asset finance } \\
\text { - Corporate finance }\end{array}$ & $\begin{array}{l}\text { Forestry } \\
\text { - No provision of loans to companies, which } \\
\text { the bank knows are in violation with local } \\
\text { or national laws regarding illegal logging; } \\
\text { - When an "operation significantly converts } \\
\text { or degrades a critical natural habitat", the } \\
\text { loan is precluded under Citigroup's ESRM } \\
\text { policy. }\end{array}$ \\
\hline
\end{tabular}




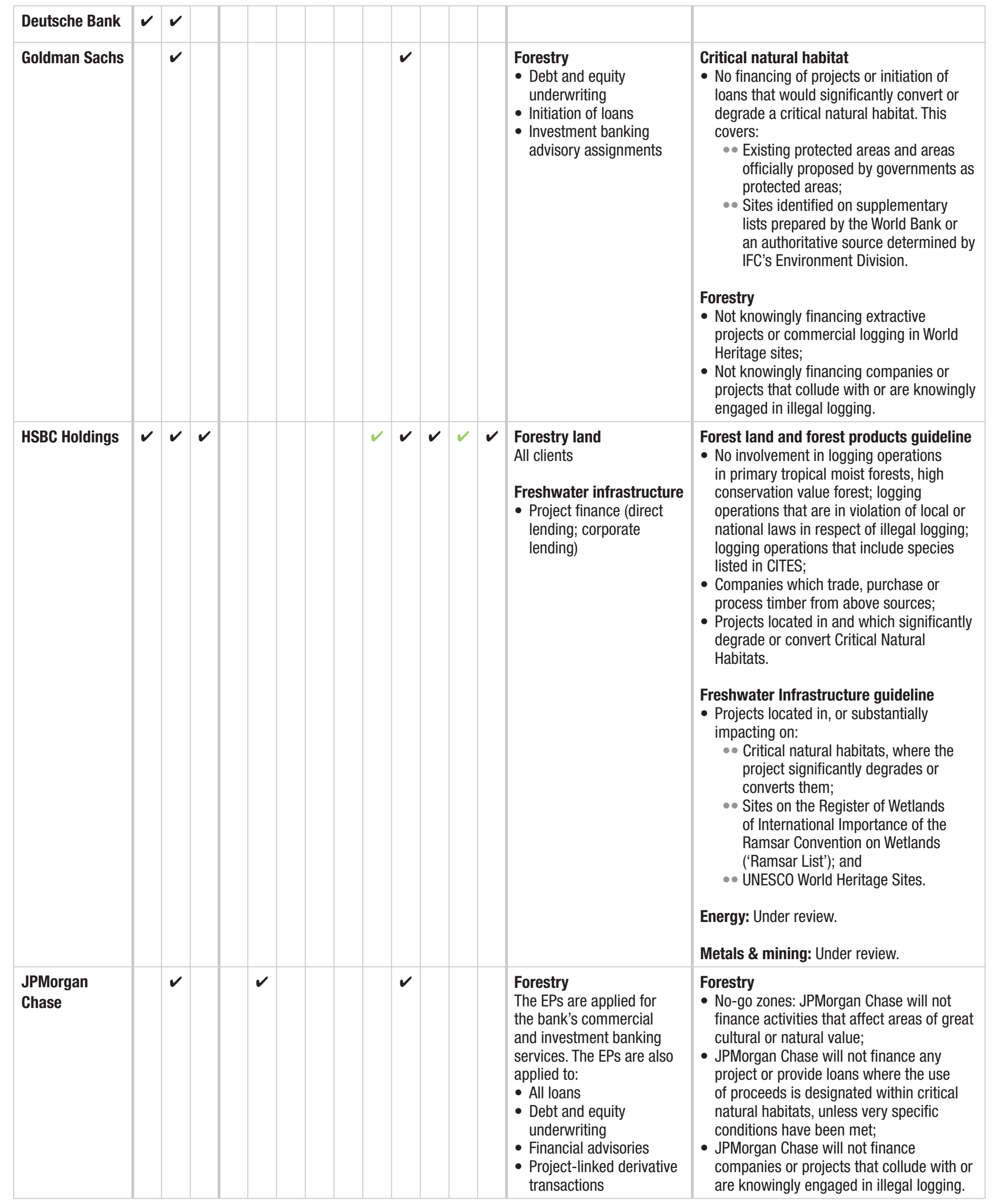




\begin{tabular}{|c|c|c|c|c|c|c|c|c|c|c|c|c|c|c|}
\hline Radobank & $v$ & $v$ & $v$ & $v$ & $v$ & $\checkmark$ & $v$ & $v$ & $v$ & $v$ & $v$ & $v$ & $\begin{array}{l}\text { Palm oil } \\
\text { The bank applies a code for } \\
\text { palm oil since } 2001 \text {. The } \\
\text { bank will apply a new code } \\
\text { worldwide to all clients that } \\
\text { source products containing } \\
\text { more than } 5 \% \text { total volume } \\
\text { of the product or when } \\
\text { more then } 25 \text { kilotons } \\
\text { absolute volume is used } \\
\text { per year. } \\
\text { Other policies } \\
\text { Applied to all clients, some } \\
\text { policies are still in an } \\
\text { approval process. }\end{array}$ & 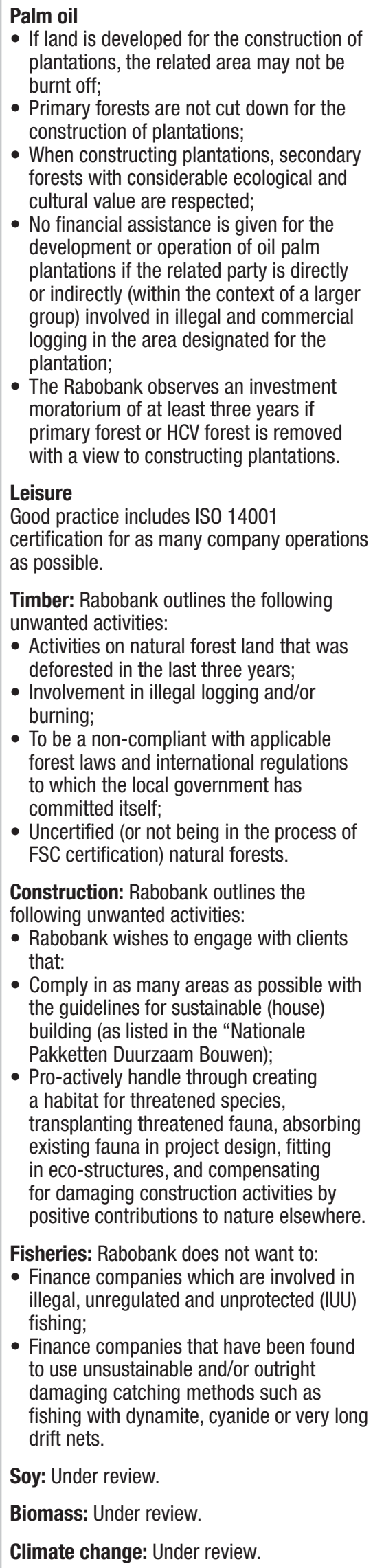 \\
\hline $\begin{array}{l}\text { Royal Bank of } \\
\text { Canada }\end{array}$ & $\checkmark$ & $v$ & $\checkmark$ & & & & & & & & & & & \\
\hline WestLB Group & $\checkmark$ & $\checkmark$ & $\checkmark$ & & & & & & & & & & $\begin{array}{l}\text { Several policies are under } \\
\text { review. }\end{array}$ & \\
\hline westpac & $\checkmark$ & $v$ & $\checkmark$ & & & & & & & & & & & \\
\hline
\end{tabular}

Fields that are marked " $\checkmark$ " are present within these institutions, while fields that are marked " $\checkmark$ " are in the process of development. Note: Almost all of the banks in the assessment can be regarded as universal banks, which means that they also offer asset management and insurance products. Some of the sector-guidelines that these banks have developed may also apply to asset management. 

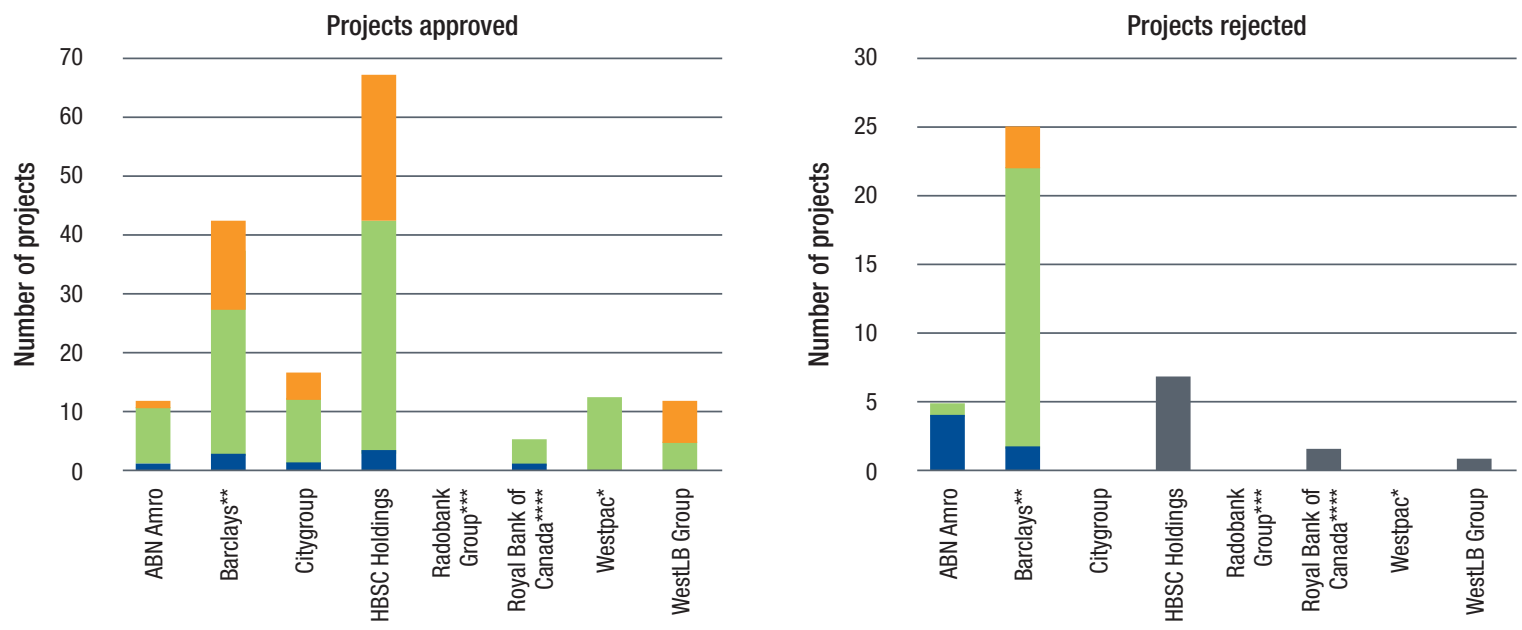

Category C: projects with little or no environmenta impact.

Category B: projects whose impacts on human populations or environmentally important areas are less adverse.

Category A: projects with significant adverse impacts which may affect an area broader than the project site.

The company did not provide a breakdown in categories.

${ }^{*}$ Although Westpac rejected a number of projects, this was not done so because of environmental concerns

${ }^{* *}$ This includes approved and pending projects by Barclays

${ }^{\star \star \star}$ No detailed information about how the equator principles have been implemented was available from the Rabobank Group.

${ }^{\star \star \star \star}$ RBC has rejected 2 EP projects over the course of 2004-2006 (not for 2005 specifically)

Note:

1) The scale of the $y$-axis is different for both graphs.

2) Goldman Sachs and JPMorgan Chase have not adopted the Equator Principles, but have drafted forestry and climate guidelines that follow the principles to a certain extent. Deutsche Bank has not adopted the Equator Principles

3) HSBC, RBC and WestLB have not disclosed the category of the rejected projects (grey bars)

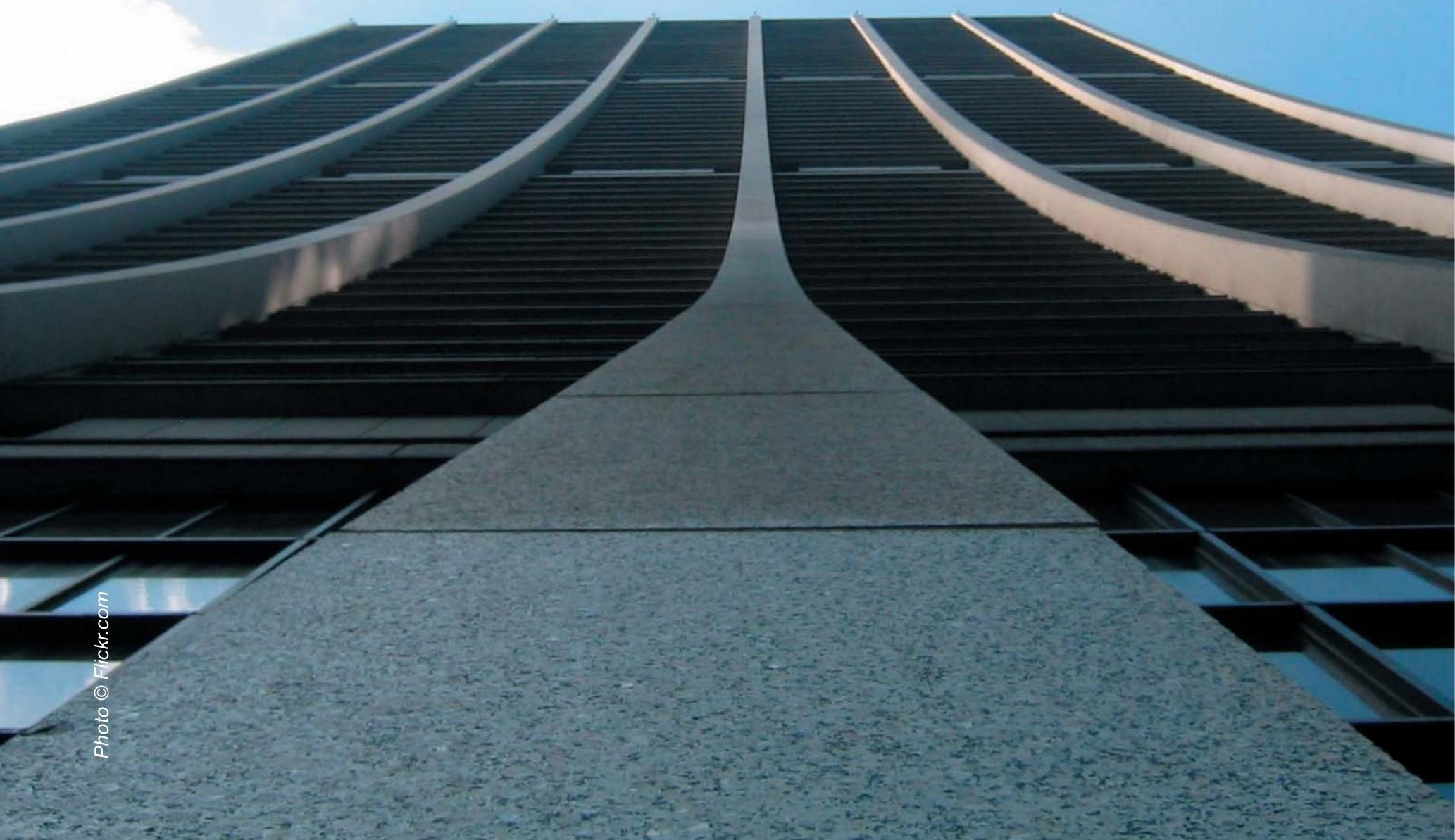




\section{Box VII.Rabobank's CSR tool: Integrating ESG (including biodiversity) deep into the banks's operations}

As of the $1^{\text {st }}$ of February 2007 Rabobank is using a Corporate Social Responsibility tool throughout all its credit-lending activities (!) regardless of the credit sum (with regard to SMEs, there is a $€ 1$ million minimum).

The essence of the tool is that Rabobank engages with its clients in a dialogue on a number of social and ecological issues that are important within the sector, or within the country in which the company is active. For this purpose the bank applies ten general issues that it uses as a frame of reference for its sector-specific policy documents, the review of its clients and the assessment of credit applications. Three of these touch upon biodiversity (environmental pollution, depletion of natural resources and cruelty against animals).

- Corruption

- Bad labour conditions

- Abuse of employees or benefit from it (direct or indirect)

- Serious child labour

- Environmental pollution

- Depletion of natural resources

- Cruelty against animals

- Defile the rights of indigenous communities

- Discrimination

- Products or services with health or safety consequences for consumers

To support its client relation managers and credit analysts the bank has developed sector-guidelines for the 1) leisure sector; 2) construction sector; 3) fisheries sector (Europe); 4) palm oil; 5) chemicals; and 6) timber sector. Furthermore the bank is in the process of developing guidelines for the soy sector and for biomass and climate change. The most important features of Rabobank's engagement strategy is that these are 1) issue-oriented (e.g., on child labour, environmental pollution); 2) use simple language to make it comprehensible to the client relation managers that are dealing with clients directly; and 3) specify unwanted practices (e.g., dynamite fishing) and good practices (e.g., nationally and internationally accepted industry standards, conventions and codes of conducts) in order not to appear biased towards their clients. Another very important feature of Rabobank's engagement strategy is that it is compulsory for the client relation managers and credit analysts to use the tool for every credit application. This is to avoid informal use of the tool.

The rationale for Rabobank to use such a tool or engagement strategy is that it believes that certain extra-financial issues can become a risk or an opportunity for its clients and therefore for the Rabobank Group. Firstly the bank believes that failing to account for social and environmental issues by its clients can undermine the continuity and the competitive position of these clients, thereby leading to increased default risk for Rabobank. Secondly the bank believes that identifying commercial opportunities connected to social and environmental issues, at an early stage, can lead to the development of new innovative products and services.

Source: Rabobank Group Corporate Social Responsibility Report 2006. Rabobank: Utrecht

\section{Box VIII. The Equator Principles (EPs), a trigger towards integrating sustainability into project finance and beyond?}

Influenced by the campaigning of the NGOs Rainforest Action Network and Friends of the Earth, and developed by the IFC in 2003 in consultation with a number of major banks (such as Barclays, HSBC and ABN AMRO), subsequently redrafted in July 2006 in accordance with IFC Safeguard Policy Review, the Equator Principles represent the first global effort to streamline project finance towards a more sustainable path. The principles are applied to project finance projects with a capital cost of more than US\$10 million.

The EPs consist of 10 principles which serve as guidelines for banks (more recently also other types of financial institutions are adopting the principles, such as export credit agencies) which voluntarily commit themselves to screening project-finance applications on a number of social, human-rights and environmental issues (including biodiversity), based on A, B and C categories (Figure 11).

The guidelines are naturally set more strictly for category A and category B projects (when carried out in non-high income countries, as determined by the World Bank methodology). In addition, the following exclusion criteria are used. If the project meets any of these criteria, it is rejected straight away:

- Conversion or degradation of a critical natural habitat;

- Logging operations in primary tropical moist forest.

The most serious critique of NGOs of the newly launched EPII, however, is the lack of consistent and rigorous implementation of the EPs. In addition, they feel that the scale of the impact, not the nature of the transaction, should be the common denominator when applying the EPs.

It can be recognized though that the principles have triggered a greater effort by Fls towards sustainable finance as the new set of principles also includes project finance advisory services. In addition, recently a growing number of financial institutions are expanding the EPs to other financial services such as corporate loans, debt security underwriting and equity underwriting for clients in certain sectors (Table 6.). This can clearly be seen as a sign that financial institutions are making serious efforts towards financing more sustainable businesses and projects.

However, the real contribution of the principles will emerge in a few years when it becomes clear which Fls have acted according the principles and which ones have used it as a public relations stunt. 
It can be concluded from Table 6 and Figure 11 that on a general level environmental issues are starting to be recognized by these banks as nearly all have some sort of environmental policy in place as well as producing annual sustainability reports. When focusing specifically on biodiversity related issues, the following can be concluded:

- HSBC and Barclays finance a considerable number of projects that fall under the EP umbrella. Most projects concern so-called $\mathrm{B}$ and $\mathrm{C}$ category projects, which can be regarded as medium and low risk projects according to EP categories (see also Box VIII)

- It is remarkable that ABNAMRO and Barclays have rejected about $1 / 3$ of project finance applications (although these banks have not disclosed for what reasons they have rejected the projects).

- In addition to the EPs, at least six of the 11 banks have drafted sector-specific guidelines that go beyond the EPs. The sectorspecific guidelines, though often not referring to biodiversity specifically, catch the essence of biodiversity through concepts such as critical natural habitat, primary tropical moist forest, riverine environment, high conservation value forest and World Heritage sites. These guidelines further integrate environmental and biodiversity issues into the credit lending and some of the investment products of these banks.

- There is, however, a considerable difference in 1) how far banks have proceeded to draft sector guidelines, as well as 2) to which types of financial products these guidelines and policies apply. Rabobank appears to have gone furthest by applying their new CSR tool, in effect as of 1 February 2007, to all their credit-lending activities (see Box VII). This also includes a range of sector guidelines. ABN AMRO and HSBC also appear to have progressed to some extent by having developed several sector guidelines. Furthermore it should be acknowledged that Goldman Sachs has endorsed the Biodiversity Benchmark, developed by Fauna \& Flora International and Insight Investment, ${ }^{10}$ to guide its investment operations. ${ }^{66}$
- Though these banks have clearly recognized environmental and biodiversity issues as a business issue to some extent, it would be dangerous to extrapolate this to the entire sector as reports by Oxera ${ }^{63}$ and $\mathrm{F} \& \mathrm{C}$ Asset Management ${ }^{34}$ concluded limited awareness and activity by the banking sector towards integrating biodiversity issues into their business operations.

\subsection{Asset management}

This category of the financial sector refers to the management of pools of capital on behalf of third parties. Asset management (AM) involves investing in the following types of asset classes: equities, bonds, cash, property, international equities \& bonds, alternative assets (e.g., private equity, venture capital, mutual $\&$ hedge funds). It also encompasses elements of investment banking.

\subsubsection{Environmental risk assessment by asset managers} Before proceeding with the actual environmental risk screening it is important to know how asset management works. The basic idea behind asset management is that a manager of an AM firm pulls together a number of companies in a fund, on behalf of its investors, often with a particular focus on a 1) sector; 2) commodity; 3) region, to buy-in stakes in the company. In the case of public companies, the fund will buy stocks of a company (e.g., mutual and hedge funds) and in cases of non-listed companies the fund will buy into a private company (i.e. private equity funds). Fund managers are usually seeking the highest returns on their investments for their investors, which may either be private investors or institutional ones (e.g., pension funds).

Socially Responsible Investing (SRI) has emerged over the last two decades within the AM world. SRI focuses on investments in sectors or companies that demonstrate progression towards sustainable development. SRI essentially involves the following strategies $^{67}$ :

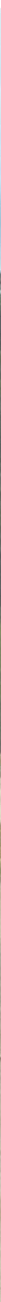


1. Positive selection (screening) of corporations: The selection of stocks of companies that perform best against a defined set of sustainability criteria (best of class approach);

2. Engagement with management: Influencing corporate policy through associated rights of being an investor;

3. Voting power at Annual General Meetings (proxy voting);

4. Negative screening or exclusion. For example the exclusion of the weapons or tobacco industry.

While there is no single approach to SRI and although it remains difficult to define, there is a general trend in terms of absolute growth in SRI throughout Europe and the USA.The European Social Investment Forum (Eurosif), has made a division between "core SRI"gg and "broad SRI" and came to figures for core SRI of $€ 105$ billion and broad SRI $€ 1.03$ trillion (December $31^{\text {st }} 2005$, see Figure 12). Within the United States, total SRI assets rose from US\$639 billion in 1995 to US\$2.29 trillion in $2005^{68}$ (Table 7).

There are also many rating agencies and international benchmarks that track the environmental performance of companies (see Annex II for an overview of 19 rating and benchmarking tools ${ }^{\mathrm{i}}$ ).

Many fundamental (i.e. conventional) investors consider environmental issues to be a topic simply for SRI markets, as SRI markets are associated with people who are putting environmental and social issues at the head of investment decision making (instead of financial ones) and would therefore be satisfied with lower returns.

It should be understood, however, that environmental issues can definitely have implications for fundamental or conventional investors as well. When environmental risks are not properly factored-in to the screening of companies for a certain portfolio, $\mathrm{AM}$ and investors neglect the fact that the respective companies may be at risk from regulatory, reputational and litigation risks. This might in turn have implications for the share or stock price of the company and thereby on the performance of the fund (and the eventual return for the investors).A report by Goldman Sachs that specifically focused on climate change, states that if companies do not act proactively on this issue it might become a liability, both for them as well as for their investors ${ }^{69}$.

Other than understanding that environmental issues are not solely related to SRI is the perception that SRI represents a niche market. Subsequently, there are doubts whether it can become more widely accepted to support a dedicated effort in this area. Notwithstanding the growth in SRI assets, prior investment results in this area have been mixed. ${ }^{69}$ Since SRI investing does not always deliver suitable investment returns, this may not be a sustainable option for several institutional investors and, therefore, there may not be high ongoing demand for SRI investment vehicles. However, recognizing that current SRI assets in the USA account for $9.4 \%$ of total assets under management ${ }^{68}$ this perception is somewhat outdated as well. It can therefore be argued that SRI is moving away from the perception that it represents "a niche market" within conventional AM.

In addition, recent academic work and developments in financial markets point to the fact that SRI can lead to superior portfolio performance compared to similar fundamental funds

Derwall et al. $(2005)^{70}$ show evidence that large-

cap companies labelled "most eco-efficient" sizably outperformed a less eco-efficient portfolio over the 1995-2003 period by six percentage points, under different transaction cost scenarios. The difference could not be explained by differences in market sensitivity, investment style or industry bias.

Even more recently GLG partners, which is a US\$17 billion London hedge fund manager, announced to investors on 16 February 2007 that it planned to start an Environmental Fund filtering the greenest companies from its US $\$ 1.5$ billion European Equity Strategy. GLG is aiming to pick stocks of companies that have a 30\% "lighter" impact on the environment compared to average companies. GLG announced that backtesting proved

Figure 12. SRI strategies as applied in Europe December $31^{\text {st }}, 2005$; Billion $€)^{67, \text { hh }}$

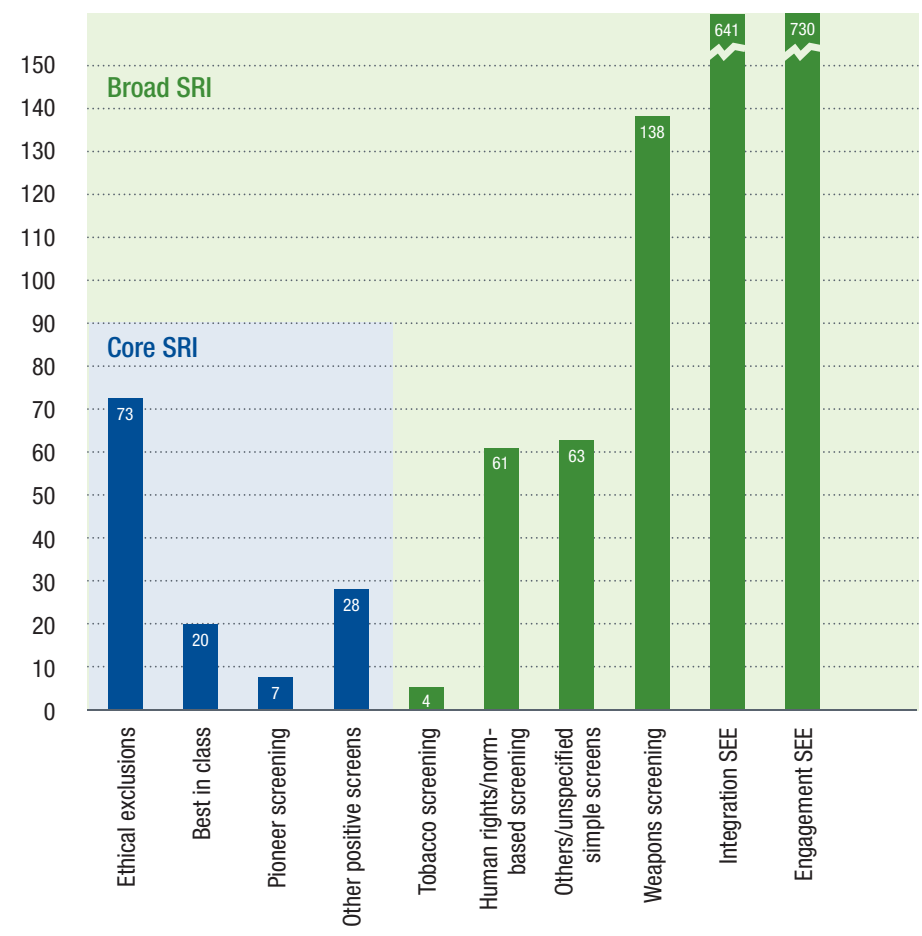

Table 7. Trends in SRI in the USA (1995-2005) ${ }^{68}$

\begin{tabular}{|l|r|r|r|r|r|r|}
\hline (in billions) & 1995 & 1997 & 1999 & 2001 & 2003 & \multicolumn{1}{|c|}{2005} \\
\hline Social Screeing & $\$ 162$ & $\$ 529$ & $\$ 1,497$ & $\$ 2,010$ & $\$ 2,143$ & $\$ 1,685$ \\
\hline Shareholder Advocacy & $\$ 473$ & $\$ 736$ & $\$ 922$ & $\$ 897$ & $\$ 448$ & $\$ 703$ \\
\hline Screening and Shareholder & $\mathbf{N} / \mathbf{A}$ & $(\mathbf{\$ 8 4})$ & $(\mathbf{\$ 2 6 5 )}$ & $\mathbf{( \$ 5 9 2 )}$ & $\mathbf{( \$ 4 4 1 )}$ & $\mathbf{( \$ 1 1 7 )}$ \\
\hline Community Investing & $\$ 4$ & $\mathbf{\$ 4}$ & $\mathbf{\$ 5}$ & $\mathbf{\$ 8}$ & $\mathbf{\$ 1 4}$ & $\mathbf{\$ 2 0}$ \\
\hline Total & $\mathbf{\$ 6 3 9}$ & $\mathbf{\$ 1 , 1 8 5}$ & $\mathbf{\$ 2 , 1 5 9}$ & $\mathbf{\$ 2 , 3 2 3}$ & $\mathbf{\$ 2 , 1 6 4}$ & $\mathbf{\$ 2 , 2 9 0}$ \\
\hline
\end{tabular}

Source: Social Investment Forum Foundation

${ }^{1}$ Social Screening includes mutual funds and separate accounts. Since 2003, SRI mutal fund assets have increased while separate account assets have declined as single issue screening has waned and shareholder advocacy increased on the part of institutional investors.

${ }^{2}$ Assets involved in Screening and Shareholder Advocacy are subtracted to avoid double counting. Tracking Screening and Shareholder only began in 1997, so there is no dataum for 1995

gg Core SRI: Ethical exclusions, positive screening (including Best-inclass, Pioneer screening); Broad SRI: Core SRI plus simple exclusions, including norms-based screening, plus engagement and integration. hh Please note that the total of individual strategies will be superior to total SRI given the areas of overlap.

ii As far is this overview is concerned it can be concluded that at present only the Environment Index (from Business in the Community) is also factoring in biodiversity issues into their rating system. 
the viability of their environmental approach, which assumed a long-only strategy that would not sell shares short to profit from price falls, produced annual returns of $27.6 \%$ after fees (compared to a main strategy (26.4\%) from the European Equity fund). ${ }^{71}$ Another hedge fund that runs environmental screens is Green Cay Asset Management. The number of mutual funds that screen for environmental (and social) aspects, however, far exceeds the number of hedge funds. Currently in Europe alone there are about 300 mutual funds that screen on sustainability aspects. ${ }^{8}$

These developments have not only arisen because of concerns by private investors, institutional investors are also increasingly turning towards including environmental screening as part of the process. Two noteworthy developments should be mentioned. First, Investor Network on Climate Risk (INCR), a coalition of investors, representing US $\$ 2.7$ billion in assets, promotes investor and corporate engagement and understanding of the range of risks posed by climate change ${ }^{69}$. The second is the Enhanced Analytics Initiative (EAI) $)^{\mathrm{ji}}$, which is a collaboration of mainstream asset owners and asset managers who believe that extra-financial issues (EFI), which are fundamentals that have the potential to impact a company's financial performance or reputation in a material way, but are generally not part of traditional fundamental analysis such as climate change or branding, need to be incorporated in investment research. It is believed that incorporating these hard-to-monetize and quantifying EFIs will ultimately lead to more informed investment decisions and added value in the long term. EAI members, who represent assets under management of $€ 1.3$ trillion, have allocated a minimum of $5 \%$ of their respective brokerage commission budgets for the first half-year of 2005 to sell-side research houses who analyze EFIs and intangibles. Although biodiversity was not particularly mentioned, this is a sign that large institutional investors are also starting to realize that critical issues, such as the environment, have remained absent in traditional fundamental analysis for too long.

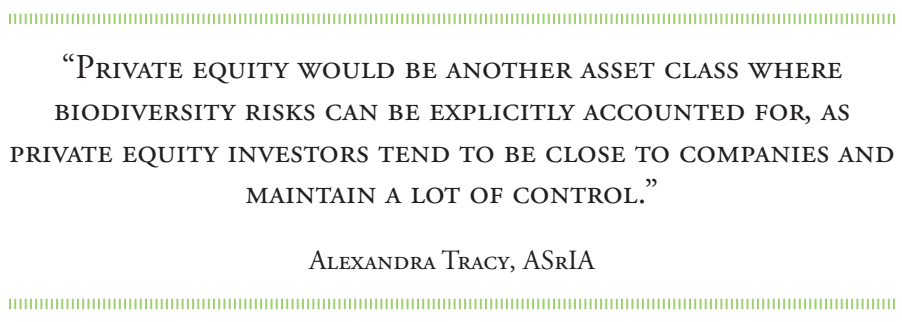

ij The EAI currently has 14 full members and includes ABP

Investments, which is the second largest pension fund in the world.

See www.enhancedanalytics.com

\subsubsection{How can asset managers be exposed to biodiversity risks?}

AM are less directly exposed to BBRs than commercial banks, since they are less directly engaged with companies. In addition, AM often have large numbers of companies in a portfolio. However, while individual underperformance of a particular company can easily be overcome at present, the business relevance of biodiversity is further set to increase. It is therefore important for AM, institutional \& private investors to understand what factors are contributing to a greater exposure of BBRs to their services. These include (but may not be limited to):

- Investments in companies with high impacts on ecosystems and/or ecosystem dependent companies. AM face risks when holding large shares in companies that are dependent on healthy ecosystems (i.e. agriculture, fisheries and tourism among others) or companies that have high impacts on or operate in sensitive ecosystems. This is even more so when portfolios are fully focused on these types of companies or when portfolios are relatively small.

- Tighter regulations. AM are indirectly affected when they hold shares of companies that are subject to tighter regulations (e.g., companies with high impacts on ecosystems or with activities in high conservation value areas). Directly, AM can be affected when they themselves become subject to tighter regulations. Being ill prepared can lead to cost increases. Private equity funds, for example, are protected from the scrutiny received by publicly traded securities and operate without the oversight and reporting requirements of public markets,${ }^{72}$ making them at present less susceptible to regulatory constraints than mutual and hedge funds.

- Timeline of the fund. Generally speaking, it can be argued that funds that operate over one or several years are more prone to biodiversity risks than funds that typically turnover within months. The long-term horizon in which private equity (PE) funds operate, for example, make them potentially more prone to biodiversity risks than hedge funds based on this particular factor.

- Scrutiny from pressure groups. For example, Shell came under scrutiny during the Brent Spar incident. Certain NGOs scrutinize companies hoping to catch the attention of the media and thereby changing the public perception and reputation of companies. Examples include the Greenpeace activism involving the dumping of the Brent Spar in the North Sea by Shell in the mid 90s and the activities by the Rainforest Action Network towards Citigroup. Contrary to commercial bank lending activities, investors and AM are often much less affected by these activities and therefore less susceptible to these types of risk.

Table 8. How different types of investment funds may be prone to biodiversity risks

\begin{tabular}{|l|l|l|}
\hline Type of fund & Characteristics & Type of risk \\
\hline Mutual funds & $\begin{array}{l}\text { Mutual funds, which typically turn over within a year, are perhaps the types of funds most } \\
\text { exposed to BBRs (and other environmental risks). Currently, there are about } 300 \text { mutual } \\
\text { funds available that are managed according to sustainability and social responsibility. }\end{array}$ & $\begin{array}{l}{ }^{73} \\
\bullet \text { Underperformance due to neglecting BBRs }\end{array}$ \\
\hline Hedge funds & $\begin{array}{l}\text { Their nature of pulling in and out of companies within days or months, make hedge funds } \\
\text { extremely flexible or volatile and therefore appear to be less exposed to biodiversity } \\
\text { (and other environmental) risks, except of course when a fund underperforms due to } \\
\text { environmental reasons. }\end{array}$ & $\begin{array}{l}\bullet \text { Underperformance due to neglecting BBRs } \\
\bullet \text { Potential regulatory constraints }\end{array}$ \\
\hline Private equity & $\begin{array}{l}\text { These types of funds often operate on long-term strategies (>3 years). These types of } \\
\text { funds operate without the oversights and reporting requirements of public markets. }\end{array}$ & $\bullet$ Underperformance due to neglecting BBRs \\
\hline
\end{tabular}


- Climate change. Climate change is a driver of ecosystem degradation and biodiversity loss. Not understanding the interlinkages between the two phenomena may pose risks to both companies and investors.

- Reputational risks. By having companies in a portfolio that are unethical or that have bad environmental records, asset managers face potential biodiversity risks as well.

Table 8 provides some preliminary insights on how these biodiversity risks can impact specific types of AM funds: private equity, mutual funds and hedge funds. In principle, all types of funds are potentially exposed to BBRs when it somehow leads to underperformance of a fund. In addition, fund managers can for example become exposed to increased regulation from policy makers.

\section{4 (Re)insurance}

Insurance can be regarded as a promise of compensation for a specific potential future loss, in exchange for a periodic payment and includes both pension and life insurance services. The types of services that are offered in this type of category are provided directly or through independent financial advisors to the general public and employees of companies. It also covers the insurance of products or services for businesses and reinsurance services. Reinsurance involves the risks borne by insurance companies being taken on by another company or companies. In essence, reinsurers insure insurers.

\subsubsection{Environmental risk assessment by (re)insurers}

Arguably the financial segments that are most interested in environmental (and biodiversity) risks and how these emerge and transfer over time are the insurance and reinsurance sectors. They face environmental risks when there is an improper calculation of the possibility of an environmental harmful occurrence and the economic costs as a result of the damage, in relation to the price an insured party is paying to cover for these risks.

Environmental damage may manifest itself in many ways. Traditional types of environmental damage (re)insurance firms cover include: ${ }^{74}$

- Property loss on the basis of sudden and accidental pollution. This can happen when an accident occurs that causes damage to the company (first-party loss).

- Liability loss on the basis of sudden and accidental pollution. This may happen when breakdown of a factory leads to (health) damage to people, property, and ecosystems in the vicinity (third-party loss). This for example happened after a series of dam breakdowns in Spain and Romania between 1998 and 2000. The Baia Mare dam breakdown in Romania, for example, on the $30^{\text {th }}$ of January 2000 after a sequence of unfavourable weather conditions led to serious damage to fish stocks and bird populations, and a decline in tourism for the foreseeable future. $^{75}$

- Liability loss caused by gradual pollution. Discharge by factories, agribusiness or other industrial activities may lead to build-up of pollutants in the environment and in ecosystems, causing damage to fish stocks, forests, etc.

- Product liability loss. This may happen when, for instance, the use of pesticides or herbicides leads to ecological damage.

- Property/liability loss due to an operational breakdown. This may happen when hazardous pollutants pollute the soil and groundwater on the company's premises and in the surrounding area.The damage is often not discovered until much later (historical pollution).
Recently, however, the insurance sector has had to grow accustomed to new types of environmental risks. The most noteworthy of all are the increases in extreme weather events as a result of climate change. Increases in number and especially severity of hurricanes across the Atlantic coast of the US are leading to high economic costs. While hurricane Andrew in $1992^{76}$ caused the biggest loss in the history of natural catastrophes, a series of hurricanes in 2005, of which hurricane Katrina was the most expensive, have caused billions of dollars of damage again. As a result prices have risen by up to $300-400 \%$ for oil companies in the Gulf of Mexico seeking insurance and insurers seeking reinsurance to protect against offshore losses, including damage from hurricanes. ${ }^{77}$ In 2003 , climate change took centre stage as countries across Europe experienced their hottest summer on record. Economic losses from crop failure and forest fires alone accounted for US\$14 billion. During 2002, major floods across Europe caused total damage of almost US\$ 16 billion and insured losses of just over US $\$ 3$ billion. ${ }^{78}$ A study by Swiss scientists ${ }^{79}$ combined SwissRe's climate change loss model with current (IPCC) climate models to assess how trends in economic loss due to winter storms in Europe will likely emerge. They concluded that claims are forecast to increase by $16-68 \%$ over the period 1975 to 2085 (in constant currency).

Environmental risk assessment in the (re)insurance sector means that environmental events (such as extreme weather events) have to be systematically integrated into risk assessment and risk management processes. While climate change has risen up the agenda of the (re)insurance business, biodiversity is a different story.

\subsubsection{How can the (re)insurance sector be exposed to biodiversity risks?}

Biodiversity issues mainly come into play in the (re)insurance business when there are changes in liability. Specifically for biodiversity, this can happen when operators have caused damage to ecosystems in terms of sudden events or gradual pollution and they are being held liable for that. Liability is driven by changes in regulation and regulation in turn is driven by forces in society.

So far, liability from environmental damage has only extended to property damage or personal injury. This is because biodiversity comprises a number of characteristics that make it difficult to insure.Table 9 provides a number of conditions that need to be met in order for a commodity or activity to be insurable and to what extent this accounts for biodiversity. ${ }^{80}$

However, declining global biological resources and expectations that this will continue may extend environmental liabilities to fauna and flora issues as well. ${ }^{81} \mathrm{~A}$ noteworthy development is taking place in the EU at present, as environmental liability will be extended to not only include personal injury and property damage, but a stricter regime that makes operators of sites liable for damage to the environment including flora and fauna.$^{82}$ This new directive will come into force as of 30 April 2007 throughout the whole EU. ${ }^{83}$ As traditional liability and property policies do not adequately cover environmental risks, the (re)insurance sector will need to adjust to this new liability directive.

In general, the (re)insurance sector will need to respond to changes in ecosystems and subsequent stricter national (liability) regulations. Also extreme weather conditions and the effects of climate change on ecosystems are elements the (re)insurance sector will need to respond to in order not to face excessive risks. 


\begin{tabular}{|c|c|c|c|}
\hline Conditions for insurability & $\begin{array}{l}\text { Are these conditions met for } \\
\text { biodiversity? }\end{array}$ & How can the issue be addressed? & What role for government action? \\
\hline $\begin{array}{l}\text { 1. Risk pooling across many insured } \\
\text { persons/companies }\end{array}$ & $\begin{array}{l}\text { As long as biodiversity is regarded } \\
\text { a public good it is likely to be } \\
\text { insurable. }\end{array}$ & Possible use of reinsurance. & $\begin{array}{l}\text { Government could act as insurer, } \\
\text { with the taxpayer bearing the costs } \\
\text { of error if funds do not pay out. }\end{array}$ \\
\hline 2. Clear, definable loss & $\begin{array}{l}\text { Demonstrating quantified damage } \\
\text { from biodiversity loss is extremely } \\
\text { complex. }\end{array}$ & $\begin{array}{l}\text { Economic valuation techniques can } \\
\text { minimize uncertainty. }\end{array}$ & $\begin{array}{l}\text { Potential for the government to act } \\
\text { as insurer. }\end{array}$ \\
\hline $\begin{array}{l}\text { 3. Availability of prior information } \\
\text { about probabilities and size of } \\
\text { event }\end{array}$ & $\begin{array}{l}\text { Rates of biodiversity loss are } \\
\text { scientifically disputed, as are causal } \\
\text { mechanisms on which to base } \\
\text { probabilities. }\end{array}$ & $\begin{array}{l}\text { Possible use of reinsurance. Risk } \\
\text { and environmental audit can reduce } \\
\text { uncertainty about likelihood and } \\
\text { scale of event. }\end{array}$ & $\begin{array}{l}\text { Government could act as insurer as } \\
\text { above. }\end{array}$ \\
\hline 4. No moral hazard & $\begin{array}{l}\text { No, but could potentially be } \\
\text { addressed. }\end{array}$ & $\begin{array}{l}\text { Address via acquisition of } \\
\text { information, deductibles, co- } \\
\text { insurance and upper limits. }\end{array}$ & $\begin{array}{l}\text { Government information campaigns } \\
\text { could change behaviour. }\end{array}$ \\
\hline 5. No adverse selection & $\begin{array}{l}\text { No, but could potentially be } \\
\text { addressed. }\end{array}$ & $\begin{array}{l}\text { Information acquisition to impose } \\
\text { differentiated premiums by risk } \\
\text { group. Assumes knowledge of causal } \\
\text { factors in biodiversity loss and } \\
\text { ascription of responsibility for loss. }\end{array}$ & $\begin{array}{l}\text { Government information source may } \\
\text { help insurers. }\end{array}$ \\
\hline 6. Must be enforceable & $\begin{array}{l}\text { It remains difficult to enforce } \\
\text { international biodiversity agreements } \\
\text { (such as the CBD). }\end{array}$ & $\begin{array}{l}\text { Laws may impose penalties for non- } \\
\text { compliance. }\end{array}$ & $\begin{array}{l}\text { Legal liability rules to be established } \\
\text { by governments. }\end{array}$ \\
\hline
\end{tabular}




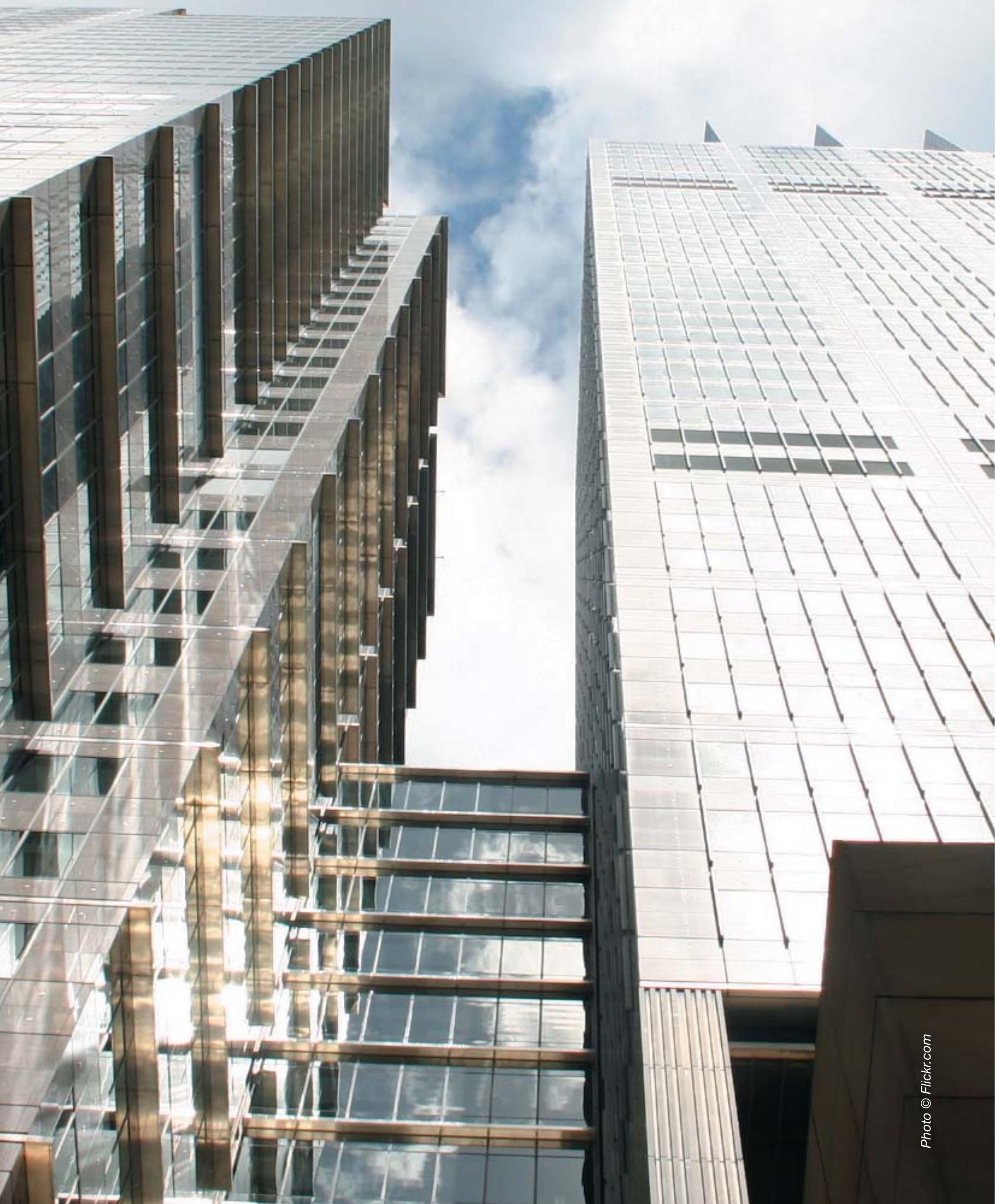




\section{A general procedure to account for biodiversity risks}

Following chapter 3 and 4, which focused specifically on how biodiversity risks can impact on FIs, chapter 5 provides a general procedure for those FIs that understand the potential materiality of the issue and that want to identify how biodiversity can be integrated into their business structures. Section 5.1 outlines first of all the abilities by FIs to retain BBRs. This provides the bases for the procedure, which is highlighted in section 5.2, how biodiversity can be integrated in (existing) risk management procedures (RMP). Section 5.3 outlines a number of factors that contribute to a successful integration of biodiversity into risk management procedures

\subsection{Financial institution's ability to mitigate biodiversity business risks}

Before focusing on a procedure to account for biodiversity in a company's RMP, it is foremost important to realize what sorts of possibilities different types of FIs have in retaining biodiversity risks.

\subsubsection{The ability of commercial banks to mitigate biodiversity business risks}

Commercial banks have the ability to respond to BBRs by means of thorough due diligence work and/or environmental impact assessments (EIA) that include biodiversity components. Also, constructive dialogues with clients, engagement, are an important means to reduce exposure to BBRs, for example by pointing clients to sector-specific best management practices (BMPs)

However, even when banks have identified biodiversity as being material in their credit activities, there are a number of factors that determine whether banks are capable of addressing and mitigating these BBRs:

- Use of the loan. It is easier for banks to assess potential risks tied to a particular loan when the bank is aware for what purposes/activities a client is using it.This is often the case with structured finance. Corporate finance, however, is a different story. Only when the use of the proceeds is known to have an effect on ecosystems, are banks fully able to react proactively on it (e.g., in the case when corporations use large parts of loans for one particular activity). However, in practice banks can be assumed to be aware which companies have sound environmental and social structures embedded in their business operations and which ones have not.This makes it possible for banks to pay extra attention to those clients that are likely facing biodiversity risks.

- Client-bank relation. A bank has much more influence on its client's corporate policies if there is a good relationship between the parties and the bank is the so-called "house-bank". In the case where a (small) bank does business with a large multinational firm and that firm has connections with other banks as well, it is much more difficult to use its influence to change a client's corporate strategy or risk management process.

- Position in the chain. A bank will likely impose stricter standards on clients that are at the start of the supply chain (which naturally have the highest impacts on ecosystems) than clients that are for example intermediate traders.

- Type of product. For certain products, with complicated supply chains and stakeholders, it is more difficult to account for biodiversity risks than for products that are straightforward and easy to assess.

\subsubsection{The ability of asset managers to mitigate biodiversity} business risks

Where commercial banks can integrate biodiversity performance tools/indicators into their risk management procedures, asset managers have two different mechanisms in place to mitigate biodiversity risks:

1) Voting during shareholder meetings. AM have the ability to ask questions and to use (proxy) voting as a means to force the management of a company in which it has a stake to change its policies on biodiversity.

2) Negative and positive screening. AM can screen-out sectors, companies or specific issues (e.g., child labour) for all or certain portfolios.Although it is becoming more common to screen-out certain unethical sectors, such as the weapons sector, it can be difficult to screen-out on issues such as these (biodiversity, child labour, human rights). Rather, it is better to engage with companies in a constructive dialogue to solve any unethical or environmental issues.

\subsubsection{The ability of (re)insurance firms to mitigate biodiversity business risks.}

As biodiversity possesses a number of characteristics that make it difficult to develop insurance products for, should the insurance and reinsurance sector start to develop services and products tailored to biodiversity, the most likely strategy for (re)insurers would be to start offering products with higher-than-normal insurance premiums.

\subsection{A general procedure to account for biodiversity in risk management procedures}

The procedure, which provides a systematic overview of existing tools, is one possible way for FIs to see how impacts on ecosystems can be identified, and what tools are available to mitigate any BBRs they might be exposed to, as well as what procedures banks, asset managers and insurers have in place to mitigate BBRs (e.g., due diligence, EIA, engagement, etc). The steps are highlighted below (see Figure 13).

Identifying important biodiversity areas. The first step concerns identifying if there are any biodiversity-adverse impacts to be expected from a certain project or investment. There are a number of tools available.

If so, a FI should look at the possibilities there are to reduce the impact on ecosystems thereby mitigating any business risks that can emerge.

Tools that factor-in integrating biodiversity into RMP. In order for FIs to mitigate biodiversity risks they need to be fully aware of the tools they can use in their risk management processes. Depending on the type of transaction and the type of financial service, FIs could pick the appropriate ones. These can be integrated into existing risk management procedures (RMP).

Conventions and sector-specific BMPs. In addition to available tools, client relation managers, credit analysts, fund managers and anybody else who will be working on a day-by-day basis with projects, corporate loans and different types of equity, need to be aware of the international accepted standards sector-by-sector to work with their clients or the companies in which they want to invest, for them to adhere to the highest standards.

All these tools can be used by FIs to strengthen and enhance their existing RMP.They can be integrated into a FI's EIAs, due diligence procedures, voting procedures at shareholder meetings, positive \& negative screening for (new) investment portfolios, and insurance premiums, among others. The different steps are further specified in Figure 13 and sections below. 


\subsubsection{Identifying important biodiversity areas}

When identifying if there are business risks at stake it is important to be aware if the presumed activities and impacts will occur in areas that have a significant biodiversity value.This includes, but is not limited to, areas of high endemism levels or high levels of species richness. There are a number of organizations and initiatives that have attempted to classify areas of specific biodiversity value through specific tools. These include, but are not limited to:

- Conservation International's Biodiversity Hotspots. ${ }^{\mathrm{kk}}$ The tool aims to provide an overview of the richest and most threatened reservoirs of plant and animal life on Earth.

- WWF's Ecoregions. It identifies a set of ecoregions whose conservation would achieve the goal of saving a broad diversity of the Earth's ecosystems. These ecoregions include those with exceptional levels of biodiversity, such as high species richness or endemism, or those with unusual ecological or evolutionary phenomena.

- World Database of Protected Areas. ${ }^{\mathrm{mm}}$ It provides the most comprehensive dataset on protected areas worldwide and is managed by UNEP-WCMC in partnership with the IUCN World Commission on Protected Areas (WCPA) and the World Database on Protected Areas Consortium.

- BirdLife's IBAs. ${ }^{\text {nn }}$ Their programme aims to identify, monitor and protect a global network of sites for the conservation of the world's birds and other biodiversity. The selection of Important Bird Areas (IBAs) has been a particularly effective way of identifying conservation priorities. IBAs are key sites for conservation - small enough to be conserved in their entirety and often already part of a protected-area network. They do one (or more) of three things:

- Hold significant numbers of one or more globally threatened species;

- Are one of a set of sites that together hold a suite of restricted-range species or biome-restricted species;

- Have exceptionally large numbers of migratory or congregatory species.
- Centres of plant diversity. ${ }^{84}$ Two hundred and fifty sites and areas that are important centres of plant diversity at a regional and global level.The compilers used expert knowledge, and mixed criteria emphasizing species richness and endemism.

These systems are very helpful in identifying regions and areas that have high biodiversity values. However, it is virtually impossible to rule out economic activities in areas that are recognized by the above-mentioned tools. Consider for example a WRI report that concluded that "...three quarters of active mines and exploratory sites overlap with areas of high conservation value and areas of high watershed stress". ${ }^{53}$ In order to be fully useful to the private sector, a certain refinement would be helpful to identify what areas are particularly important from a biodiversity perspective. In effect, this means that a tool should be as site-specific as possible (smallest geographical scale).

An effort led by Conservation International and BirdLife International is in the process of forming a consortium with various environmental NGOs and many representatives from the private sector to connect the various databases each organization has with respect to its own method or algorithm to classify areas of exceptional biodiversity and how this should be transformed into a format that would be useful for private business. The idea behind this initiative is to develop a "bottom-up" tool whereby data being gathered by each environmental NGO is transformed into such a format as to be useful to a wide range of private sectors that have an impact on ecosystems. Such a tool would describe in much more detail which spots contain exceptional biodiversity and/or endemism values, including possible guidance for companies how to minimize their impact on these areas. ${ }^{85}$

http://www.biodiversityhotspots.org/xp/Hotspots/

${ }^{11} \mathrm{http}$ ///www.worldwildlife.org/science/ecoregions/g200.cfm

$\mathrm{mm}$ http://www.unep-wcmc.org/wdpa/

${ }^{n n}$ http://www.birdlife.org/action/science/sites/index.htm

Figure 13. A general model to account for biodiversity risks in different segments of the financial sector

Gredit lending

Risk identification, risk evaluation and controlling

Rating $>$ Costing $>$ Pricing $>$ Monitoring $>$ Work-out Due diligence/EIA Engagement

- Benchmarks
Asset management

\begin{tabular}{|c|c|c|c|}
\hline Scree & His & any financial $v$ & lability \\
\hline $\begin{array}{c}\text { Exclusion } \\
\text { criteria }\end{array}$ & $\underset{\text { in-class }}{\text { Best- }}$ & Engagement & $\begin{array}{l}\text { Voting at } \\
\text { shareholder } \\
\text { meetings }\end{array}$ \\
\hline
\end{tabular}

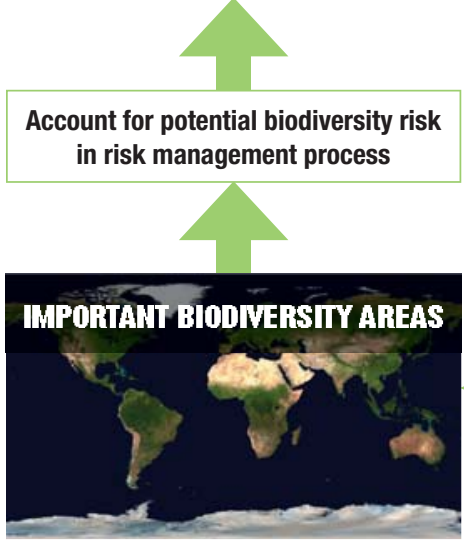

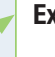

Existing risk management procedures

Account for potential biodiversity risk in risk management process
Insurance

\begin{tabular}{|c|c|}
\hline \multicolumn{2}{|c|}{ Insurance } \\
\hline $\begin{array}{c}\text { Assess insurability } \\
\text { Statistics Premium price }\end{array}$ & $\begin{array}{l}\text { Increase } \\
\text { premium }\end{array}$ \\
\hline & $\begin{array}{l}\text { Refuse } \\
\text { insurance }\end{array}$ \\
\hline
\end{tabular}

\section{2 .2}

Existing tools to use in risk management procedures: - CERES Principles (general)

- Biodiversity Benchmark (assest management)

- Equator Principles (project finance)

- VBDO Biodiversity Quickscan (general)

- UN Global Compact (general)

- Global Reporting Initiative (general)

\subsection{1}

Existing tools to assess important biodiversity areas:

- Cl: Biodiversity hotspots

- WWF: Ecoregions

- World Database on Protected Areas

- World Heritage Sites

- TNC: Natural Heritage Inventory

- Birdlife: Important Bird Areas 


\subsubsection{Tools developed for the private sector that factor-in biodiversity}

There is a wide variety of tools available for the private sector to enable them to incorporate environmental considerations within their business operations. Some of these tools specifically factorin biodiversity considerations. Others include it as one factor out of several (ESG) factors. Table 10 provides an overview of the different tools available that make reference to biodiversity in some way and which can be used by FIs to assess if a company is addressing biodiversity in its operations.

Each of these tools has its own strength in terms of focusing on a specific corporate segment (i.e. governance; strategy/policy; management and implementation; assurance and reporting).A preliminary attempt is made to point out how these tools can be used as indicators of biodiversity management/performance in the risk management processes of different types of financial services/products.

The Equator Principles and the Biodiversity Quick Scan focus specifically on the financial sector. These tools enable FIs to take account of biodiversity (i.e. their impact and/or how it can be reduced).

Most of these instruments and initiatives can function as indicators in different types of financial services, while others appear to be useful only for specific types of financial services.

\subsubsection{Industry standards and international conventions}

In addition to available tools that FIs can use for their operations, a number of FIs have indicated (during the interview survey) that they would greatly benefit by knowing what good sector-specific industry practices there are. In this way, they can refer to these standards when issuing loan contracts or advising clients what the best available industry guidelines, benchmarks and industry bodies are that they can follow in order hedge BBRs. The difficulty with sector-specific best management practices (BMPs) is that there are so many in certain sectors (e.g., for the tourism sector alone there are already 150 different types of certification). Table 11 provides an overview of some guidelines for those sectors that can be considered relevant for biodiversity. The list has been structured according to the following criteria:

- The sectors that are included in this table have been recognized by the European Bank of Reconstruction and Development (EBRD) and by F\&C Asset Management as having a high impact on the environment (EBRD) or biodiversity specifically (F\&C Asset Management).

- A distinction is made between tools that fully focus on biodiversity and those that factor-in biodiversity considerations as one element.

- Industry bodies are included to enable financial institutions to contact the respective industry representative body for further information.

Please note that this list is by no means definitive. Rather, it can be used as a simple overview by risk analysts, client relation managers, fund managers, etc to see what is available to base their policies and contract conditions on.

In addition to the sector-specific BMPs there are five wellknown and less well-known international conventions that are biodiversity-related and that FIs can use generally to align with international BMPs. These concern:

- Convention on Biological Diversity (CBD). ${ }^{\text {nnn }}$ This convention has three objectives: 1) The conservation of biological diversity; 2) the sustainable use of its components; and 3) the fair and equitable sharing of the benefits from the use of genetic resources.
- Convention on International Trade in Endangered Species of Wild Flora and Fauna (CITES). ${ }^{\circ 00}$ Its aim is to ensure that international trade in specimens of wild animals and plants does not threaten their survival.

- Convention on Migratory Species (CMS). ${ }^{\text {ppp }}$ Also know as the Bonn Convention, it aims to conserve terrestrial, marine and avian migratory species throughout their range.

- World Heritage Convention. ${ }^{\mathrm{qq} q}$ This convention seeks to encourage the identification, protection and preservation of cultural and natural heritage around the world considered to be of outstanding value to humanity.

- Ramsar Convention on wetlands. ${ }^{\text {rrr }}$ This treaty provides the framework for national action and international cooperation for the conservation and wise use of wetlands and their resources.

\subsection{Factors contributing to a successful integration of biodiversity into risk management procedures}

There are a number of factors that contribute to a successful integration of BBRs into a financial institution's risk management procedures. The following ones were highlighted by some FIs during the interview survey:

1. Not cost too much time. In order not to overburden the credit-lending and investment process it is important that any biodiversity tools to be incorporated should not cost account managers and analysts too much time to go through.

2. Needs to be easily implemented in existing business structures. Any additional tools should be easy to implement within existing risk management processes.

3. Be sector-specific and promote sustainable industry standards. One bank representative indicated that for most transactions clients or the bank are simply not aware of the bestmanagement practices (BMP) or sustainability guidelines for the sector. In addition she highlighted the need to develop an approach that was sector-specific, meaning that different guidelines or BMPs should apply for different sectors.

4. Operate in a level playing field. Though project finance typically only concerns a few percent of a bank's total revenue, it has been argued that its endorsement could only have been possible as $80 \%$ of worldwide project finance now operates under the EP umbrella. This means that banks are less afraid of losing a project to a competitor as it is very likely it also operates under the same guidelines. Therefore, in order for any biodiversity-related procedure or tool to be successful it helps when several FIs adopt similar procedures or tools thereby creating a level playing field.

“A TOOL TO ACCOUNT FOR BIODIVERSITY RISKS SHOULD NOT OVERBURDEN THE INVESTMENT PROCESS; RATHER IT SHOULD COMPLEMENT IT.”

Nelson Switzer, Royal Bank of Canada

"FOR AN INSTRUMENT TO BE SUCCESSFUL, IT HAS TO BE I) SIMPLE TO IMPLEMENT; 2) PROMOTE STANDARDS; 3) BE SECTOR-SPECIFIC; AND 4) CREATE A LEVEL-PLAYING FIELD.” Maria Anne van Dijk, Fortis

nnn $w$ ww.biodiv.org

${ }^{\circ 00}$ www.cites org

ppp www.cms.int

qqq http://whc.unesco.org/

rrr www.ramsar.org 


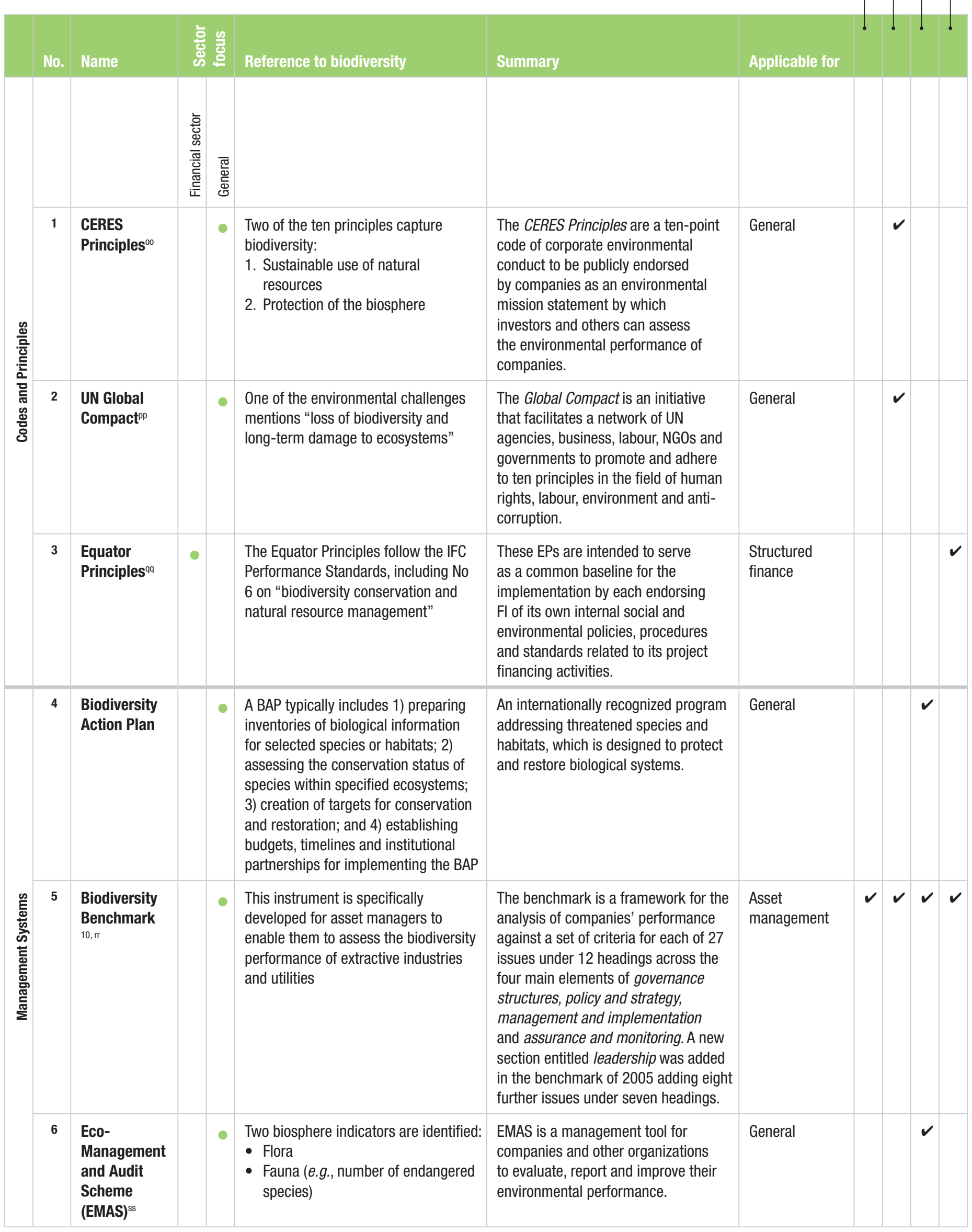




\begin{tabular}{|c|c|c|c|c|c|c|c|c|}
\hline 7 & ISO $14001^{\mathrm{tt}}$ & & - & $\begin{array}{l}\text { Biodiversity is identified as one of the } \\
\text { environmental aspects }\end{array}$ & $\begin{array}{l}\text { This tool provides companies with a } \\
\text { guide to develop an Environmental } \\
\text { Management System (EMS) for which } \\
\text { they can be certified accordingly. }\end{array}$ & General & $\checkmark$ & $\checkmark$ \\
\hline 8 & ISO 14031 & & - & $\begin{array}{l}\text { Biodiversity is identified as one of the } \\
\text { environmental aspects }\end{array}$ & $\begin{array}{l}\text { A standard that describes a process } \\
\text { for measuring the environmental } \\
\text { performance of an organization. }\end{array}$ & General & $\boldsymbol{V}$ & $\checkmark$ \\
\hline 9 & $\begin{array}{l}\text { Global } \\
\text { Reporting } \\
\text { Initiative } \\
\text { (GRI) }^{\text {ü }}\end{array}$ & & - & $\begin{array}{l}\text { - EN 11: Location and size of land } \\
\text { owned, leased, managed in, or } \\
\text { adjacent to, protected areas and } \\
\text { areas of high biodiversity value } \\
\text { outside protected areas. (Core) } \\
\text { - EN 12: Description of significant } \\
\text { impacts of activities, products, and } \\
\text { services on biodiversity in protected } \\
\text { areas and areas of high biodiversity } \\
\text { value outside protected areas. } \\
\text { (Core) } \\
\text { - EN 13: Habitats protected or } \\
\text { restored. (Additional) } \\
\text { - EN 14: Strategies, current actions, } \\
\text { and future plans for managing } \\
\text { impacts on biodiversity. (Additional) } \\
\text { - EN 15: Number of IUCN Red List } \\
\text { species and national conservation } \\
\text { list species with habitats in areas } \\
\text { affected by operations, by level of } \\
\text { extinction risk. (Additional) }\end{array}$ & $\begin{array}{l}\text { The GRI Reporting Framework is } \\
\text { intended to serve as a generally } \\
\text { accepted framework for reporting } \\
\text { on an organization's economic, } \\
\text { environmental, and social performance } \\
\text { (labour practices and human rights). }\end{array}$ & General & & $\checkmark$ \\
\hline 10 & $\begin{array}{l}\text { VBDO } \\
\text { Biodiversity } \\
\text { Quick Scan }{ }^{16}\end{array}$ & - & & $\begin{array}{l}\text { A framework to quickly measure the } \\
\text { biodiversity impact of a company, } \\
\text { using a number of steps }\end{array}$ & $\begin{array}{l}\text { The toolkit, developed by CREM } \\
\text { consultancy for the Dutch Association } \\
\text { of Investors for Sustainable } \\
\text { Development (VBD0), follows a generic } \\
\text { step-by-step process to assess if } \\
\text { impacts on biodiversity are to be } \\
\text { expected and if so to get into dialogue } \\
\text { with the respective company. }\end{array}$ & Credit lending & $\checkmark$ & \\
\hline
\end{tabular}

${ }^{\text {oo }}$ http://www.ceres.org/coalitionandcompanies/principles.php pp http://www.globalcompact.org/

qq www.equator-principles.com

${ }^{\mathrm{rr}}$ For an up to date version of the biodiversity benchmark, please

visit the Insight Investment website: http://www.insightinvestment.

com/Responsibility/Engagement/ecosystem_management.asp

ss http://ec.europa.eu/environment/emas/index_en.htm

tt www.iso.org

${ }^{\mathrm{uu}}$ www.globalreporting.org 


\begin{tabular}{|c|c|c|c|c|c|}
\hline \multirow[b]{2}{*}{ Sector } & \multicolumn{2}{|c|}{ Fully biodiversity focused } & \multicolumn{2}{|c|}{ Biodiversity included as one factor } & \multirow[b]{2}{*}{ Industry bodies } \\
\hline & $\begin{array}{l}\text { Sustainability } \\
\text { guidelines }\end{array}$ & Benchmarks & $\begin{array}{l}\text { Sustainability } \\
\text { guidelines }\end{array}$ & $\begin{array}{l}\text { Benchmarks - } \\
\text { certification }\end{array}$ & \\
\hline Forestry \& Paper & & & $\begin{array}{l}\text { - Sustainable Forestry } \\
\text { Initiative (SFI) } \\
\text { - The Forest Dialogue } \\
\text { Review } \\
\text { - } \text { HSBC Forestry }^{86} \\
\text { Guideline }^{87}\end{array}$ & & $\begin{array}{l}\text { - The Forest Dialogue } \\
\text { (TFD) } \\
\text { - International Tropical } \\
\text { Timber Organization } \\
\text { (ITTO)ww } \\
\text { - } \text { Global Forest } \\
\text { Industry CEO Forum } \\
\text { - } \text { Forest Stewardship } \\
\text { Council (FSC) }\end{array}$ \\
\hline Oil \& Gas & $\begin{array}{l}\text { - Energy \& Biodiversity } \\
\text { Initiative (EBI) }\end{array}$ & $\begin{array}{l}\text { - } \text { Biodiversity } \\
\text { Benchmark (Fauna \& } \\
\text { Flora International/ } \\
\text { Insight Investment }{ }^{10} \\
\text { - } \text { A survey by F\&C } \\
\text { asset management }{ }^{88}\end{array}$ & & $\begin{array}{l}\text { - Goldman } \\
\text { Sachs Energy } \\
\text { Environmental } \\
\text { and Social Index } \\
\left(\text { GSEES) }{ }^{20}\right.\end{array}$ & $\begin{array}{l}\text { - International } \\
\text { Petroleum Industry } \\
\text { Environmental } \\
\text { Conservation } \\
\text { - Association (IPIECA) }{ }^{\mathrm{xx}} \\
\text { International } \\
\text { Association of Oil and } \\
\text { Gas Producers (OGP) }\end{array}$ \\
\hline Mining \& Metals & & $\begin{array}{l}\text { - Biodiversity } \\
\text { Benchmark (Fauna \& } \\
\text { Flora International/ } \\
\text { Insight Investment }{ }^{10} \\
\text { - } \text { A survey by F\&C } \\
\text { asset management }{ }^{88}\end{array}$ & $\begin{array}{l}\text { - The Extractive } \\
\text { Industries Review } \\
\text { (EIR by the World } \\
\text { Bank)yy } \\
\text { - Mining, Minerals } \\
\text { and Sustainable } \\
\text { Development } \\
\text { Working Group } \\
\text { (MMSD) } \\
\text { - Guidance for the } \\
\text { Mining Industry in } \\
\text { Raising Awareness } \\
\text { and Preparedness for } \\
\text { Emergencies at the } \\
\text { Local Level (ICMM \& } \\
\text { UNEP) }\end{array}$ & & $\begin{array}{l}\text { - International Council } \\
\text { on Mining and Metals } \\
\text { (ICMM)zz } \\
\text { - Global Mining } \\
\text { Initiative (GMI) }\end{array}$ \\
\hline $\begin{array}{l}\text { Building \& } \\
\text { Construction \& } \\
\text { Utilities }\end{array}$ & & $\begin{array}{l}\text { - Biodiversity } \\
\text { Benchmark (Fauna \& } \\
\text { Flora International/ } \\
\text { Insight Investment }{ }^{10}\end{array}$ & $\begin{array}{l}\text { - GRI sector } \\
\text { supplement (Energy } \\
\text { Utilities) } \\
\text { - UNEP Dams and } \\
\text { Development } \\
\text { Project }^{\text {an }} \\
\text { - Cement Sustainability } \\
\text { Initiative Charter } \\
\text { - HSBC Freshwater } \\
\text { Infrastructure } \\
\text { Guideline }^{91}\end{array}$ & & $\begin{array}{l}\text { - World Commission } \\
\text { on Dams (WCD)cc } \\
\text { - Cement Sustainability } \\
\text { Initiative (CSI by the } \\
\text { WBCSD)ddd }\end{array}$ \\
\hline Tourism & CBD guidelines & & $\begin{array}{l}\text { - Prince of Wales } \\
\text { International } \\
\text { Business Leaders } \\
\text { Forum/Conservation } \\
\text { International: } \\
\text { Sustainable Hotel } \\
\text { - Siting, Design and } \\
\text { Construction }^{92} \\
\text { - WTO/UNEPF } \\
\text { Sustainable Tourism } \\
\text { Guide for Policy } \\
\text { Makers }^{93}\end{array}$ & - The Green Globeeee & $\begin{array}{l}\text { - International } \\
\text { Business Leaders } \\
\text { Forum }{ }^{\text {fff }} \\
\text { - The International } \\
\text { Tourism } \\
\text { Partnershipggg }\end{array}$ \\
\hline
\end{tabular}




\begin{tabular}{|c|c|c|c|c|}
\hline $\begin{array}{l}\text { Agriculture; Food } \\
\text { processors \& } \\
\text { producers; Food \& } \\
\text { Drug retailers }\end{array}$ & $\begin{array}{l}\text { - IFC-WWF Better } \\
\text { Management } \\
\text { Practices } \\
\text { Programmenh } \\
\text { - The Sustainable Food } \\
\text { Labiii }^{\text {hii }} \\
\text { - Biodiversity and } \\
\text { Agricultural } \\
\text { Commodities } \\
\text { Programme (BACP)ij }\end{array}$ & $\begin{array}{l}\text { - Rainforest Alliance } \\
\text { Certified Labelkkk }\end{array}$ & $\begin{array}{l}\text { - Marine Stewardship } \\
\text { Council }\end{array}$ & $\begin{array}{ll}\text { - } & \text { Roundtable on } \\
\text { Sustainable Palm Oil } \\
\text { (RSPO)III } \\
\text { - } \text { Roundtable on } \\
\text { Sustainable Soy } \\
\text { - } \\
\text { Marine Stewardship } \\
\text { Council (MSC) } \\
\text { - The Sustainable } \\
\text { Agriculture Initiative } \\
\text { (SAI) }{ }^{\mathrm{mmm}}\end{array}$ \\
\hline
\end{tabular}

vv www.aboutsfi.org

ww http://www.itto.or.jp

$\mathrm{xx}$ www.ipieca.org

yy http://web.worldbank.org/WBSITE/EXTERNAL/TOPICS/

EXTOGMC/ 0,,contentMDK:20605112 menuPK:336936 pagePK:14

8956 piPK:216618 theSitePK:336930,00.html

${ }^{2 z}$ www.icmm.com

aaa www globalreporting org

bbb http://www.wbcsdcement.org/land.asp

ccc www.dams.org

ddd www.wbcsdcement.org

eee www.greenglobe21.com

fff ${ }^{2} w w$.ibfl.org

ggg www.internationaltourismpartnership.or

hhh http://www.ifc.org/ifcext/enviro.nsf/AttachmentsByTitle/art_

CCF-BMPIntro/\$FILE/BMP-Intro.pdf

iii www.glifood.org

iji http://www.ifc.org/ifcext/enviro.nsf/Content/Biodiversity_BACP

kkk http://www.rainforestalliance.org/programs/agriculture/

certification/index.html

Ill www.rspo.org

$\mathrm{mmm}$ www saiplatform or 
Though the bigger part of this report focused on biodiversity from a risk perspective, and though biodiversity risks can likely be more significant from a financial perspective, there are several biodiversity business opportunities (BBOs) that can create both leverage for conservation as well as make good business sense.A number of them are outlined below.

1) Providing debt or equity to businesses that have a positive (direct or indirect) influence on biodiversity. A forthcoming report by IUCN and Shell ${ }^{94}$ provides an overview of various BBOs that either directly or indirectly contribute to conservation. These are outlined in Table 12. It also includes estimates for potential market growth by 2010 and 2050 .

With respect to securities, there is an interesting initiative underway concerning long-term forestry bonds that have an indirect positive impact on biodiversity. It was initiated by Henderson Global Investors and is receiving financial support from the IFC (see Box IX).

2) Due diligence and advisory services. Being able to understand the relation to ecosystems and its associated risks and opportunities to a diverse range of private sectors enables FIs (e.g., investment banks) to carry out biodiversity-related due diligence and project advisory services. Niall Cameron, global head of traded products at ABN AMRO, for example, outlined in the January 2007 issue of the Banker ${ }^{95}$ that the bank's clients may be affected by environmental change or water shortages and that the bank can provide help to hedge these risks.

3) Biodiversity-related insurance cover. With new legislation coming up in Europe, to hold operators directly responsible for impacts on flora and fauna, insurance and reinsurance firms that are willing to understand the underlying risks associated with it have the opportunity to explore new markets. Another example concerns the Panama Canal.Around 65\% of the insurance premium of the shipping companies using the canal is environment-related, such as too little water or delays because of regular dredging. Reforestation will drastically cut insurers exposure to BBRs.95

4) Government-induced opportunities. Biodiversity conservation was traditionally perceived as the responsibility of the government, but increasingly involves the private sector in a variety of ways. The financial sector can take advantage of this

\section{Box IX: Eco-securitisation}

This initiative, initiated by Mark Campanale of Henderson Global Investors and established mid-2006 by the International Finance Corporation with the backing of the UK's Department for International Development, aims to link the long-term outlook associated with sustainable management of natural resources with the funding capacity and requirements of asset backed securitisation (ABS). ABS is a capital market financial instrument that can be described as the financing or re-financing of income-yielding assets (such as forests) by packaging them into a tradable form such as through the issue of bonds. Focusing on the forestry sector, it boils down to offering the cash-flow that will be generated from sustainably managing a certain patch of forest over a certain period to investors (securitizing the asset), who consequently provide the upfront transfer of funds to the forest owners in order to be able to manage the forests sustainably over a period of time. Investors in ABS enjoy legal and structured preference over traditional investors. Forest owners would need to be able to spot potential demand amongst growers, run the business (of sustainable forestry) in an effective and efficient way, and if enough cash-flow can be generated over a time period to pay off the investment, the forest owners would have the residual value of the investment. Other than the forestry sector, this approach has the possibility of financing other types of "natural infrastructure" such as fisheries and water supply. by partnering with governments to share the risk of investing in or providing loans to biodiversity-friendly businesses. Examples can include fiscal advantages for biodiversityrelated investments (see Box $\mathrm{X}$ ) or a guarantee fund whereby investors are given certain guarantees on their investment pre-hand, which are backed by the government. In the recently launched "Potsdam Initiative - Biological Diversity 2010" the environmental ministers of the G8 countries express their urge to "... enhance financing from existing financing instruments and explore the need and the options of additional innovative mechanisms to finance the protection and sustainable use of biological diversity, together with the fight against poverty. In this context we will examine the concept and the viability of payments for ecosystem services".

5) Access to capital. Especially for banks and other FIs in emerging markets, they can increase their chances of funding by International Financial Institutions (e.g., International Finance Corporation - IFC), which require more and more strict environmental and social risk guidelines, when they provide evidence of having the capacity in-house to deal with environmental risks. ${ }^{96}$

6) Conservation land as a result of default or debt work-out. Should a bank acquire a significant amount of biodiversitysensitive land as a result of default or debt work-out situations, collaborations with NGOs, local conservation organizations or the government might be helpful in finding suitable (conservation) purposes for the land, while the bank remains owner of the land. This could be used at the same time to bolster a financial institution's reputation or be used for marketing purposes.

\section{Box X. The Netherlands's fiscal green funds}

In order to stimulate environmentally friendly investments in the Netherlands, the Dutch ministries of VROM (Housing, Spatial Planning and the Environment), LNV (Agriculture, Nature and Food Quality) and Finance, in collaboration with the Dutch banking sector, initiated a green fiscal policy in 1995 to make investment in green funds attractive for private investors. Banks and specialized green funds provide low interest loans to entrepreneurs who engage in activities such as biological agriculture, nature development, sustainable/green housing and renewable energy technologies. Some of these investments have a positive contribution on local biodiversity. While the return on investment is generally lower with green funds, the government has provided a fiscal advantage for those who invest in these green funds (such as the Rabo Groenbank - by Rabobank) to make it financially attractive. The initiative has been a success in the Netherlands and various major banks, such as ABN AMRO, ING bank, Fortis, ASN Bank and the Triodos bank, are now offering green bonds or other green products. As of December 2005, the total invested capital amounted to $€ 1.5$ billion, of which $€ 282$ million has been allocated to the project category "nature, forests and landscapes". The difference between the Dutch green funds and SRI is that investors in SRI funds invest in regular companies and therefore do not receive a fiscal advantage.

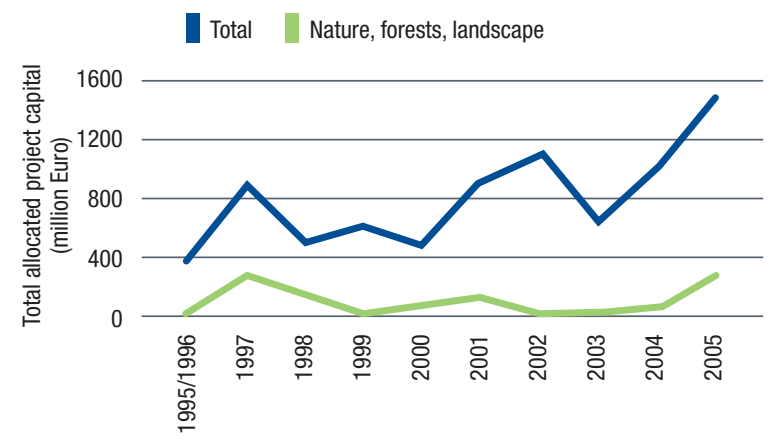

Source: : SenterNovem, 2006. The Green Funds Scheme - Annual Report 2005. Utrecht. 
Though a number of BBOs have been identified, some of which could provide new growth opportunities for investors, actual investments by the private sector have remained limited to date. Several factors have been recognized that contribute to this: ${ }^{94}$

1) Absence of adequate policy frameworks. A good example here concerns so-called markets for ecosystem/environmental services. In places where regulatory frameworks have been established, such as for the European Carbon Market or the US markets for conservation banking and wetland mitigation banking, demand for ecosystem services and biodiversity is being captured through an (artificial) cap or floor. In places where regulatory support has remained absent it appears to be much more difficult to capture demand and initiate biodiversity business initiatives.

2) Lack of multi-stakeholder ownership. Involve several types of stakeholders, such as governments, NGOs and businesses, where each stakeholder has its own strengths and weaknesses when it comes to commoditizing biodiversity.
3) Lack of coupling business development and/or technical assistance with appropriate finance. The challenge is to integrate biodiversity management into standard due diligence and project implementation processes, while ensuring that these additional measures do not unduly constrain the market.

4) Absence of flexible financial models. Various financing instruments can be used to promote biodiversity business, using combinations of debt and equity finance, on a commercial, non-commercial or 'sub-commercial' basis. Some practitioners indicate a preference for debt or quasi-debt finance, due to concerns about barriers that exist with equity investors on biodiversity business. However, there is no strong consensus on this point. More experimentation and analysis is required.

5) Lack of performance indicators. Both process- and output indicators are critical to the success of biodiversity business. However, these must be fit-for-purpose, simple and costeffective

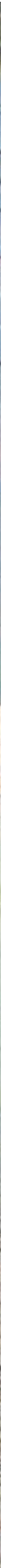


Table 12. Summary of direct and indirect markets for ecosystem services and potential for growth ${ }^{94}$

\begin{tabular}{|c|c|c|c|c|}
\hline & Ecosystem market & $\begin{array}{l}\text { Current size } \\
\text { (US\$ per annum) }\end{array}$ & $\begin{array}{l}\text { Potential size - } 2010 \\
\text { (US\$ per annum) }\end{array}$ & $\begin{array}{l}\text { Potential size - } 2050 \\
\text { (US\$ per annum) }\end{array}$ \\
\hline \multirow{5}{*}{ 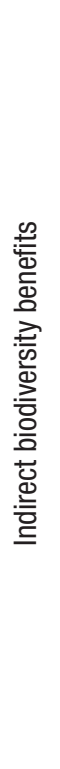 } & Certified Agriculture and Fisheries & $\$ 26,000$ million in global sales; $\$ 21,000$ million & $\$ 60,000$ million & $\$ 200,000$ million \\
\hline & $\begin{array}{l}\text { Carbon Sequestration through } \\
\text { Forestry (e.g., Kyoto, land use, land- } \\
\text { use change and forestry (LULUCF)) }\end{array}$ & $\begin{array}{l}\$ 100 \text { million (much of this in developing } \\
\text { countries) }\end{array}$ & $\begin{array}{l}\$ 1,500 \text { million (if EU ETS } \\
\text { allows sinks in by 2008) }\end{array}$ & $\$ 6,000$ million \\
\hline & $\begin{array}{l}\text { Certified Products (Timber and } \\
\text { NTFPS) }\end{array}$ & $\begin{array}{l}\text { Forestry Stewardship Council (FSC) alone } \\
\text { estimated at } \$ 5,000 \text { million }\end{array}$ & $\$ 15,000$ million & $\$ 50,000$ million \\
\hline & $\begin{array}{l}\text { Government Payments for Water- } \\
\text { Related Ecosystem Services }\end{array}$ & $\begin{array}{l}\$ 1,000 \text { million New York City watershed scheme } \\
\text { - \$150 million, water-related payments } \$ 240 \\
\text { million; EQUIP estimate } 50 \% \text { for water-related } \\
\text { - } \$ 500 \text { million; Mexico PES program \$15 million; } \\
\text { Costa Rica PES Program } \$ 5 \text { million; China state } \\
\text { PES program } \$ 1+\text { billion? }\end{array}$ & $\$ 3,000$ million & $\$ 20,000$ million \\
\hline & $\begin{array}{l}\text { Private Watershed Management } \\
\text { Payments }\end{array}$ & $\begin{array}{l}\$ 5 \text { million. Many public payments for } \\
\text { environmental services (PES) are partially } \\
\text { public. In Costa Rica and Ecuador for example } \\
\text { approximately } 30 \% \text { are private funds from } \\
\text { electric utilities (paid from their revenues). }\end{array}$ & $\$ 50$ million & $\$ 10,000$ million \\
\hline \multirow{6}{*}{ 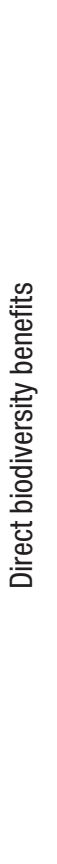 } & Bioprospecting & $\$ 17.5-30$ million & \$35 million & $>\$ 500$ million \\
\hline & $\begin{array}{l}\text { Regulatory Driven Ecosystem Offsets } \\
\text { (including US Wetland Mitigation } \\
\text { Banking) }\end{array}$ & $\begin{array}{l}\$ 200 \text { million (just private for profit wetland and } \\
\text { stream; } \$ 1,000 \text { million total (including in-lieu fee } \\
\text { etc.) Unknown how many ecosystem offsets are } \\
\text { driven by ElA regulation in developing countries }\end{array}$ & $\begin{array}{l}\$ 600 \text { million (banks); } \\
\$ 1,500 \text { million total }\end{array}$ & $\begin{array}{l}\$ 2,000 \text { million (banks); } \\
\$ 3,000 \text { million total }\end{array}$ \\
\hline & $\begin{array}{l}\text { Regulatory Driven Species Offsets } \\
\text { (including US Conservation Banking) }\end{array}$ & $\begin{array}{l}\$ 45 \text { million in the US. Program just begun in } \\
\text { Australia and possibly similar programme in } \\
\text { France, size unknown }\end{array}$ & $\$ 65$ million & \$200 million \\
\hline & $\begin{array}{l}\text { Voluntary Conservation Payments } \\
\text { and Biodiversity Offsets }\end{array}$ & $\begin{array}{l}\$ 20 \text { million (increased if money flowing through } \\
\text { conservation organizations is included) }\end{array}$ & \$25 million & $\begin{array}{l}\$ 150 \text { million } \\
\text { - if corporations take } \\
\text { to the concept }\end{array}$ \\
\hline & $\begin{array}{l}\text { Government Conservation Payments } \\
\text { and Biodiversity Offsets }\end{array}$ & $\begin{array}{l}\$ 3,000 \text { million - just flora and fauna oriented } \\
\text { programmes (not including water and soil } \\
\text { conservation); in developing countries the } \\
\text { government involvement may be through state } \\
\text { electricity, water, road agencies }\end{array}$ & $\$ 4,000$ million & $\$ 10,000$ million \\
\hline & $\begin{array}{l}\text { Land Trusts, Conservation Easements } \\
\text { (and expenditure by NGOs for } \\
\text { conservation) }\end{array}$ & $\begin{array}{l}\$ 6,000 \text { million in US alone. Size and use of } \\
\text { easements in developing countries is unclear }\end{array}$ & $\$ 10,000$ million & $\$ 20,000$ million \\
\hline
\end{tabular}




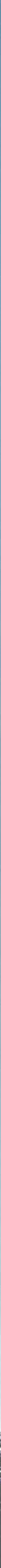




\section{Conclusions}

There is a growing business case for financial institutions (FIs) to address and mitigate biodiversity-related risks (BBRs). Results from an interview survey among 26 financial institutions, other private sectors and NGOs revealed that 19 out of 26 respondents (> 70\%) believed FIs are exposed to reputational risk. The report also provides a wide range of cases indicating that FIs can be exposed to a wide range of other risks as well, both directly and indirectly.

FIs can be directly exposed to reputational risk, liability risk or new regulations. For example, the environment ministers of the G8 countries and the five major newly industrializing countries launched the "Potsdam Initiative - Biological Diversity 2010", on 17 March 2007, where they outline that they will "approach the financial sector to effectively integrate biodiversity into its decision making". FIs can become indirectly exposed to BBRs from their investment portfolios, loans and insurance products to companies that have a major impact on ecosystems. This particularly concerns:

- Companies depending on ecosystem goods and services. These include for example the tourism, fisheries, forestry and the agricultural sectors

- Clients having (high) impacts on ecosystems. These can be subdivided into companies with direct footprints on ecosystems, such as the oil \& gas, mining, and construction sector, as well as sectors that have significant impacts through their supply chains, such as the food retail sector.

Goldman Sachs outlined that since the oil \& gas sector will have to look for more remote offshore gas and oil fields in the future, which are more complex exploration and production areas, these types of companies will very likely become more exposed to BBRs. When these types of companies come under increasing biodiversity-related scrutiny, for example through new liability regulations, pressures from NGOs, concerns by policy makers or shifting consumer preferences, it may impact their ability to pay back loans (increased risk for default), impact their shareholder value or lead to an increase in insurance claims.

Although BBRs are likely to be more significant in terms of the financial consequences, there are also biodiversity business opportunities (BBOs) to be captured. These include, but are not limited to:

1) Growing markets for certified sustainable produced commodities, such as for wild fish, aquaculture or agricultural products. Estimates suggest a market size of about US $\$ 60$ billion annually by 2010 . There are also market opportunities for biodiversity offsets, biocarbon, NTFPs, PES and biofuels among others. Estimates for market sizes range from US\$35 million-10 billion annually by 2010 .

2) Due diligence or advisory services to clients that need assistance in biodiversity-sensitive project and transactions.

3) Biodiversity-related insurance cover. For example, around $65 \%$ of the insurance premium of the shipping companies using the Panama Canal is environment-related, such as covering for too little water or delays because of regular dredging. Reforestation along the slopes of the canal will drastically cut insurers' exposure to BBRs.

4) Government-induced opportunities. The Dutch government for example triggered demand amongst private investors to invest in green funds. Total capital invested in 2005 amounted to $€ 1.5$ billion, of which $€ 282$ million has been allocated to the project category "nature, forests and landscapes".

5) Conservation land as a result of default or debt work-out. Should a bank acquire a significant amount of biodiversitysensitive land as a result of default or debt work-out situations, collaborations with NGOs, local conservation organizations, or the government might be helpful in finding suitable (conservation) purposes for the land, while the bank remains owner of the land. At the same time, this could be used to bolster a financial institution's reputation or be used for marketing purposes

At present, though the issue has hardly appeared on the radar screen of the financial sector in general, there are already a number of major banks that have started to integrate biodiversity (as part of other extra-financial issues) into their risk management procedures (RMP) or other business operations. An assessment of 11 commercial and investment banks revealed that a considerable number of banks have already started to go beyond the Equator Principles to develop sector-specific guidelines that they apply to an increasing number of credit and investment products. Rabobank appears to be a leader in biodiversity, as they are applying a CSR tool as of the $1^{\text {st }}$ of February 2007 to all their lending activities where three of the ten guiding principles refer to biodiversity to some extent. The bank's client relation managers and risk analysts are obliged to use this tool for all products. And Goldman Sachs recently adopted the Biodiversity Benchmark (developed by Fauna \& Flora International and Insight Investment), which they use for their investment decision making.

For those FIs that understand the materiality of the issue and that want to identify how to integrate biodiversity into their risk management procedures (RMP), thereby mitigating any adverse BBRs, the report outlined a general procedure. The procedure provides an overview of existing tools to:

1) Identify biodiversity important areas. A number of NGOs have developed (spatial) tools that identify important biodiversity areas, although most areas are quite broad. Work is underway at present to develop a biodiversity tool for the private sector that identifies much more in detail where biodiversity hotspots are situated.

2) Identify what tools have been developed for the private sector that factor-in biodiversity. These can be used by FIs, both in their own RMP or as indicators for their clients to assess their ability to address biodiversity.

3) Identify sector-specific industry guidelines and international conventions. Several FIs indicated during the interview survey that they would greatly benefit by knowing what the bestmanagement practices are sector-by-sector. By knowing this, they can inform their clients, as part of their conditions in issuing contracts or use it in developing sector guidelines.

To further support the integration of biodiversity into financial business models, a number of FIs outlined general criteria that will contribute to successfully integrating any biodiversity-related tools into their RMP.These include:

1) Any tool should be easy-to-use by those working with it on a daily basis, such as client relation managers, risk analysts and fund managers.

2) It should be possible to implement it within existing business structures in order not to overburden the credit or investment process.

3) Any tool should be sector-specific and identify sustainable industry standards (e.g., multilateral conventions, industry guidelines, benchmarks).

4) Ideally a tool should be adopted by a wide range of FIs thereby operating in a level playing field (such as for project finance, where a level playing field was created when a large number of major banks voluntarily committed themselves to the Equator Principles). 


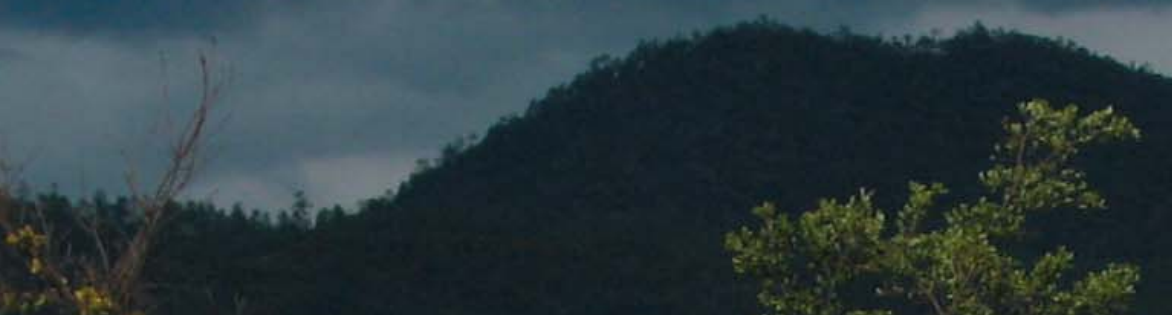

ser

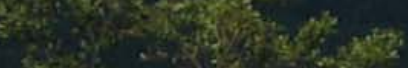

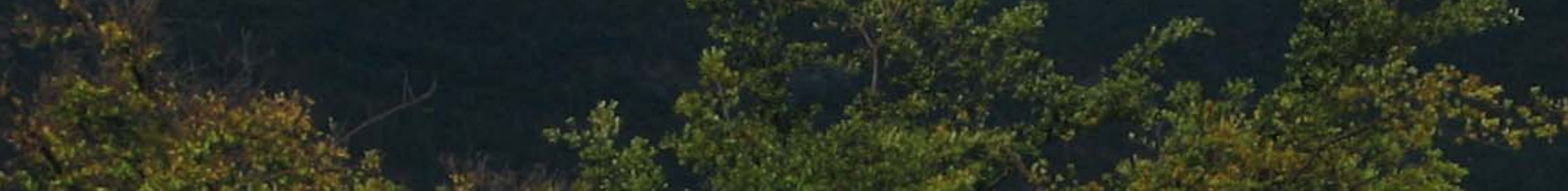

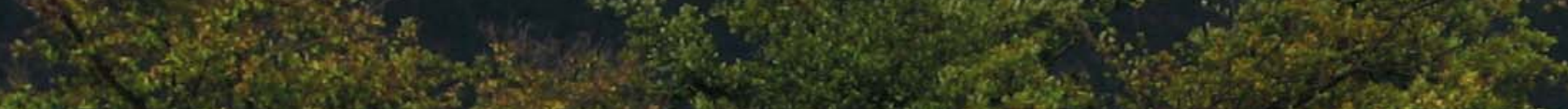
H.7.5.

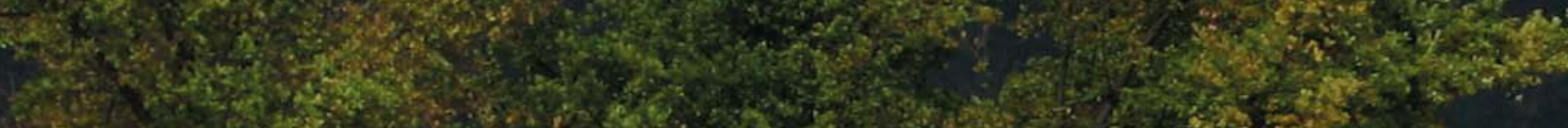
at. Y.

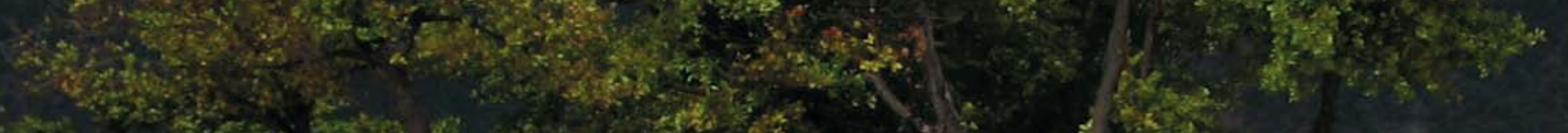

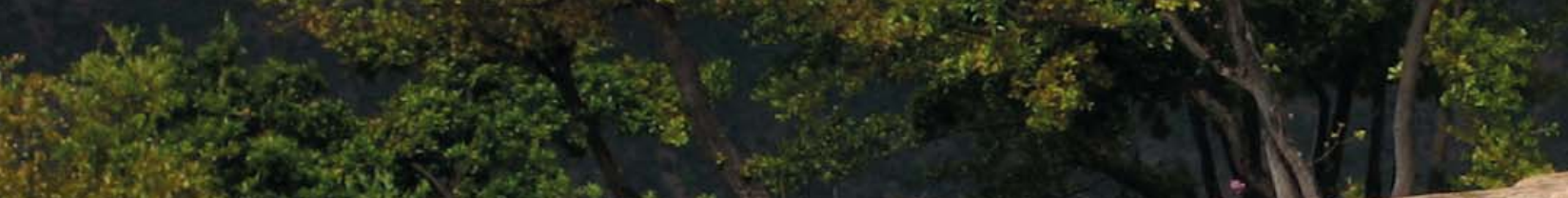

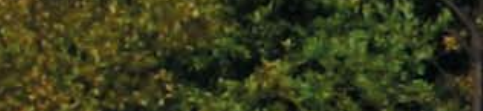

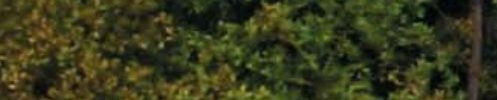

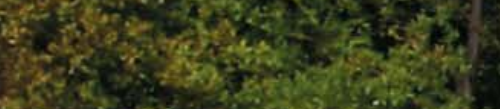

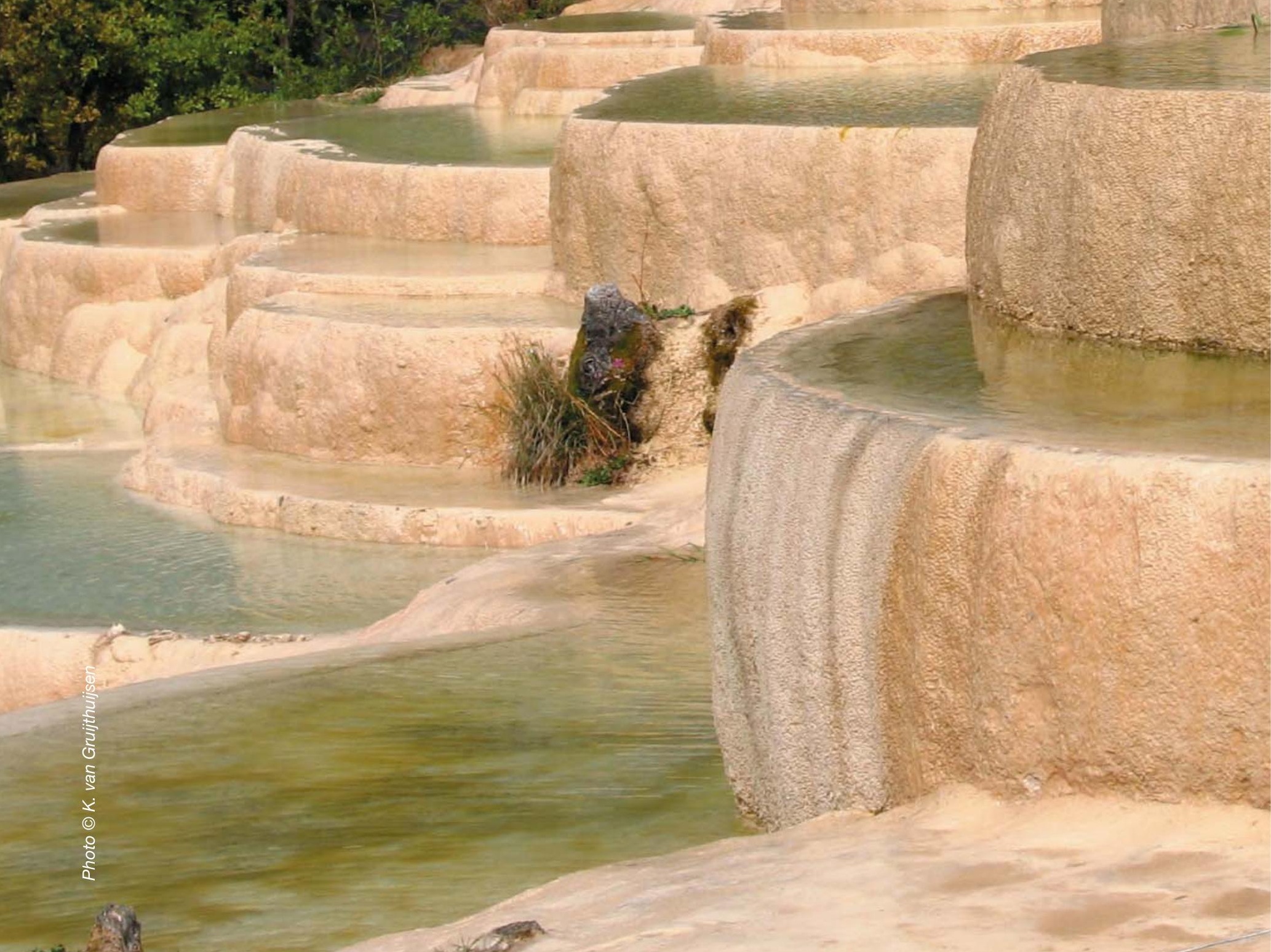




\section{Recommendations}

Despite the fact that there is undoubtedly greater interest in biodiversity issues in the financial sector, there is clearly a huge effort needed to continue to build the biodiversity business case and increase the awareness of biodiversity as a significant business factor within the financial sector.The following recommendations can contribute to this:

\section{Continue to build the biodiversity business case for Fls}

1) A Stern-like review ${ }^{97, \text { sss }}$ of the economic costs of biodiversity loss and benefits of biodiversity conservation can lift the issue up the international political and business agenda. The need for such a study was also highlighted during the G8 meeting of environment ministers in Potsdam, March 2007. There is a big role to play here for government agencies, research institutes, as well as for the NGO community.

2) Greater focus on quantifying the business case from a risk perspective. Though this project provided a wide-range of case studies expressing evidence of the business case, it is important to link biodiversity business risks (BBRs) as much as possible to tangible financial metrics, such as default risk, shareholder value or market capitalization, in a systematic way.

3) With respect to biodiversity business opportunities (BBOs), a stronger effort should be undertaken from the NGO community (in collaboration with FIs that are recognizing potential business opportunities) towards identifying BBOs, as well as start pilot projects to assess their financial viability.

\section{Diversify communication \& raise awareness of the materiality of biodiversity to Fls}

4) Diversify the communication channels about the business case for biodiversity to FIs. Governments, multilateral institutions and NGOs as well as those FIs that have already started to address biodiversity are examples of stakeholders that can participate in such a process.

5) Building capacity within FIs to mitigate BBRs and identify BBOs. As this issue is rather new for the sector there is a need for FIs to build capacity to deal with this emerging issue.This can for example be achieved through training of staff, engaging in partnerships with NGOs and multilateral organizations or by hiring consultancies that possess the technical capacity. UNEP FI has already initiated a working stream on the issue.

\section{Develop tools that day-to-day users can use}

6) Biodiversity should be integrated in such a way that it becomes practical by people using such tools on a day-by-day basis. This includes, for example, client relation managers, credit analysts, and fund mangers.

\section{Focus on the entire financial sector}

7) Focus on other segments of the financial sector.This project focused on commercial banking, asset managers/investors and insurance. In an effort to increase awareness throughout the entire sector, there is a business rationale to include other segments of the financial sector as well.

- Though this study focused on (institutional) investors to a certain extent, there is a clear need to increase the focus on this segment of the financial sector. Due to the long term horizons of their investments, pension funds, insurance firms, and other institutional investors have a clear business rationale to incorporate biodiversity into their risk management procedures and investment decision-making.

- Similar efforts should be made to engage credit rating agencies in this process, by identifying possibilities to incorporate biodiversity into the "credit-worthiness" assessments for projects, companies, and countries.

- Since biodiversity is often still regarded as a public good, governments, which control huge amounts of public bonds and public pensions, even have a special obligation to assess possibilities to integrate biodiversity into their risk management procedures and investment decision-making.

sss The Stern review outlined that future loss of GDP as a result of climate change is projected to be in the range of $5 \%$ to even $20 \%$ each year, whereas the costs of action now is estimated to cost about $1 \%$ GDP per year. 
Asset manager. A company that manages pools of capital on behalf of third parties.

Areas of high biodiversity value. ${ }^{\text {ttt }}$ Areas not subject to legal protection but recognized for important biodiversity features by a number of governmental and non-governmental organizations. These include habitats that are a priority for conservation (often defined in National Biodiversity Strategies and Action Plans prepared under the Convention on Biological Diversity). In addition, several international conservation organizations have identified particular areas of high biodiversity value.

Commercial bank. This type of bank accepts and manages deposits from households, firms and governments and uses a portion of those deposits to earn interest by making loans and holding securities.

Corporate Social Responsibility (CSR). An "umbrella" concept that not only benefits a company's financial bottom line, but also its environmental and social bottom line. CSR initiatives should go beyond minimum legal compliance. ${ }^{98,99}$

Corporate Value Chain. This depicts all activities a company engages in while doing business. It can be used as a framework to identify the positive and negative social impacts of those activities. ${ }^{33}$

Critical Natural Habitat. This concept is for example used by Goldman Sachs in their environment policy. It includes 1) existing protected areas and areas officially proposed by governments as protected areas (e.g., reserves that meet the criteria of the World Conservation Union (IUCN) classifications); 2) areas initially recognized as protected by traditional local communities (e.g., sacred groves); 3) sites that maintain conditions vital for the viability of these protected areas (as determined by the environmental assessment process); and 4) sites identified on supplementary lists prepared by the World Bank or an authoritative source determined by IFC's Environment Division.

Ecosystem. ${ }^{100}$ A contraction of "ecological" and "system", refers to the collection of biotic and abiotic components and processes that comprise and govern the behaviour of some defined subset of the biosphere. Elements of an ecosystem may include flora, fauna lower life forms, water and soil.

Extra-financial issues. These are fundamentals that have the potential to impact a company's financial performance or reputation in a material way, and include environmental, social and governance issues. However, these issues are generally not part of traditional fundamental analysis in investment research.

Habitat. It is essentially the environment - at least the physical environment - that surrounds (influences and is utilized by) a species population. ${ }^{101}$

High Conservation Value Forest. High Conservation Value Forests are for example used by ABN AMRO for their sector-guidelines. It includes the following attributes: a) forest areas containing globally, regionally or nationally significant concentrations of biodiversity values (e.g., endemism, endangered species, refugia); and/or large landscape level forests, contained within, or containing the management unit, where viable populations of most if not all naturally occurring species exist in natural patterns of distribution and abundance; b) forest areas that are in or contain rare, threatened or endangered ecosystems; $c$ ) forest areas that provide basic services of nature in critical situations (e.g., watershed protection); d) forest areas fundamental to meeting basic needs of local communities (e.g., subsistence, health) and/or critical to local communities' traditional cultural identity (areas of cultural, ecological, economic or religious significance identified in cooperation with such local communities).

Insurance company. A company that sells insurance, which can be defined as the equitable transfer of the risk of a potential loss, from one entity to another, in exchange for a premium, to its clients.

Invasive species. This refers to a subset of introduced species or non-native species that are rapidly expanding outside of their native range. Invasive species can alter ecological relationships among native species and can affect ecosystem function and human healthError! Bookmark not defined.

Institutional investor. An investor, such as a bank, insurance company, retirement fund, hedge fund, or mutual fund, that is financially sophisticated and makes large investments, often held in very large portfolios of investments

Investment bank. This type of bank provides a range of financial and investment related services, advising clients on security issues, acquisitions and disposals of businesses, arranging and underwriting new issues, distributing securities and running fund management companies.

Non-Timber Forest Products (NTFPs). These types of products comprise all goods derived from forests of both plant and animal origin other than timber. NTFPs contribute to household income and subsistence and are of cultural importance in many rural societies. ${ }^{102}$

Payments for Environmental Services. This constitutes a voluntary transaction where a well-defined ecosystem service (or a land-use likely to secure that service) is being 'bought' by a (minimum one) ecosystem service buyer from a (minimum one) ES provider if and only if the ES provider secures ES provision (conditionality). ${ }^{103}$

Protected area. ${ }^{\text {uu }}$ A geographically defined area that is designated, regulated, or managed to achieve specific conservation objectives.

Recourse/non-recourse. Refers to the right, in an agreement, to demand payment from the person who is taking on an obligation. A full recourse loan refers to the right of the lender to take any assets of the borrower if repayment is not made. Non-recourse is when the pay-back of a certain loan is fully determined by the revenue generated by a specific activity/project and the bank or lender is not entitled to access the borrower's principal assets in the event of default

Reinsurance company. Reinsurance involves the risks borne by insurance companies being taken on by another company or companies. In essence, reinsurers insure insurers.

Sell-side research houses. These firms buy and sell stock for their customers and make a profit through fee, commissions and research.

Sustainable Development. Development that meets the needs of the present without compromising the ability of future generations to meet their own needs. ${ }^{104}$

Stakeholder. From a corporate perspective, a stakeholder can be defined as "any group or individual who can affect or is affected by the achievements of the company's objectives". ${ }^{105}$ 
Annex l: Companies and experts consulted

Interview survey: All companies and organizations were surveyed through telephone conversations, unless otherwise stated.

\begin{tabular}{|l|l|}
\hline Financial Institutions (FIs) & Contact \\
\hline 1. ABN AMRO, Banco Real (Brazil) & Christopher Wells, Cristiane Ronza \\
\hline 2. ASN Bank (Netherlands) & Piet Sprengers \\
\hline 3. Barclays (UK) & Chris Bray \\
\hline 4. F\&C Asset Management (UK) & Robert Barrington \\
\hline 5. Christian Brothers Investment Services (USA) & Julie Tanner \\
\hline 6. Fortis (Netherlands) & Maria Anne van Dijk \\
\hline 7. Goldman Sachs (USA/UK) & Sarah Forrest, Marc Fox \\
\hline 8. Henderson Investmentwv (UK) & Mark Campanale \\
\hline 9. International Finance Corporation (USA) & Juan Jose Dada \\
\hline 10. Rabobank (Netherlands) & Bart-Jan Krouwel, Hans Biemans \\
\hline 11. Royal Bank of Canada (Canada) & Nelson Switzer \\
\hline 12. WestLB (Germany) & Foster Deibert, Marcus Rehm \\
\hline Other stakeholders & Contact \\
\hline 1. Alcoa & John Gardner \\
\hline 2. BankTrack & Johan Frijns \\
\hline 3. CERES & Chris Fox \\
\hline 4. Conservation International (Cl) & Assheton Carter \\
\hline 5. Earthwatch Institute & Chris Perceval \\
\hline 6. Fauna and Flora International & Annelisa Grigg \\
\hline 7. Friends of the Earth (FOE) & Michelle Chan-Fishel \\
\hline 8. Hoi Ping Ventures/ASrIA & Alexandra Tracy \\
\hline 9. International Council on Mining and Metals (ICMM) & Andrew Parsons \\
\hline 10. Philanthropy capital & Bernard Mercer \\
\hline 11. Rio Tinto & David Richards \\
\hline 12. The Nature Conservancy (TNC) & Josh Knights \\
\hline 13. World Business Council on Sustainable Development (WBCSD) & James Griffiths \\
\hline
\end{tabular}

${ }^{\mathrm{vvv}}$ Questions were answered by means of e-mail.

Other experts (consulted during September 2006-February 2007)

\begin{tabular}{|l|l|}
\hline 1. World Conservation Union (IUCN, Pakistan) & Contact \\
\hline 2. Convention on Biological Diversity (CBD) & Bhim Adhikari \\
\hline 3. Shell & Nicolas Bertrand \\
\hline 4. UNDP & Deric Quaile \\
\hline 5. CREM & Philipp Kauffmann \\
\hline 6. UNEP FI & Wijnand Broer \\
\hline 7. INCAE & Heidi Mayhew \\
\hline 8. Swiss Government & Edgar Rojas \\
\hline 9. De Vermogensmeesters & Julien Haarman \\
\hline
\end{tabular}


Table 13 provides an overview of benchmarks and rating systems that are already available to screen companies on their environmental (and biodiversity) sustainability. It can be used as a reference by financial institutions, researchers and other stakeholders that have an interest to know what instruments are currently available. Second, these instruments could serve as indicators in risk assessment procedures of asset managers to screen companies on their biodiversity performance

The instruments that have been included share two characteristics:

- Focus on the financial sector: The tool is either designed for the financial sector specifically or generally for the private sector (which includes of course the financial sector).

- Focus on biodiversity: Since biodiversity can be regarded as part of the wider environmental spectrum, the initial focus of this overview was to screen for instruments that focus on addressing environmental issues in general. However, of the tools that are incorporated, the focus was placed on detecting if biodiversity-related issues were addressed as well and if so, how.

The following conclusions can be drawn from this table:

- The stock-related rating systems have generally been developed to measure how the major companies in the world are moving on the sustainability road.They are rather general by nature, tend to focus on the private sector in general and the outcomes are freely available on the internet.

- The larger share of the systems included in this overview are screening ranking methods developed by individual companies (e.g., consultancies) and (non) commercial research institutes. Some of them also tend to provide an overview of how groups of companies (or sectors) are performing on environmental sustainability issues. In addition, some are focused on individual companies and these companies can indicate which factors or company departments should be taken into account as well as if the information will be freely available or remain internally classified.

- In total this review revealed 19 benchmark and rating systems that focus on or take account of environmental issues. Please note, however, that this list is not definitive. Leipziger (2003), ${ }^{108}$ for example, provides an overview of 30 CSR tools and/or statements

- Most of these benchmarking tools, however, have been developed for the private sector in general, rather than for the financial sector specifically.

- The Environment Index (developed by Business in the Community - BiTC) is the only benchmarking tool which has incorporated biodiversity. 


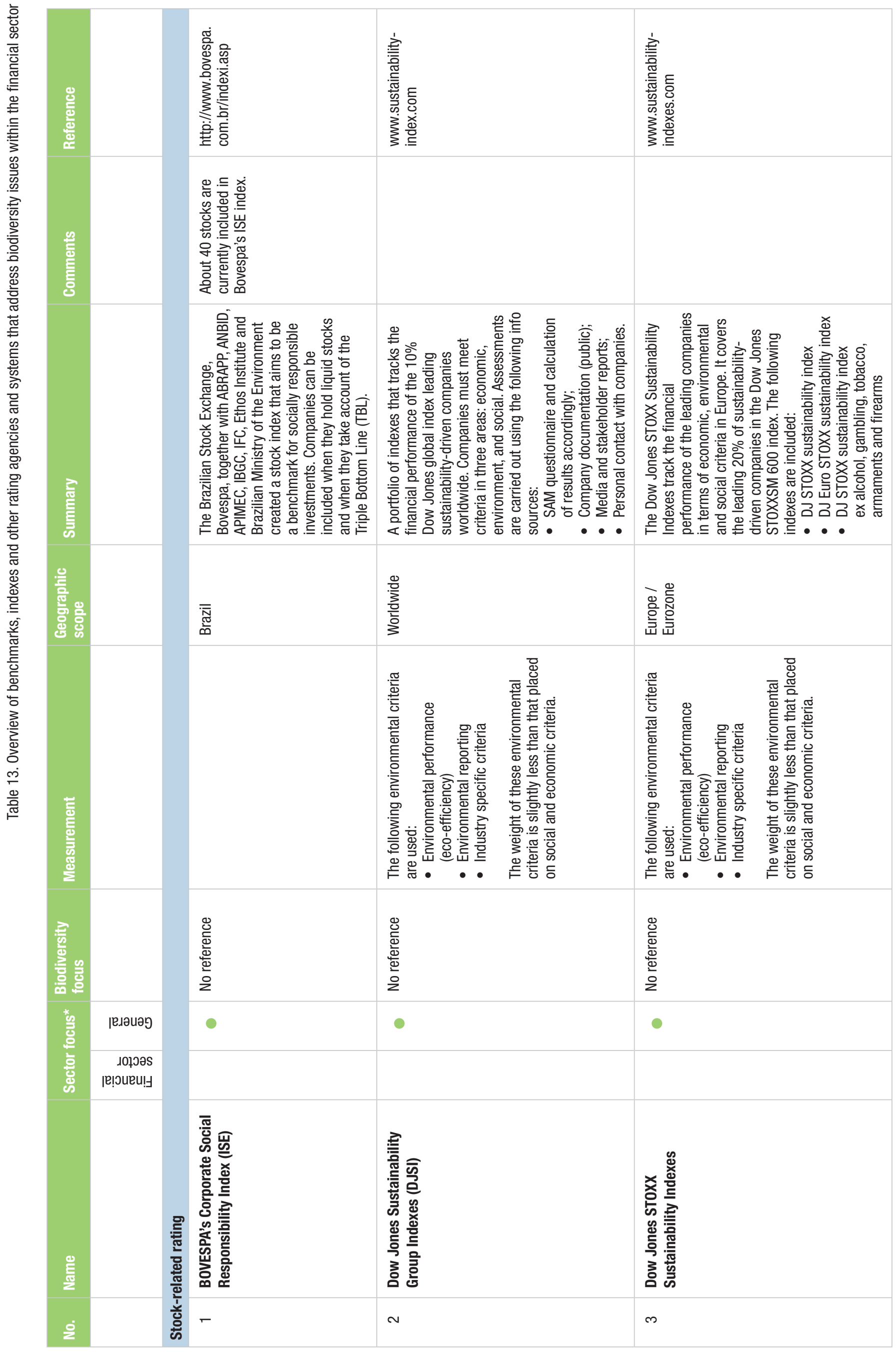




\begin{tabular}{|c|c|c|c|}
\hline 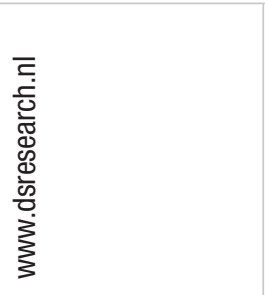 & 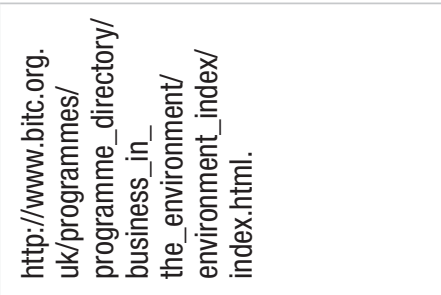 & 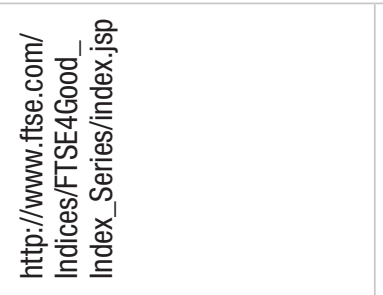 & 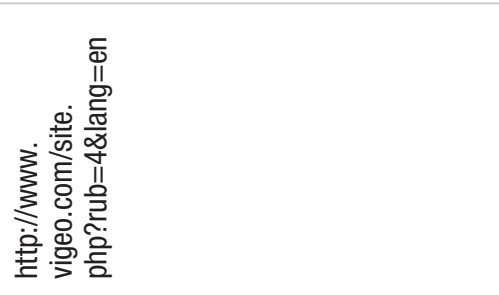 \\
\hline & 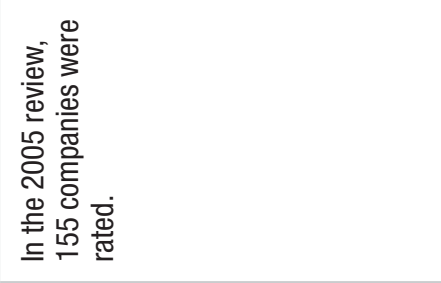 & & \\
\hline 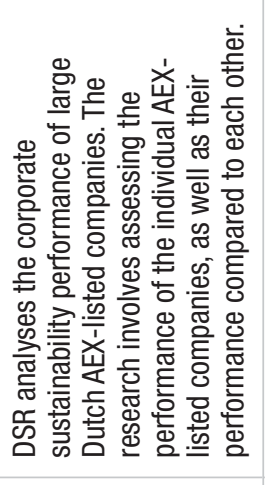 & 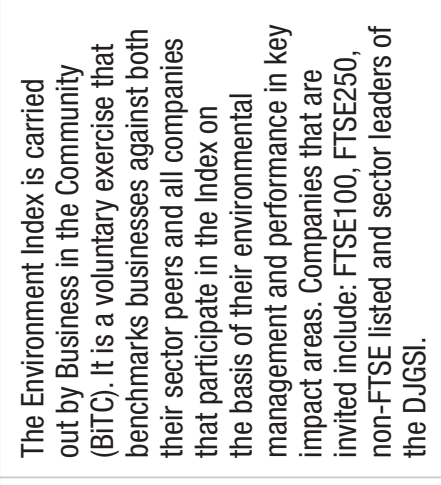 & 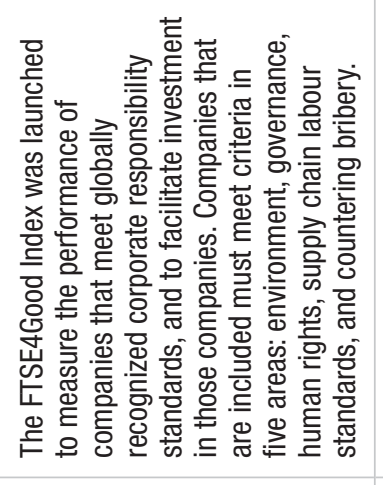 & 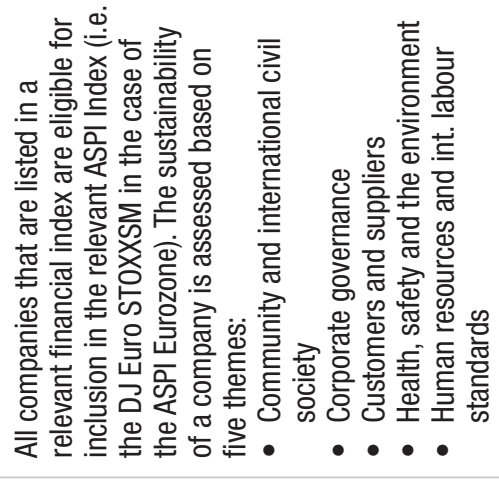 \\
\hline 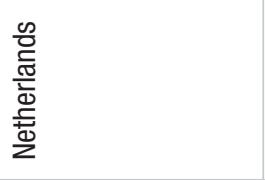 & $\begin{array}{l}\text { 흘 } \\
\text { 莺 } \\
\text { 旁 }\end{array}$ & 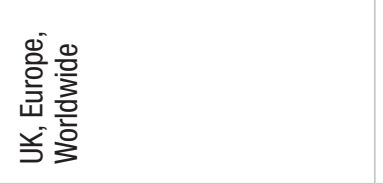 & $\begin{array}{l}\frac{0}{3} \\
\frac{30}{3} \\
3\end{array}$ \\
\hline 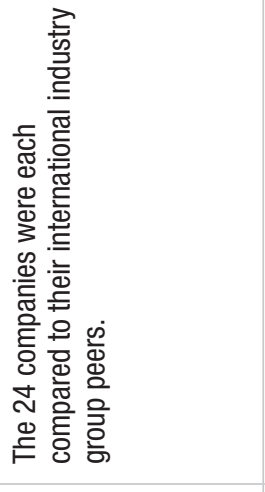 & 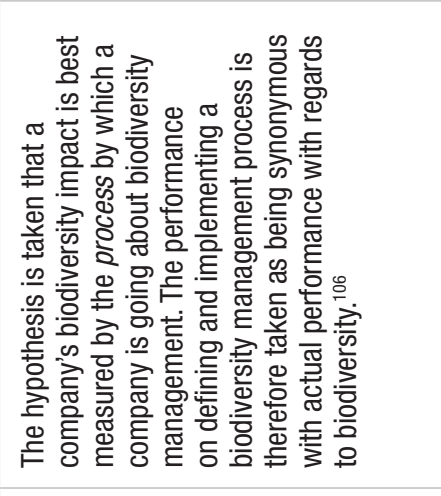 & 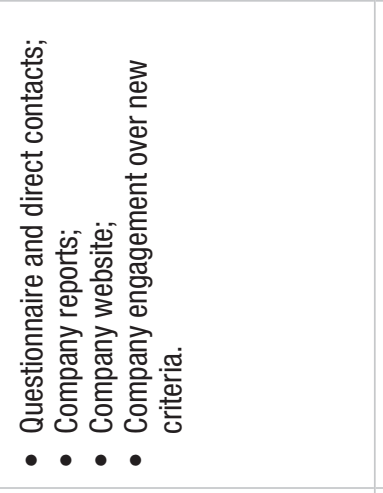 & 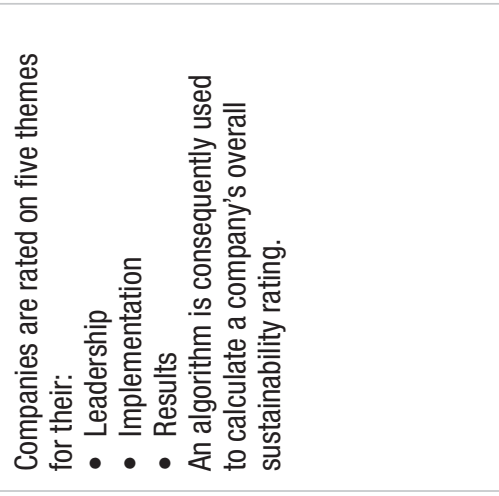 \\
\hline 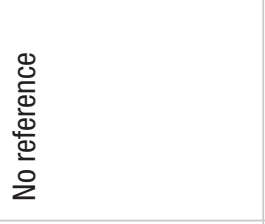 & 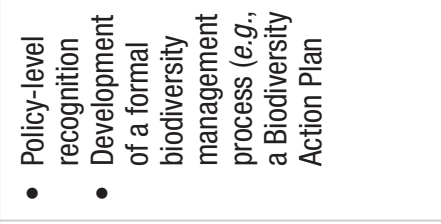 & 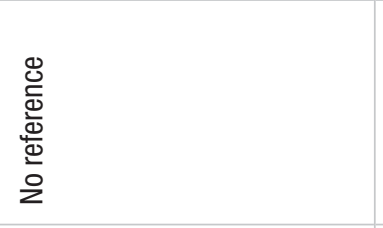 & 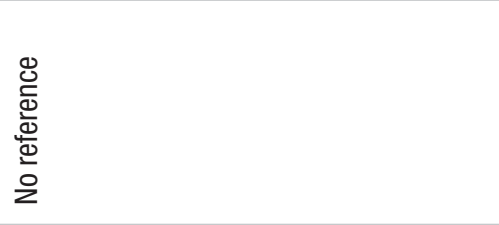 \\
\hline • & - & • & - \\
\hline 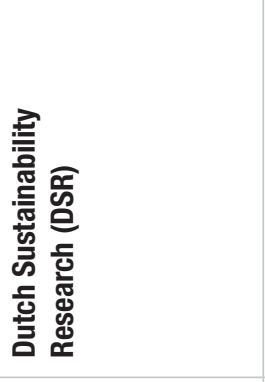 & 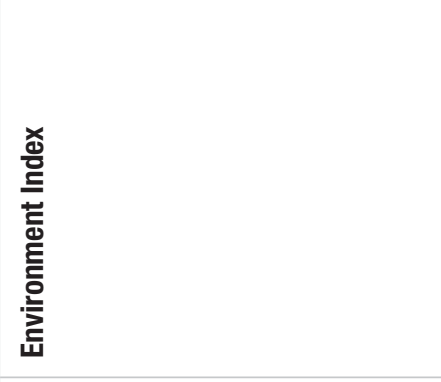 & 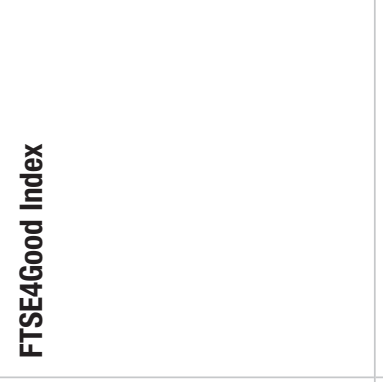 & 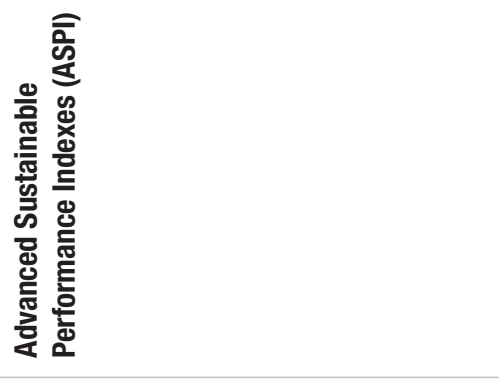 \\
\hline$\sigma$ & مص & 0 & $\wedge$ \\
\hline
\end{tabular}




\begin{tabular}{|c|c|c|c|c|c|}
\hline 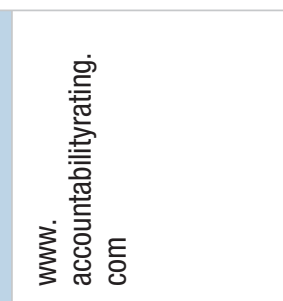 & 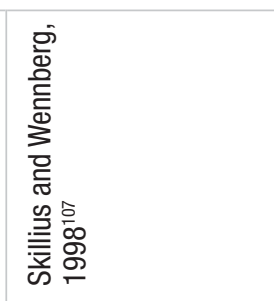 & 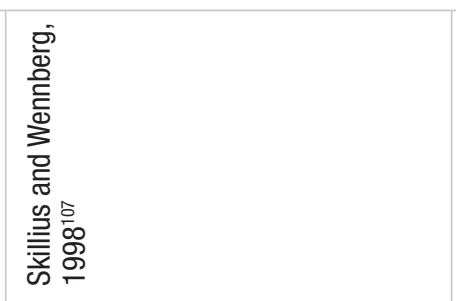 & 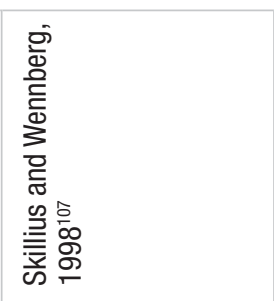 & 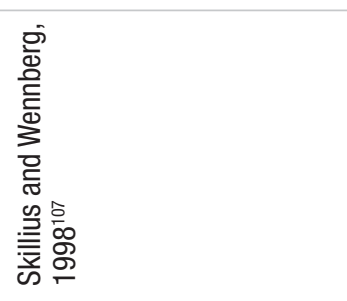 & \\
\hline 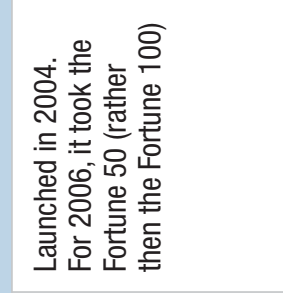 & 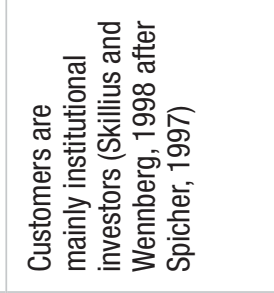 & 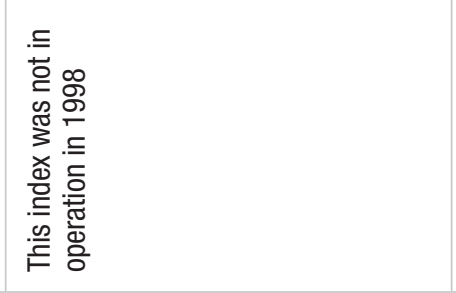 & & 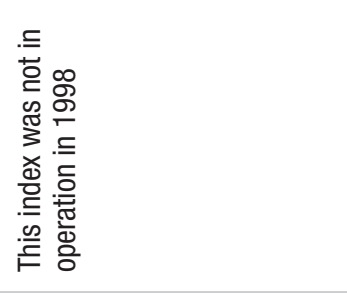 & \\
\hline 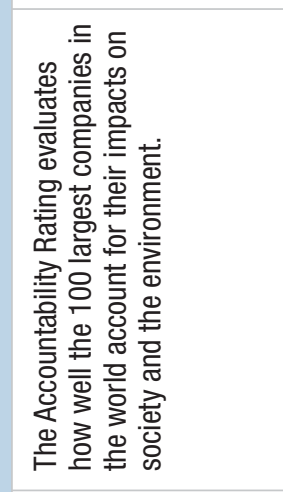 & 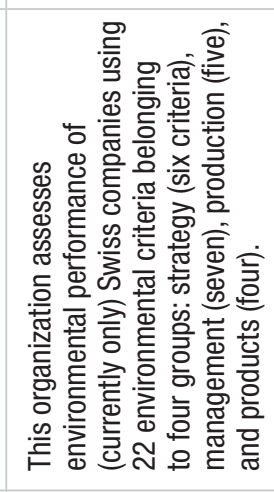 & 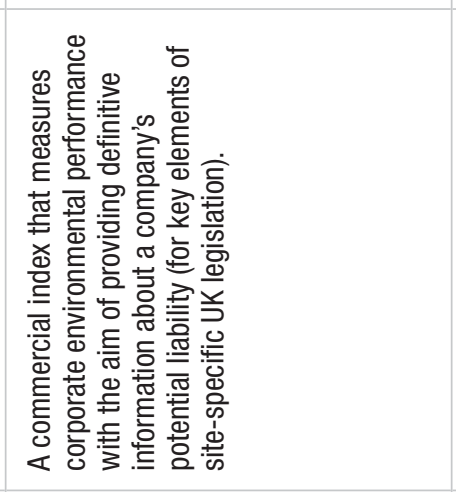 & 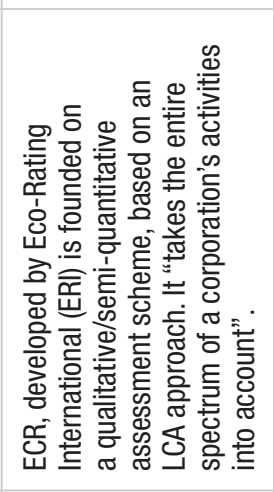 & 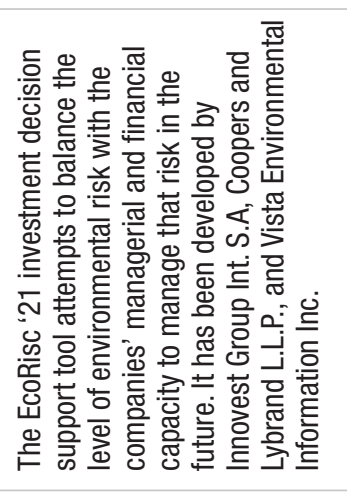 & 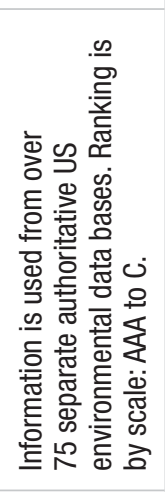 \\
\hline 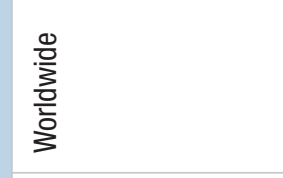 & 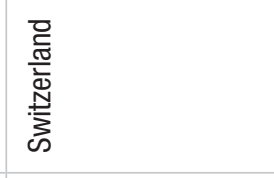 & $\begin{array}{l}\text { 을 } \\
\text { 产 }\end{array}$ & & & \\
\hline 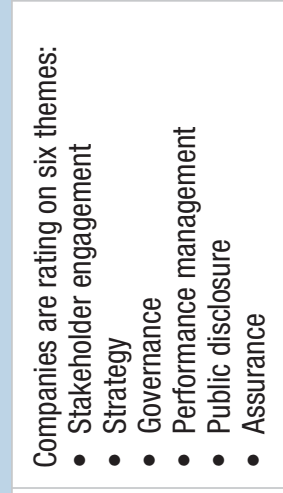 & 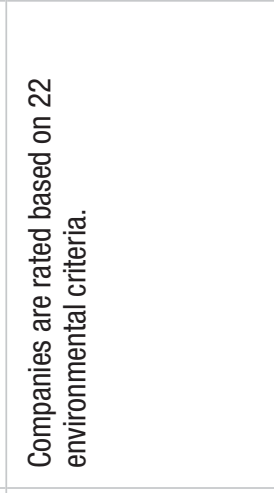 & 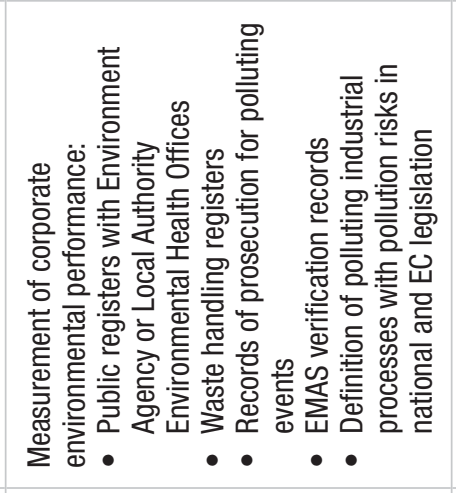 & & 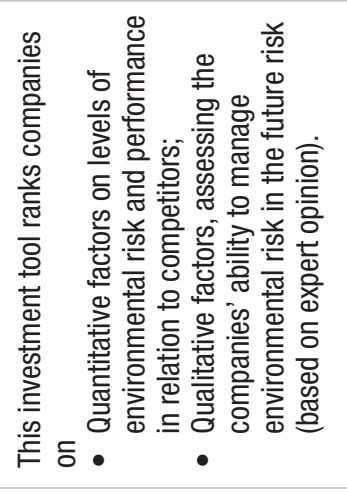 & \\
\hline 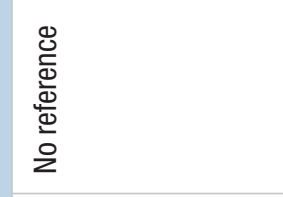 & 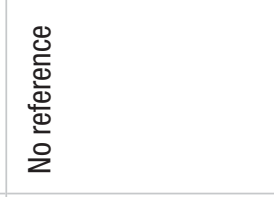 & 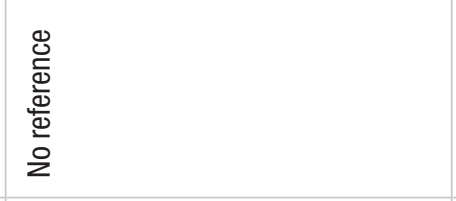 & 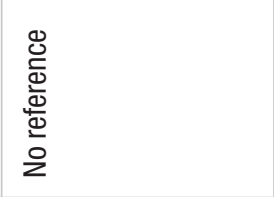 & 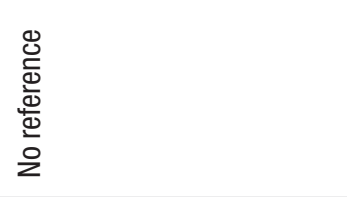 & \\
\hline \multirow[t]{2}{*}{ • } & & • & • & $\bullet$ & \\
\hline & $\bullet$ & & & & \\
\hline 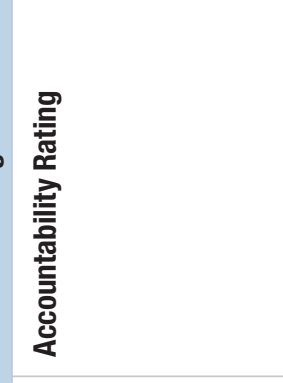 & 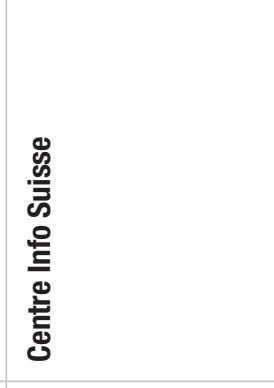 & 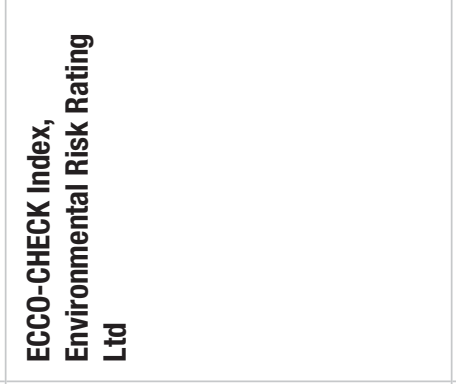 & 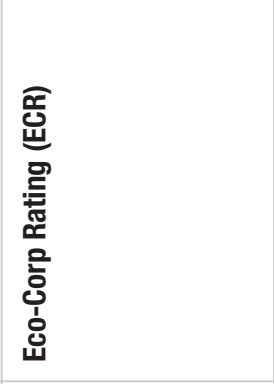 & 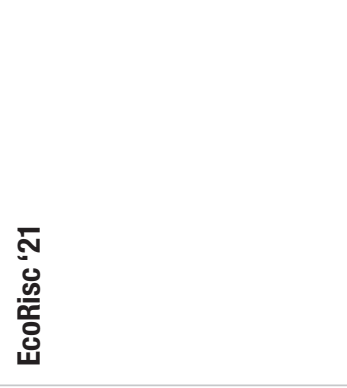 & \\
\hline$\infty$ & 0 & $\stackrel{\circ}{\circ}$ & $F$ & $\simeq$ & \\
\hline
\end{tabular}




\begin{tabular}{|c|c|c|c|c|c|}
\hline 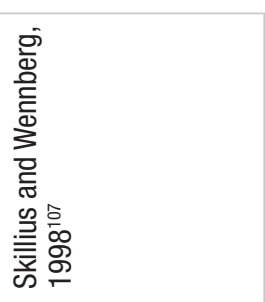 & 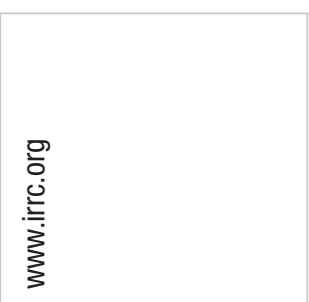 & 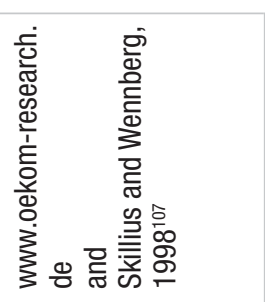 & 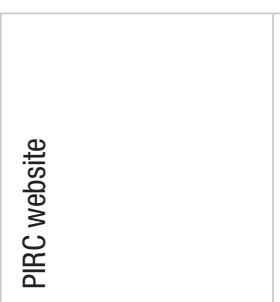 & 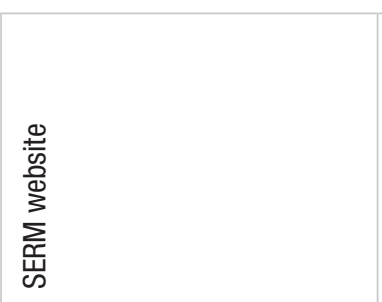 & 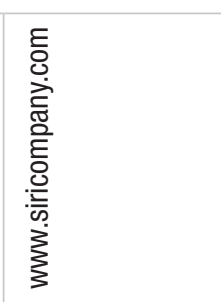 \\
\hline 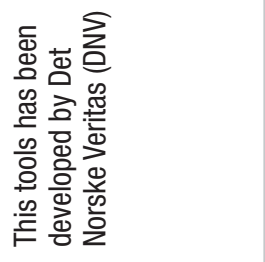 & 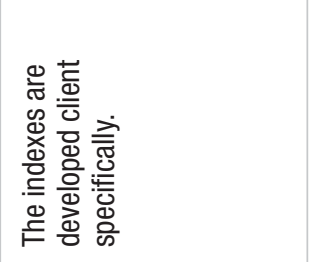 & & & 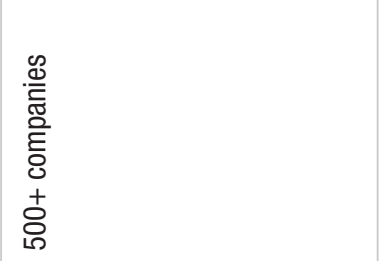 & \\
\hline \multirow[t]{2}{*}{ 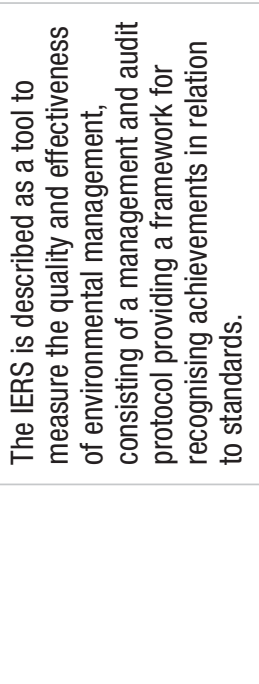 } & 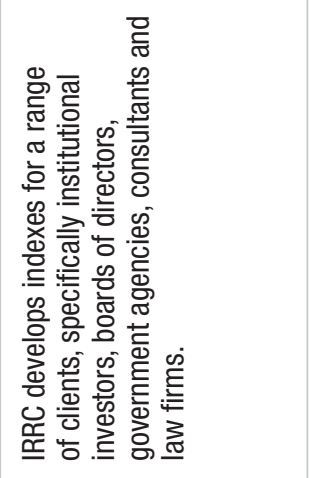 & 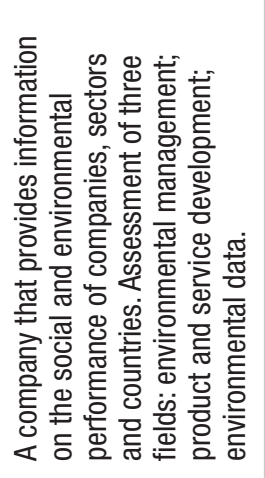 & 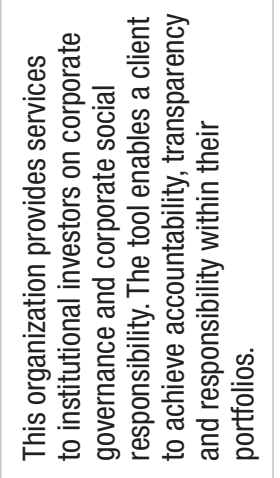 & 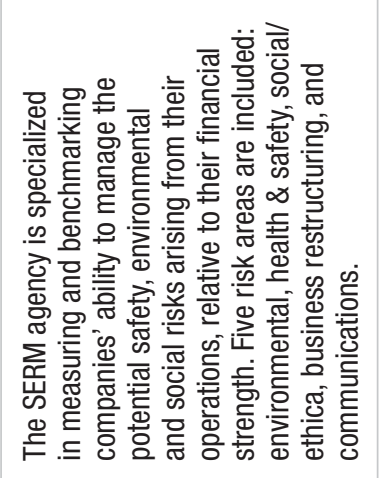 & 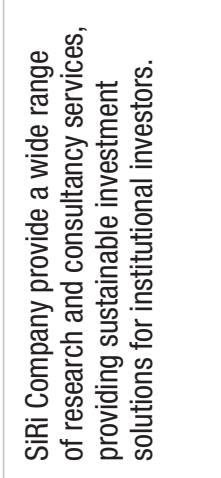 \\
\hline & & 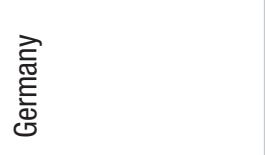 & 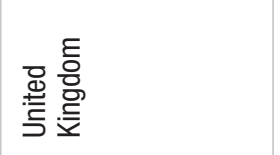 & $\begin{array}{l}\text { 흠 } \\
\text { 产 } \\
\text { 莺 }\end{array}$ & 竞 \\
\hline 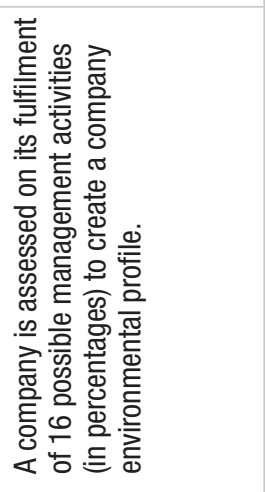 & 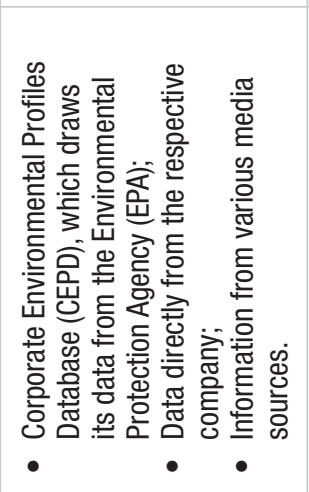 & 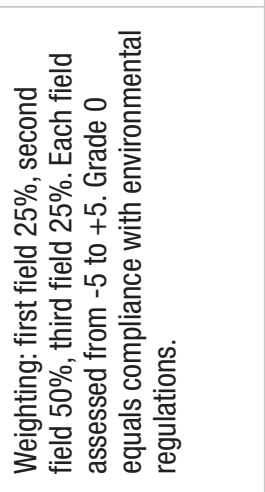 & & 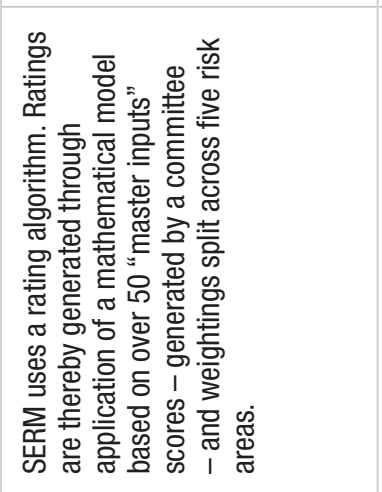 & 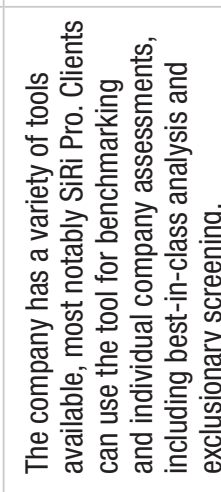 \\
\hline 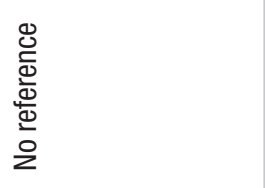 & 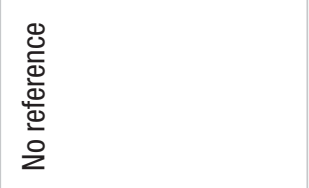 & 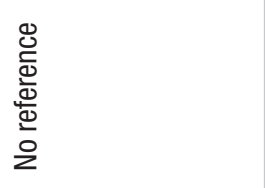 & 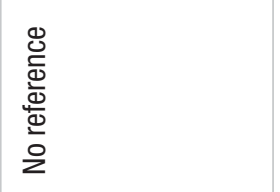 & 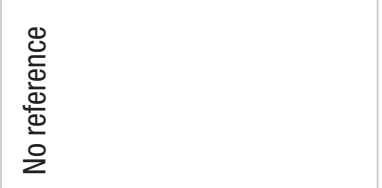 & 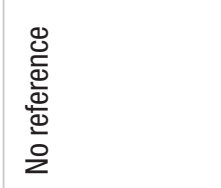 \\
\hline \multirow[t]{2}{*}{0} & • & • & & - & • \\
\hline & & & • & & \\
\hline 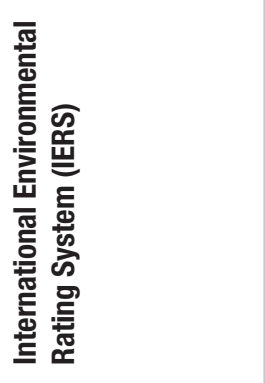 & 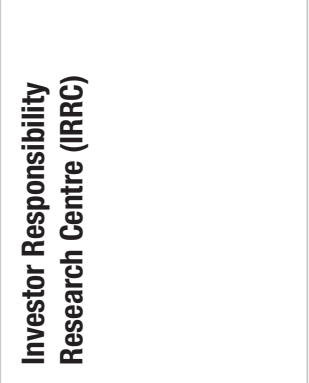 & 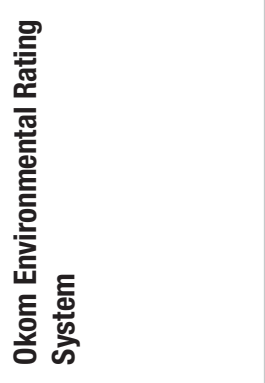 & 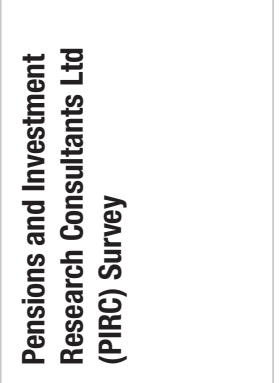 & 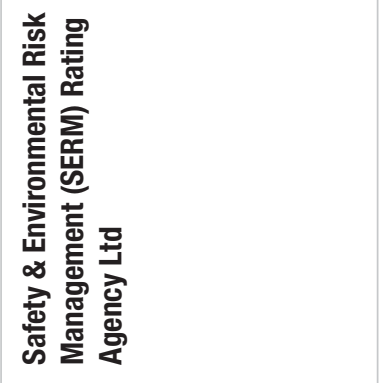 & 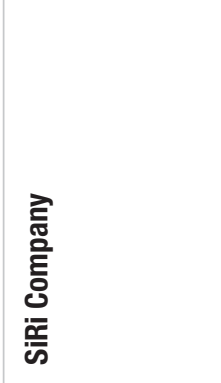 \\
\hline$\stackrel{m}{\longrightarrow}$ & $\stackrel{\nabla}{\square}$ & مص & $\stackrel{\circ}{\circ}$ & 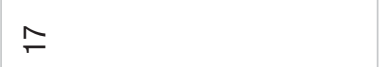 & $\stackrel{\infty}{\stackrel{\infty}{ }}$ \\
\hline
\end{tabular}




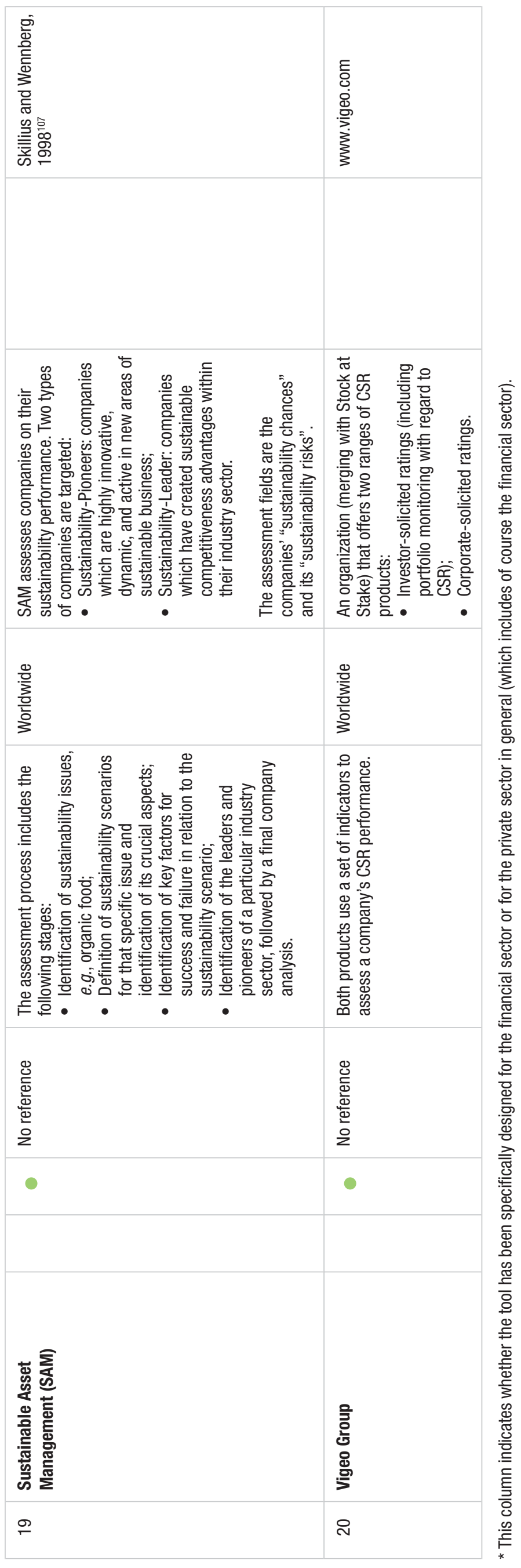




\section{Annex IIla: Questionnaire for financial institutions}

\section{Short project outline}

The last decade has witnessed an emerging number of tools, best-management guidelines, indices and benchmarks that aim to encourage the corporate world, including the financial services sector, to take account of social, environmental and governance issues. A large number of these tools and guidelines address aspects such as climate change, waste and energy use.The issue of biodiversity, however, has only recently started to be addressed. This project aims 1) to provide an overview of the guidelines, management systems, etc that have been developed so far; 2) assess if there is any evidence that biodiversity is a material risk for financial institutions (i.e. a business case); 3) gather opinions on the need/usefulness to develop a biodiversity benchmark and based on these views develop a draft framework which, at a later stage, can be used as a benchmark.

\section{What is meant by "biodiversity"}

Biodiversity is often defined as the diversity within species, between species and of ecosystems (CBD, article 2).Although comprehensive, it might not always be a useful description when communicating with the business community. For businesses, biodiversity would be more useful when defining it as the economic value of natural or 'ecosystem' services that are sustained through the complex simultaneous interaction between many species that has long been integral to economic success, and is now at risk from growing biodiversity loss. ${ }^{\text {www }}$ For the purpose of this report, biodiversity comprises defined ecosystems (i.e. forests, wetlands, drylands, etc) as well as biodiversity-related ecosystem services. ${ }^{\mathrm{xx}}$ It also includes climate-mitigating policies that are focused on (terrestrial or marine) carbon sinks. ${ }^{\mathrm{yy} y}$

\section{Questionnaire:}

1. Does your company have policies in place (e.g., guidelines, codes, principles) that requires screening of investments in new funds/ projects or loans to companies on any biodiversity-related issues (e.g., forestry, wetlands, species impact, climate mitigation ${ }^{3}$ )? Are these policies applied company wide or service specific (e.g., asset management, project finance)? The Equator Principles, for example, have been primarily developed for project finance.

2. Have you/your company come across any evidence that links impacts on biodiversity (either in positive or negative sense) to positive or negative business performance (e.g., in terms of reputation, shareholder value, liabilities, etc)?

3. In your opinion, do you believe there is a business case for biodiversity from the perspective of your company? If so, for what reasons is biodiversity (becoming) a material risk or opportunity?

4. What is your opinion towards developing a biodiversity benchmark:

a. Would it be a useful tool for your company? If so, in what sense? What type of information are you interested in?

b. What departments/units within your company would be most interested?

c. In developing a benchmark, on what type of financial service/activity should it be focused (e.g., investment banking, project finance, hedge funds)?

d. Would you be interested to remain involved with the further development of this benchmark?

Thank you very much for your cooperation! A copy of the report will be send to you! Ivo Mulder (ivo.mulder@fsd.nl).

\footnotetext{
www F\&C Asset Management, 2004. Is biodiversity a material risk for

companies? Timber, fuel wood, genetic resources, and pollination, among others. yyy Insufficient accounting of forests as carbon sinks led to the my Insufficient accounting of forests as carbon sinks led to the Development Mechanism) despite the understanding that $18 \%$ of climate change is due to deforestation.
} 
The last decade has witnessed an emergence of tools, best-management guidelines, indices and benchmarks that aim to encourage the corporate world, including the financial services sector, to take account of social, environmental and governance issues. A large number of these tools and guidelines address aspects such as climate change, waste and energy use. The issue of biodiversity, however, has only recently started to be addressed. This project aims, at first, to review those tools that aim to incorporate biodiversity issues into the business operations of a financial institution (FI). In addition, this questionnaire aims to identify the motivations, needs, gaps and opportunities for FIs to address biodiversity.

1. What toolkits, best-management practice guidelines, indices, etc are you familiar with that try to incorporate biodiversity issues into the strategy, operations and/or activities of companies in the financial services sector?

a. What are they aiming for?

b. To what extent have these tools incorporated biodiversity elements?

c. Has the tool been developed for a specific type of FI sector or for the FI sector in general?

d. In your opinion, which of these tools have most successfully incorporated biodiversity? Why?

2. Is there a business case for "biodiversity" (or ecosystem services) from a FI perspective?

a. If so, what are the needs and motivations from the perspective of the financial services sector towards addressing biodiversity issues? Why?

b. Are there currently SRI funds that incorporate biodiversity issues?

3. What knowledge gaps are there, which deserve particular attention (i.e. what issues have so far insufficiently been dealt with)?

4. In your opinion, what would be the ideal characteristics of a tool with which banks can be screened on addressing biodiversity at various stages of a company's business operation?

a. What indicators should be taken into account?

b. Should this tool be applicable for the banking sector in general or part of the banking sector?

i. Banking products (retail, stocks, hedge funds, etc)

ii. Geographic scope

iii........

c. What other characteristics should such a tool have?

5. What articles, other documents or websites would you suggest to consult?

6. What are key information sources in this field that you suggest? What other experts would you suggest to consult?

Thank you very much for your cooperation and support.A copy of the final report will be send to you! Ivo Mulder (ivo.mulder@fsd.nl). 
${ }^{1}$ G8 Information Centre, 2007. Environment Ministers Agree on a "Potsdam Initiative: Biological Diversity 2010" and Identify a Common Base for Climate Protection. Potsdam, 17 March 2007. Available at http://www.g7.utoronto.ca/environment/env070317-potsdam. htm

${ }^{2}$ Millennium Ecosystem Assessment, 2005. Ecosystems and human well-being: Opportunities and challenges for business and industry. World Resource Institute:Washington DC, USA.

${ }^{3}$ EBI, 2002. Integrating biodiversity conservation into oil \& gas development.Available at the www.theebi.org/products.html

${ }^{4}$ Weber, O, Fenchel, M., Scholz, R.W., in press. Empirical Analysis of the Integration of Environmental Risks into the Credit Risk Management Process of European Banks. Business Strategy and the Environment.

${ }^{5}$ US EPA, 1998. Corporate Environmental Performance as a Factor in Financial Industry Decisions, status report. Environmental Protection Agency, Office of Cooperative Environmental Management NC: New York, USA.

${ }^{6}$ Thompson, P., Cowton, C.J., 2004. Bringing the environment into bank lending: implications for environmental reporting. The British Accounting Review, 36, 197-218.

${ }^{7}$ Weber, O., 2005. Sustainability benchmarking of European Banks and financial service organizations. Corporate Social Responsibility and Environment Management, 12,73-87.

${ }^{8}$ Koellner,T., Weber, O., Fenchel, M., Scholz, R.W., 2005. Principles for sustainability rating of investment funds. Business Strategy and the Environment, 14(1), 54-70.

${ }^{9}$ KPMG, 2005. KPMG international survey of corporate sustainability reporting 2005. KPMG:Amsterdam, The Netherlands.

${ }^{10}$ Foxall, J., Grigg,A., ten Kate, K., 2005. Protecting shareholder and natural value - 2005 benchmark of biodiversity management practices in the extractive industry. FFI and Insight Investment: London, UK.

${ }^{11}$ Equator Principles, 2006. A financial industry benchmark for determining, assessing and managing social and environmental risk in project financing.Available at www.equator-principles.com

${ }^{12}$ UNEP FI, 2006. UNEP FI Biodiversity and Ecosystem Service work stream. Annual General Meeting, October 2006. UNEP FI e-bulletin, issue 54, November-December 2006, p.7.

${ }^{13}$ WWF-UK and Banktrack, 2006. Shaping the future of sustainable finance: Moving from paper promises to performance. WWF-UK and Banktrack: UK.

${ }^{14}$ Corporation of London, 2002. Financing the future - The London Principles. Forum of the Future: London; Department for Environment, Food and Rural Affairs (DEFRA): London, UK.

${ }^{15}$ OECD, 2000. The OECD Guidelines for Multinational Enterprises. Organisation for Economic Co-operation and Development (OECD): Paris, France.

${ }^{16}$ van Schaick, J., Broer,W., Dijkstra, G., 2005. Quick Scan Biodiversity for the food and nutrition sector and the financial sector. CREM; Amsterdam and VBDO; Culemborg, The Netherlands.

${ }^{17}$ UNEP FI, 2006. Finance and Biodiversity Working Session. UNEP Finance Initiatives - World Resources Institute. 28 April 2006, New York.
${ }^{18}$ UNEP FI, 2007. First Group Workshop of the UNEP FI Biodiversity and Ecosystem Services Workstream. 5 April 2007, KPMG: London.

${ }^{19}$ European Environmental Agency, 2001. Business and the environment: current trends and developments in corporate reporting and ranking. European Environment Agency: Copenhagen, Denmark.

${ }^{20}$ Goldman Sachs, 2004. Global Energy: Introducing the Goldman Sachs Energy Environmental and Social Index. London.

${ }^{21}$ Business and 2010 Biodiversity Challenge, 2005. Report of the second Business and the 2010 Biodiversity Challenge meeting. Sao Paulo, Brazil.Available at www.biodiversityeconomics.org

${ }^{22}$ United Nations Convention on Biological Diversity (CBD)

- Article 2. www.biodiv.org

${ }^{23}$ UNEP FI, 2004. The Materiality of Social, Environmental, and Corporate Governance Issues to Equity Pricing. UNEP Finance Initiative: Geneva, Switzerland http://www.unepfi.org/fileadmin/ publications/amwg/amwg_materiality_equity_pricing_report_ 2004.pdf

${ }^{24}$ UNEP FI, 2006. Show me the Money: Linking Environmental, Social and Governance Issues to Company Value. UNEP Finance Initiative: Geneva, Switzerland.

${ }^{25}$ Millennium Ecosystem Assessment, 2005. Ecosystems and Human well-being: Biodiversity synthesis report.World Resources Institute: Washington DC, USA.

${ }^{26}$ FAO, 2005. Global Forest Resources Assessment 2005: Progress towards sustainable forest management. Food and Agriculture Organization: Rome.

${ }^{27} \mathrm{FAO}, 2006$. Spotlight: Livestock impacts on the environment. Food and Agriculture Organization: Rome, Italy.

${ }^{28}$ IPCC, 2007. Climate change 2007: Climate change impacts, adaptation and vulnerability. Summary for policymakers.

${ }^{29}$ Thomas, C.D. et al., 2004. Extinction risk from climate change. Nature, 427, 145-148.

${ }^{30}$ WWF, 2006. Living Planet Report 2006.WWF: Gland, Switzerland; Institute of Zoology: London, UK; and Global Footprint Network: Oakland CA, USA.

${ }^{31}$ S.N., Akçakaya, H.R., Hilton-Taylor, C., Mace, G.M., 2005. Using Red List Indices to measure progress towards the 2010 target and beyond. Phil. Trans. R. Soc. B, 360, 255-268. This figure was adapted by: Bishop, J., Kapila, S., Hicks, F. and Mitchell, P., 2006. Building Biodiversity Business: Report of a Scoping Study. Shell International Limited and the World Conservation Union: London, UK and Gland, Switzerland. (Discussion Draft - October).

${ }^{32}$ Mulder, I., ten Kate, K., Scherr, S., 2005. Private sector demand in markets for ecosystem services: Current status of involvement, motivations to become involved, and barriers and opportunities to upscale involvement. Supplement IV-Mobilizing private sector buyers of ecosystem services. Report to UNDP/GEF on Institutionalizing Payments for Ecosystem Services. Forest Trends and Ecoagriculture Partners: Washington, DC, USA.

${ }^{33}$ Porter, M.E., Kramer, M.R., 2006. Strategy \& Society:The link between competitive advantage and corporate social responsibility. Harvard Business Review, December 2006, 78-92. 
${ }^{34} \mathrm{~F} \& \mathrm{C}, 2004$. Is biodiversity a material risk for companies? An assessment of the exposure of FTSE sectors to biodiversity risk. F\&C Investments: London, UK.

${ }^{35}$ Lascelles, D., 1993. Rating environmental risk. Centre for the Study of Financial Innovations: London, UK.

${ }^{36}$ Lascelles, D., 1997. Personal letter to Åsa Skillius, IIIEE, May 29 1997, Lund, Norway.

${ }^{37}$ Fayers, C., et al., 2000. Environmental considerations in the decision of Australian investment professionals. Journal of Environmental Assessment Policy and Management, 2(2), 173-201.

${ }^{38}$ Case, P., 1996. Land, lending and liability. Chartered Banker, 2(4), 44-49.

${ }^{39}$ Weber, O., Koellner,T., Scholz, R.W., 2003. Nachhaltigkeit im Finanzgeschaeft. Schweizer Personalvorsorge, 01/03, 21-24.

${ }^{40}$ ISIS, 2002. A Benchmarking Study: Environmental Credit Risk Factors in the Pan-European Banking Sector. ISIS Asset Management: London, UK.

${ }^{41}$ EU, 2006. DIRECTIVE 2006/21/EC OF THE EUROPEAN PARLIAMENT AND OF THE COUNCIL of 15 March 2006 on the management of waste from extractive industries and amending Directive 2004/35/EC. Official Journal of the European Union, 11-042006.

${ }^{42}$ See Article 14(2) of the CBD convention text: www.biodiv.org

${ }^{43}$ CBD, 2003. The Cartagena Protocol on Biosafety: A record of the negotiations. CBD, UNEP: Montreal, Canada.

${ }^{44} \mathrm{UN}, 2003$. Protocol on civil liability and compensation for damage caused by the transboundary effects of industrial accidents on transboundary waters to the 1992 Convention on the Protection and use of Transboundary Watercourses and Industrial Lakes and to the 1992 Convention on the Transboundary Effects of Industrial Accidents. http://untreaty.un.org/English/notpubl/27_ 16E.doc

${ }^{45}$ OECD, 2002. OECD Global Forum on International Investment. Conference on Foreign Direct Investment and the Environment: Lessons to be learned from the mining sector. 7-8 February 2002, Paris, France.

${ }^{46}$ EIRIS, 1999. Trustees and ethical investment. The Ethical Investor. http://www.eiris.org/files/public\%20information\%20type\%20publi cations/pensiontrustees99.pdf

${ }^{47}$ ten Kate, K., Bishop, J., Bayon, R., 2004. Biodiversity offsets: views, experiences, and the business case. IUCN: Gland, Switzerland and Cambridge, UK; Insight Investment: London, UK.

${ }^{48}$ Menezes, J., 2007. EU Business and Biodiversity Initiative. Assessing Ecosystems for Business workshop by the World Business Council for Sustainable Development, 19 March 2007, Montreux.

${ }^{49}$ Forbes, 2007. Indigenous people seek millions from Credit Suisse over timer. 3 May 2007. Available at http://www.forbes. com/markets/feeds/afx/2007/05/03/afx3681627.html

${ }^{50}$ Crossley, R., Points, J., 1998. Investing in tomorrow's forests. WWF: Gland, Switzerland.

${ }^{51}$ Environmental Agency, 2004. Corporate Environmental Governance. A study into the influence of Environmental Performance and Financial Performance, full report. Environment Agency: Bristol, UK.
52 Dasgupta, S., Laplante, B., Mamingi, N., 1998. Capital markets responses to environmental performance in developing countries. World Bank:Washington, DC, USA.

${ }^{53}$ WRI, 2003. Mining and critical ecosystems: mapping the risks. World Resources Institute:Washington DC, USA.

${ }^{54}$ WRI, 2005. Changing oil: Emerging environmental risks and shareholder value in the oil and gas industry. World Resources Institute:Washington DC, USA.

${ }^{55}$ Gupta, S., Goldar, B., 2005. Do markets penalize environmentunfriendly behaviour? Evidence from India. Ecological Economics, 52, 81-95.

${ }^{56}$ EIU, 2005. Reputation: risk of risks. Economist Intelligence Unit. (http://store.eiu.com)

${ }^{57}$ Guardian, 29 November 2003. Power driven.Available at http:// www.guardian.co.uk/weekend/story/0,3605,1094541,oo.html

${ }^{58}$ Friends of the Earth, 2004. Barclays and the Karahnjukar project: Exposing the Equator Principles. International Rivers Network (IRN): Berkeley CA, USA; Friends of the Earth (FOE): London, UK.

${ }^{59}$ Birdlife International, 2003. Hydropower development in Iceland: Damage to habitats and species of European importance. Document for information to the Convention on the Conservation of European Wildlife and Natural Habitats. $23^{\text {th }}$ Standing Committee meeting, Strasbourg, 1-4 December 2003.

${ }^{60}$ GRI, 2005. Financial services sector supplement: Environmental performance. Pilot version 1.0. Global Reporting Initiative:Amsterdam, The Netherlands.

${ }^{61}$ UBS, 2007. Risk Management in the Global Wealth Management \& Business Banking. Available at: http://www.ubs.com/1/ e/investors/corporate_responsibility/environment/risk_ management/wmbb.html

${ }^{62}$ EBRD, 2007. Environmental Standards. Available on the EBRD web at: http://www.ebrd.org/enviro/policy/standard.htm

${ }^{63}$ Oxera, 2000.Accounting for the environment: an analysis of the quality of environmental reporting across the food and retail, oil and gas, utilities, and banking sectors. Oxera: Brussels, Belgium and Oxford, UK.

${ }^{64}$ BiTC, 2006. Business in the Community: Environment Index 2005. Business in the Community: London, UK.

${ }^{65}$ Fortune 500, 2006.Available at: http://money.cnn.com/ magazines/fortune/global500/2006/full_list/index.html (2 March 2007).

${ }^{66}$ Sarah Forrest, Goldman Sachs. Interview for project Biodiversity, the Next Challenge for Financial Institutions. January 2007.

${ }^{67}$ Eurosif, 2006. European SRI Study 2006. Eurosif: Paris, France.

${ }^{68}$ Social Investment Forum, 2006. 2005 Report on Socially Responsible Investment Trends in the United States: 10 year review. Social Investment Forum:Washington, DC, USA.

${ }^{69}$ Goldman Sachs, 2005. The growing interest in environmental issues is important for both socially responsible and fundamental investors. Goldman Sachs, Portfolio Strategy: USA.

${ }^{70}$ Derwall, J., Guenster, N., Bauer, R., Koedijk, K., 2005.The EcoEfficient Premium Puzzle. Financial Analysts Journal, 61(2), 51-63. 
${ }^{71}$ Financial Times, 2007. GLG to launch green fund next month. Financial Times, 19 February 2007, p.19.

${ }^{72}$ White,A.L., 2006. Invest, Turnaround, Harvest: Private Equity Meets CSR. Business for Social Responsibility.Available at www.bsr.org

${ }^{73}$ Koellner,T., Weber, O., Fenchel, M., Scholz, R.W., 2005. Principles for Sustainability Rating of Investment Funds. Business Strategy and the Environment, 14, 54-70.

${ }^{74}$ MunichRe, 2007.The many faces of environmental damage. Available at www.munichre.com

${ }^{75}$ OECD, 2002. OECD Global Forum on International Investment. Conference on Foreign Direct Investment and the Environment: Lessons to be learned from the mining sector. 7-8 February 2002, Paris, France.

${ }^{76}$ SwissRe, 2003. Natural catastrophes and reinsurance. SwissRe:Zurich, Switzerland

${ }^{77}$ Financial Times, 2005. True cost of hurricanes still up in the air. Thursday, December 1, 2005.

${ }^{78}$ Walker, C., Way, M., 2004. The heat is on. Global Reinsurance magazine, July/August 2004.

${ }^{79}$ Schweirz, Heck, Zenklusen, Bresch, Schaer,Vidale, Wild, 2006. Modelling European Winter Wind Storm Losses in Current and Future Climate. ETH and SwissRe: Zurich, Switzerland.

${ }^{80}$ Pearce, D., 2002. The insurance industry and the conservation of biological diversity: An analysis of the prospects for market creation. Organisation for Economic Co-operation and Development (OECD): Paris, France.

${ }^{81}$ MunichRe, 2006. Environmental liability: The state as nature's advocate. Available at www.munichre.com

${ }^{82}$ Munich Re, 2000. Perspectives:Today's ideas for tomorrow's world. Munich Re Environmental Magazine 2000, 29-32.

${ }^{83}$ EU Commission, 2004. Directive 2004/35/CE of the European Parliament and of the Council. Official Journal of the European Union, 30 April 2004, L143, 56-75.

${ }^{84} \mathrm{WWF}$ and IUCN 1994. Centres of plant diversity. A guide and strategy for their conservation. 3 volumes. IUCN: Gland, Switzerland and Cambridge, UK.

${ }^{85}$ Assheton Carter, 2007. Personal communication.

${ }^{86}$ TFD, 2003. TFD Review: Forest and Biodiversity Conservation. The Forest Dialogue, 9-11 October 2003, Santa Cruz de Cabralia, Brazil.

${ }^{87}$ HSBC, 2004. Forest Land and Forest Products Sector Guideline. HSBC: London, UK.Available at www.hsbc.com

${ }^{88} \mathrm{~F} \& \mathrm{C}, 2004$. Are extractive companies compatible with biodiversity? Extractive industries and biodiversity: A survey. F\&C Investments: London, UK.

${ }^{89}$ MMSD, 2002. Breaking New Ground: The report of the Mining, Minerals and Sustainable Development Working Group. IIED: London, UK and WBCSD: Geneva, Switzerland.

${ }^{90}$ UNEP, 2001. The UNEP Dams and Development Project.Available at http://www.unep.org/dams
${ }^{91}$ HSBC, 2005. Freshwater Infrastructure Guideline. HSBC: London, UK. Available at www.hsbc.com

${ }^{92} \mathrm{CI}$ and IBLF, 2005. Sustainable Hotel - Siting, Design and Construction. Conservation International and the Prince of Wales International Business Leaders Forum: London, UK.

${ }^{93}$ WTO/UNEP, 2005. Making Tourism more Sustainable - A Guide for Policy Makers. United Nations Environment Programme (UNEP): Paris, France and the World Tourism Organization (WTO), Madrid, Spain.

${ }^{94}$ Bishop, J., Kapila, S., Hicks, F. and Mitchell, P., 2006. Building Biodiversity Business: Report of a Scoping Study. Shell International Limited: London, UK and IUCN: Gland, Switzerland. (Discussion Draft - October)

${ }^{95}$ Lambe, 2007. The New Eco-Warriors: Can markets succeed where tree-huggers failed? The Banker, 8 January 2007, p.32.

${ }^{96}$ IFC, 2003. Beyond Risk. International Finance Corporation: Washington, DC, USA.

${ }^{97}$ Stern Review on the Economics of Climate Change, 2006. This review was presented by Sir Nicholas Stern, Head of the Government Economics Service and Advisor to the Government on the economics of climate change and development, October 2006.

${ }^{98}$ Hockerts, K., 2001. What Does Corporate Sustainability Actually Mean from a Business Strategy Point of View? INSEAD, Fontainebleau, France

${ }^{99}$ Trevor, L, Wollin, A., Lafferty, G., 2001. Achieving social responsibility through corporate strategy: a matter of governance. Southern Cross University: Lismore, NSW. and University of Queensland:Australia.

${ }^{100}$ Wikipedia, consulted April 2007. http://en.wikipedia.org/wiki/ Ecosystem

${ }^{101}$ Wikipedia, consulted April 2007. http://en.wikipedia.org/wiki/ Habitat_(ecology)

${ }^{102}$ Wikipedia, consulted April 2007. http://en.wikipedia.org/wiki/ Non-timber_forest_products

${ }^{103}$ Wunder, S. 2005. Payments for Environmental Services: Some nuts and bolts. CIFOR Occasional paper No. 42. Centre for International Forestry Research (CIFOR): Jakarta, Malaysia.

${ }^{104}$ UNWCED, 1987. Our Common Future. Report of the Brundtland Commission on Environment and Development. Oxford University Press: Oxford, UK

${ }^{105}$ Freeman, E.R., 1984. Strategic Management: a Stakeholder Approach. Pitman: New York, USA.

${ }^{106}$ EarthWatch, 2001. Measuring biodiversity performance Context for questions relating to biodiversity in the Business in the Environment Index of Corporate Environmental Engagement: Oxford, UK

${ }^{107}$ Skillius,A.,Wennberg, U., 1998. Continuity, Credibility and Comparability: Key challenges for corporate environmental performance measurement and communication. European Environment Agency: Copenhagen, Denmark.

${ }^{108}$ Leipziger, 2003. The Corporate Responsibility Code Book. Greenleaf: Sheffield, UK 



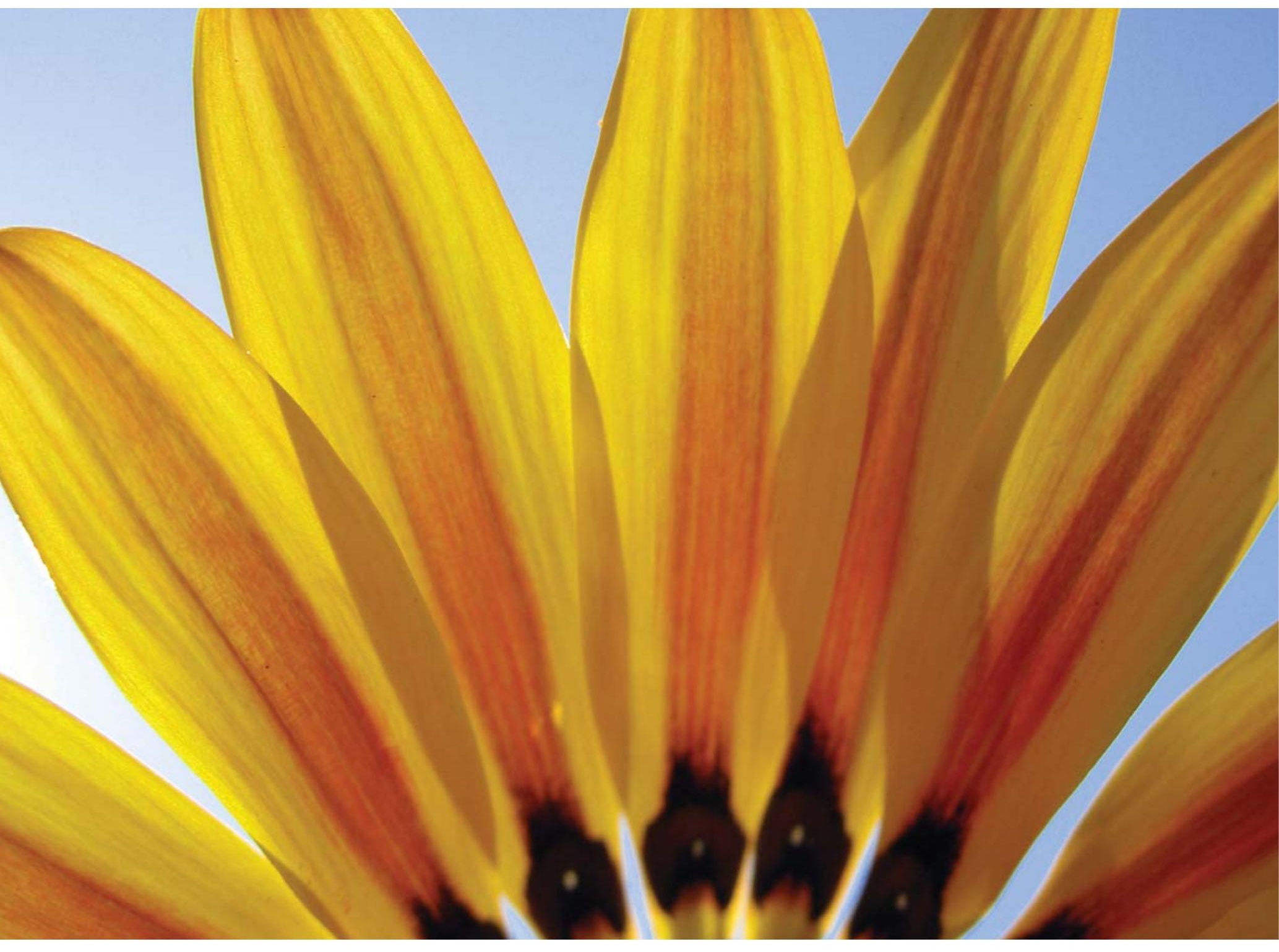

Rue Mauverney 28

1196 Gland

Switzerland

Tel +41229990000

Fax +4122 9990002

mail@iucn.org

www.iucn.org

World Headquarters 